HILDENÊR NOGUEIRA DE LIMA E SILVA

\title{
VARIABILIDADE GENÉTICA DA PROTEÍNA SH (SMALL HYDROPHOBIC PROTEIN) DO VÍRUS SINCICIAL RESPIRATÓRIO HUMANO ISOLADO DE CRIANÇAS NA CIDADE DE SÃO PAULO
}

Tese apresentada ao Instituto de Ciências Biomédicas da Universidade de São Paulo, para obtenção do Título de Doutor em Ciências (Microbiologia).

São Paulo

2009 


\title{
VARIABILIDADE GENÉTICA DA PROTEÍNA SH (SMALL HYDROPHOBIC PROTEIN) DO VÍRUS SINCICIAL RESPIRATÓRIO HUMANO ISOLADO DE CRIANÇAS NA CIDADE DE SÃO PAULO
}

\author{
Tese apresentada ao Instituto de Ciências \\ Biomédicas da Universidade de São Paulo, \\ para obtenção do Título de Doutor em \\ Ciências.
}

Área de Concentração: Microbiologia

Orientador: Prof. Dr. Klaus Eberhard

Stewien

São Paulo

2009 
DADOS DE CATALOGAÇÃO NA PUBLICAÇÃO (CIP)

Serviço de Biblioteca e Informação Biomédica do

Instituto de Ciências Biomédicas da Universidade de São Paulo

() reprodução total

Silva, Hildenêr Nogueira Lima.

Variabilidade genética da proteína SH (Small hydphobic protein) do vírus sincicial respiratório humano isolado de crianças na cidade de São Paulo / Hildenêr Nogueira Lima Silva. -- São Paulo, 2009.

Orientador: Klaus Eberhard Stewien.

Tese (Doutorado) - Universidade de São Paulo. Instituto de Ciências Biomédicas. Departamento de Microbiologia. Área de concentração: Microbiologia. Linha de pesquisa: Virologia clínica molecular.

Versão do título para o inglês: Genetic variability of protein SH of human respiratory syncytial virus (HRSV) of samples collected from children.

Descritores: 1. Glicoproteinas G e SH 2. Seqüenciamento de gene $G$ e SH 3. Vírus sincicial respiratório 4. Pneumovirus 5. Variabilidade genética 6. Vírus RNA I. Stewien, Klaus Eberhard II. Universidade de São Paulo. Instituto de Ciências Biomédicas. Programa de PósGraduação em Microbiologia III. Título. 
Candidato(a): $\quad$ Hildenêr Nogueira de Lima e Silva

Título da Tese: $\quad$ Variabilidade genética da proteína SH (Small hydrophobic protein) do vírus sincicial respiratório humano isolado de crianças na cidade de São Paulo.

Orientador(a): $\quad$ Dr. Klaus Eberhard Stewien

Tese de Doutorado, em sessão

A Comissão Julgadora dos trabalhos de Defesa da pública realizada a considerou

\section{( ) Aprovado(a) \\ ( ) Reprovado(a)}

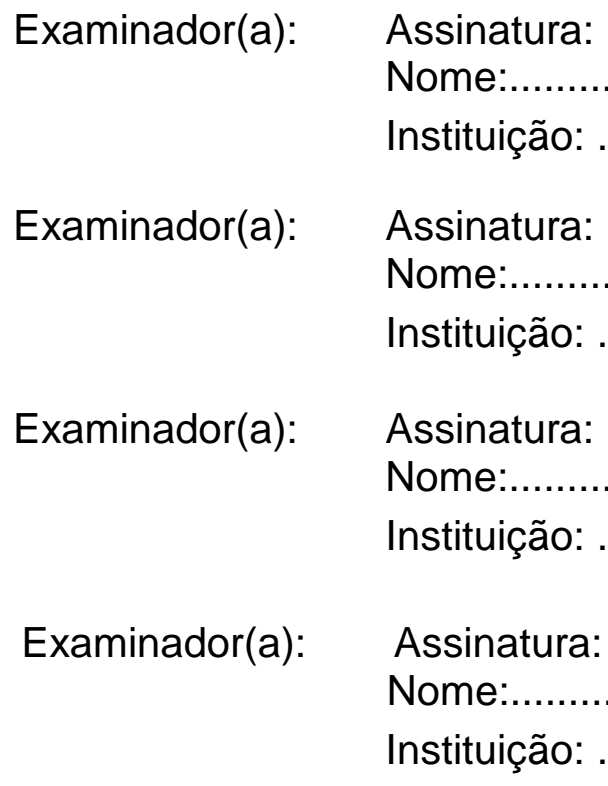

Presidente: Assinatura:

Nome:

Instituição: 
Prezada Senhora,

São Paulo, 30 de maio de 2005.

\section{PARECER 650/CEP}

Atendendo sua solicitação a Comissão de Ética em Pesquisas com Seres Humanos do $I C B$, em sua qüinquagésima quinta reunião, realizada no dia 25maio-2005, analisou o projeto de sua responsabilidade intitulado: "Variabilidade genética da proteína SH (Small Hydrofobic protein) do Virus Respiratório Sincicial de amostras colhidas no Estado de São Paulo”.

Informo a V.Sa. que, após análise e discussão, o referido projeto foi aprovado por esta Comissão, com a recomendação de que no Termo de Consentimento Livre e Esclarecido já aprovado, o item 3 que trata das coletas, seja alterado de forma a não incluir o texto apenas para este estudo. Tendo em mente que a identidade e o material genético do voluntário devem ser protegidos.

Esclareço a V.Sa. que dentro de 12 meses, relatório do referido projeto deverá ser encaminhado à Secretaria deste CEP.

Atenciosamente,

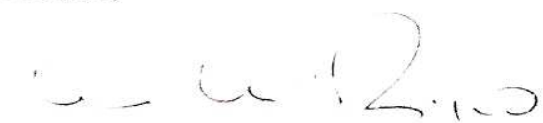

Prof. Dr. Luiz Vicente Rizzo

Coordenador da Comissão de Ética em

Pesquisas com Seres Humanos - ICB /USP

Ilma. Sra.

HiLdENER NOGUEIRA DE LIMA E Silva

Departamento de Microbiologia

Instituto de Ciências Biomédicas -USP

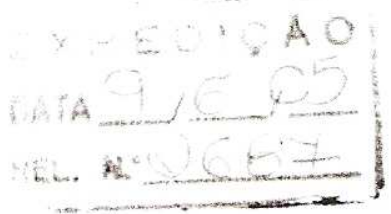

Comissão de Ética em Pesquisa com Seres Humanos do Instituto de Ciências Biomédicas / USP Aprovada pela Comissão Nacional de Ética em Pesquisa - CONEP, em 10 de fevereiro de 1998. 


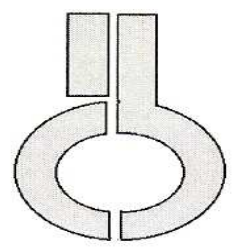

UNIVERSIDADE DE SÃO PAULO INSTITUTO DE CIÊNCIAS BIOMÉDICAS

Cidade Universitária "Armando de Salles Oliveira"

Av. Prof. Lineu Prestes, 2415 - cep. 05508-000 São Paulo, SP - Brasil

Telefone: (55) (011) 38130900 - telefax: (55) (011) 3818-7438

e-mail: icbsedir@icb.usp.br

Decl. CEPSH. 040.09

\section{E C L A R A Ç Ã O}

Em adendo ao parecer 650/CEP, de 25.05.05, informo que o titulo do Projeto foi alterado para "Variabilidade genética da proteína sh (Small Hydrophobic Protein) do vírus sincicial respiratório humano isolado de crianças na cidade de São Paulo" não apresentando restrições quanto às modificações do projeto, que as mesmas não afetam os aspectos éticos da pesquisa.

São Paulo, 04 de maio de 2009.

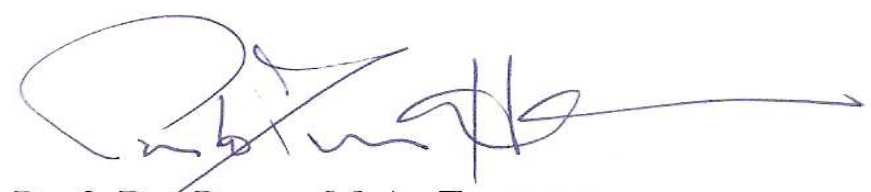

Prof. Dr. PaOlo M.A. ZanotTo

Vice-Coordenador da Comissão de Ética em

Pesquisas com Seres Humanos - ICB /USP

Comissão de Ética em Pesquisa com Seres Humanos do Instituto de Ciências Biomédicas - USP Aprovada pela Comissão Nacional de Ética em Pesquisa - CONEP, em 10 de fevereiro de 1998. 


$$
x^{a}
$$


Aos meus pais Jose Isidio e Virginia, que sempre me incentivaram e apoiaram em todas as decisões e projetos da minha vida.

Ao meu querido esposo Claudionor por seu apoio constante em todos os momentos, paciência sem limite para comigo. 


\section{AGRADECIMENTOS}

Á Deus, pelo seu infinito amor e presença constante em todos os momentos da minha vida, $e$ permitir mais essa conquista em minha vida.

Ao Prof. Dr. Klaus, pelo tempo, e disponibilidade para me aceitar como sua aluna.

Ao Prof. Dr. Edison Luiz Durigon pela orientação, amizade e por ter me dado todo apoio necessário, muitos momentos de diversão, por ser um profissional brilhante e ainda assim ser um ser humano tão adimirável, pelo seu incetivo, por respeitar nossas limitações intelectuais e por ter confiando em meu interesse intelectual e profissional, orientando nossa pesquisa de maneira excepcional, pacienciosa, firme e transparente. E principalmente por acreditar que eu seria capaz de realizar este trabalho.

Ao Prof. Dr. Valério Monteiro, que me ingressou na pesquisa, e despertou em mim o desejo de prosseguir, mesmo quando tudo parecia impossível, pela sua contribuição ao me indicar para estar num centro de excelência em pesquisa como a USP.

A Dra. Maria Luiza Barbosa, pela amizade e contribuição neste trabalho, e pela sua eterna disposição de ajudar os iniciantes na carreira científica.

A Dra. Viviane, pela ajuda inestimável, grande pesquisadora que aprendi a admirá-la, desde que a conheci, seu esfoço e dedicação sempre foram exemplos que me estimularam, nos momentos que achei que as barreiras eram intrasnponiveis, principalmente pelas valiosas sugestões e correções fundamentais na execução deste trabalho.

Aos alunos pesquisadores do Laboratório de Virologia Cliníca e Molecular do ICB II; "Edisolândia: Egma, Luciano Tomazelli, Paty, Angélica, Claudia Trigo, Juliana Nogueira, Zezinho, Lilian, Silvana Favoretto, Cesar Filho, Dayana Lilian Dutra e todos que conviveram comigo durante essa tragetória USPiana, pela amizade, colaboração, pelos momentos de divertimento e por tudo ao longo deste período.

A minha grande amiga Dani Bruna, que me ensinou os primeiros passos em biologia molecular, e por penetrar na minha vida de maneira tão especial, pela amizade, por ter feito parte do meu dia a dia, por termos compartithado momentos e experiências, que guardarei para sempre.

A minha irmã e filha mais velha Ildenir pelo apoio dado, por amar minhas filhas e ajudar-me a cuidar delas, eu jamais confiaria essa tarefa a outra pessoa, meu muito obrigada.

$\mathcal{A}$ meus irmãos que mesmo distantes sempre me apoiaram emocionalmente, em todos meus projetos.

Aos profissionais da secretaria de microbiologia e biblioteca pelo apoio em tudo.

Aos meus amigos e irmãos na fé, Pastor Marcos Ruller, Pastora Gislaine, Walter, Djania, pelas orações e momentos de reflexões.

A minha amiga Diana e seu esposo Ariston pela amizade, e apoio durante esses anos.

Aos meus amigos que em todas as datas comemorativas do ano estivemos juntos; D. Minga, Sr. Ernesto, Wagner, Vartuí, Geovana, Barbára, Pedro, Thomas, Juliana, Dezirré, Júnior Durigon e Isaura, por nos permitir fazer parte dessa famíla maravilhosa (Durigon), amenizando assim a saudade dos meus familiares distantes. ajudar.

Aos pais e crianças internadas, que mesmo em meio ao sofrimento tiveram disposição em

A todos que direta ou indiretamente contribuíram para a realização deste trabalho. 
"Enquanto houver vontade de lutar, haverá esperança de vencer".

Santo Augostinho 


\section{RESUMO}

Silva HNL. Variabilidade genética da proteina sh (Small Hydrophobic Protein) do vírus sincicial respiratório humano Isolado de crianças na cidade de São Paulo [Tese (Doutorado em Microbiologia)]. São Paulo: Instituto de Ciências Biomédicas-Universidade de São Paulo; 2009.

O vírus sincicial respiratório humano (VSRH) é o agente viral mais freqüentemente relacionado a doenças do trato respiratório inferior em crianças abaixo de um ano de idade. Analíse da varibilidade antigênica e gênica mostraram que o VSRH pode ser divido em dois grupos: A e B. O vírus é um membro do gênero Pneumovirus pertencente a família Paramyxoviridea, e possui três principais proteínas que são: glicoproteina $\mathrm{F}$ (fusão), glicoproteina G (adesão), glicoproteina SH (pequena proteína hidrofóbica). A proteína $\mathrm{F}$ é responsável pela fusão da célula ao vírus, enquanto a proteína $\mathrm{G}$ tem papel fundamental na replicação do vírus, porém a função da proteína $\mathrm{SH}$, ainda não está bem definida, estudos recentes mostram-na como responsável por inibir a sinalização do fator de necrose tumoral alfa (TNF- $\alpha$ ). Neste estudo foram colhidas amostras de 965 crianças, entre os anos de 2004 e 2005, dentre as quais 424 foram positivas. 117 amostras foram seqüenciadas a proteína SH e $\mathrm{G}$ e comparadas com amostras que circularam mundialmente. A analíse filogenética mostrou uma baixa variabilidade entre os genótipos estudados tanto do grupo A quanto do B.

Palavras-chave: Vírus Sincicial Respiratório Humano; Glicoproteina $\mathrm{SH}$; Analise Filogenética. 


\begin{abstract}
Silva HNL. Genetic variability of protein sh of human respiratory syncytial virus (HRSV) of samples collected the children in São Paulo City [Ph. D. Thesis (Microbiologia)]. São Paulo: Instituto de Ciências Biomédicas da Universidade de São Paulo; 2009.

The human respiratory syncytial virus (HRSV) is the major cause of lawer respiratory tract infections in infantis, young children and elderly. Analysis of the antigenic and genetic variability has shown that there are two groups of the virus HRSV, A and B. The virus (HRSV) is a member of the genus pneumovirus in the paramyxoviridae family. The virus encodes three membrane-bound glicoproteins, namely the fusion (F) attachment $(G)$ and small hydrophobic $(\mathrm{SH})$ proteins. The F mediates fusion of the virus and cell membranes and the $G$ proteins is involved in virus attachment. The biological properties of the $F$ and $G$ glicoproteins and role that they play during virus replication relatively well understood, however the functional significance of the SH protein during replication remains unclear, although recent study shown that it can inhibit TNF-alpha. In this study, HRSV strains were isolated from nasopharyngeal aspirates collected from 965 children between 2004 and 2005, yielding 424 positive samples. We sequenced the small hydrophobic protein $(\mathrm{SH})$ gene and protein $(\mathrm{G})$ of 117 samples and compared them with other viruses identified worldwide. The phylogenetic analysis showed a low genetic variably among the isolates but allowed us to classify the viruses into different genotypes for the A and B HRSV strains.
\end{abstract}

Key words: Human Respiratory Syncytial Virus. Protein SH; Phylogeentic Analysis. 


\section{LISTA DE ILUSTRAÇÕES}

Figura 1 - Modelo representativo do Vírus Sincicial Respiratório Humano (VSRH).. 21

Figura 2 - Mapa genético do RNA genômico do VSRH.............................................. 22

Figura 3 - Representação esquemática da seqüência gênica do RSV-A2....................... 23

Figura 4 - Eletromicrografias do vírus sincicial respiratório...................................... 29

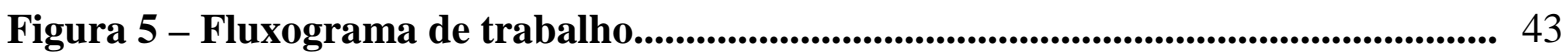

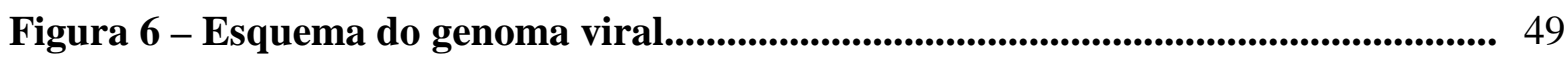

Figura 7 - Sazonalidade das amostras colhidas durante o período de janeiro de 2004

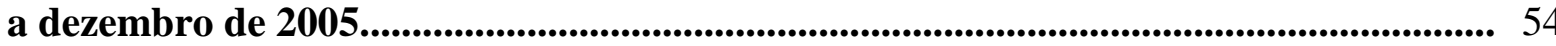

Figura 8 - Distribuição dos genótipos por ano de surtos 2004 e 2005.......................... 56

Figura 9 - Árvore do gene SH grupo A............................................................................... 57

Figura 10 - Árvore do gene SH grupo B.............................................................. 58

Figura 11 - Alinhamento de 195 nucleotìdeos do gene SH de amostras brasileiras de

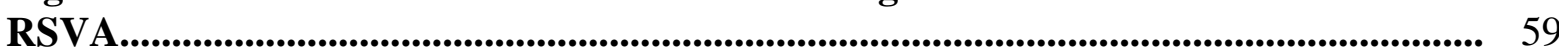

Figura 12 - Alinhamento de 198 nucleotìdeos do gene SH de amostras brasileiras de

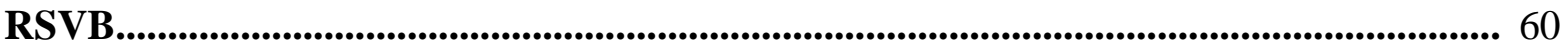




\section{LISTA DE TABELAS}

Tabela 1 - Primers utilizados na amplificação da proteína F do VSRH, para a PCRGeneScan

Tabela 2 - Primers utilizados na PCR, Semi Nested PCR e sequenciamento do gene G do VSRH

Tabela 3 - Distribuição dos genótipos de VSRH, circulantes nos anos de 2004 e 2005 . 


\section{ABREVIATURAS}

aa:

Aminoácido

BRSV: Vírus Sincicial Respiratório Bovino (do Ingl. Bovine respiratory syncytial vírus)

CCA: Agente da coriza do chimpanzé (do ingl. Chimpanzee coryza agent)

cDNA: DNA complementar

DNA: Ácido desoxirribonucléico

dNTP's: $\quad$ Deoxiribonucleosídeos 5'- trifosfatados (dATP, dTTP, dCTP, dGTP) (do ingl. Deoxynucleoside triphosphates).

ECP: $\quad$ Efeito citopático

EDTA: Ácido etilenodiaminotetracético (do ingl. Ethylenediaminetetraacetic acid)

FDA: $\quad$ Serviço de vigilância americano (do ingl. Food and drugs administration)

GAG: $\quad$ Glicosaminoglicano

Gs: $\quad$ GeneScan

GS-RT-PCR: RT-PCR detectado por GeneScan

HSRV: Vírus Sincicial Respiratório Humano (do ingl. Human respiratory syncytial virus)

HU: $\quad$ Hospital Universitário

IFI: Imunofluorescência indireta

Ig: Imunoglobulina

IPAC: Imunoperoxidase anti-complemento

Kb: $\quad 10^{3}$ pares de bases

kDa: $\quad$ Kilodalton $\left(10^{3}\right.$ daltons $)$

M: Molar

Mab: $\quad$ Anticorpo monoclonal (do ingl. Monoclonal antibody)

MEM: $\quad$ Meio mínimo essencial Eagle

min: Minuto

mL: $\quad$ Mililitro $\left(10^{-3}\right.$ litro $)$

mM: $\quad$ Milimolar $\left(10^{-3}\right.$ molar $)$

MP: $\quad$ Máxima parcimônia

MPV: $\quad$ Vírus da peneumonia do camundongo (do ingl. Murine pneumonia vírus)

mRNA: RNA mensageiro

MV: Máxima verossimilhança 


$\begin{array}{ll}\text { Ng: } & \text { Nanograma (10-9 grama) } \\ \text { nm: } & \text { Nanômetros }\left(10^{-9} \text { metro) }\right. \\ \text { nt: } & \text { Nucleotídeos } \\ \text { ORF: } & \text { Fase Aberta de Leitura (do Ingl. Open reading frame) } \\ \text { PA: } & \text { Pronto atendimento } \\ \text { pb: } & \text { Pares de bases } \\ \text { PBS: } & \text { Solução salina tamponada com fosfatos } \\ \text { PCR: } & \text { Reação em cadeia pela polimerase } \\ \text { pg: } & \text { Picograma (10-12 g) } \\ \text { pH: } & \text { Potencial hidrogeniônico } \\ \text { pmol: } & \text { Picomol (10 } 0^{-12} \text { M) } \\ \text { primer: } & \text { Oligonucleotídeo iniciador } \\ \text { q.S.p: } & \text { Quantidade sufuciente para } \\ \text { RNA: } & \text { Ácido Ribonucléico } \\ \text { RNAse: } & \text { Ribonuclease } \\ \text { rpm: } & \text { Rotações por minuto } \\ \text { RT: } & \text { Transcrição reversa } \\ \text { RT-PCR: } & \text { Reação em cadeia pela polimerase após transcrição reversa } \\ \text { SFB: } & \text { Soro fetal bovino } \\ \text { SNP: } & \text { Single nucleic polimorfism } \\ \text { SP: } & \text { São Paulo } \\ \text {-ssRA } & \text { RNA fita simples não segmentado e polaridade negativa } \\ \text { TBE: } & \text { Tampão tris-borato EDTA } \\ \text { TM: } & \text { Temperatura de fusão “Melting Temperature” } \\ \text { Tris: } & \text { Tris (hydroxymethyl) aminomethane } \\ \text { Unidade internacional } \\ \text { Universidade de São Paulo }\end{array}$




\section{LISTA DE SÍMBOLOS}

\section{Aminoácidos}

Alanina

Ala.

A

Asparagina ou ácido aspártico

Asx. B

Cisteína. ..Cys. C

Ácido aspártico.

Asp. .D

Ácido glutâmico

Glu. .E

Fenilalanina

Phe. .F

Glicina.

.Gly. ..G

Histidina.

His. H

Isoleucina. Ile. .I

Lisina. ..Lys. $\mathrm{K}$

Leucina.

.Leu. . L

Metionina. Met. M

Asparagina. Asn. ..N

Prolina. Pro. P

Glutamina. .Gln Q

Arginina Arg. R

Serina. Ser. ..$S$

Treonina. Thr. . T

Valina Val. V

Triptofano. ..Trp. W

Tirosina.. Tyr. Y

Glutamina ou ácido glutâmico

Glx. .Z

\section{Bases nitrogenadas dos nucleotídeos}

Adenina. A

Citosina...... ..C

Guanina G

Timina. T 


\section{SUMÁRIO}

1 INTRODUÇÃ

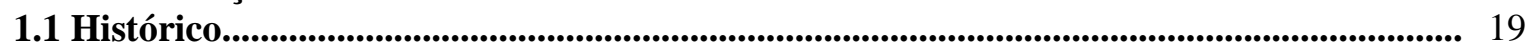

1.2 Organização genômica e características estruturais do VSRH....................................... 20

1.3 Ciclo replicativo do VSRH............................................................................................ 27

1.4 Caracterização antigênica e molecular............................................................................................... 29

1.5 Caracterização Epidmiologica.................................................................................................. 30

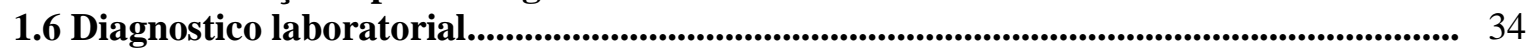

1.7 Profilaxia e tratamento...................................................................................................................... 37

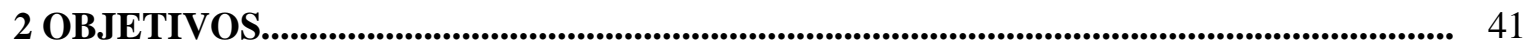

3 MATERIAIS E METODOS............................................................................................. 42

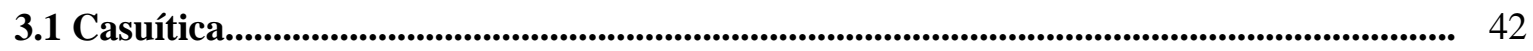

3.2 Diagnóstico do VSRH.................................................................................................................... 44

3.2.1 Colheita das amostras........................................................................................................ 44

3.2.2 Processamento das amostras........................................................................................................ 44

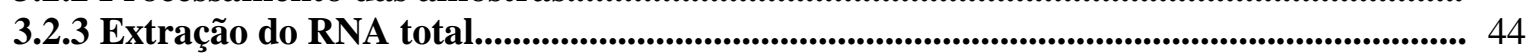

3.2.4 Obtenção do DNA complementar (cDNA)................................................................. 45

3.2.5 Diagnóstico de VSRH por GeneScan RT-PCR...................................................................... 45

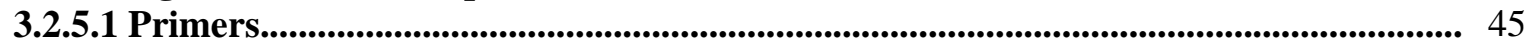

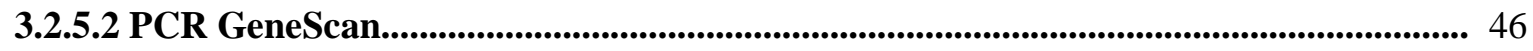

3.2.5.3 Detecção dos produtos amplificados....................................................................................... 46

3.3 Genotipagem do VSRH............................................................................................................. 47

3.3.1 Seleção das amostras para estudo de variabilidade do gene das proteínas G e SH...... 47

3.3.2 Seleção dos primers para o gene G.................................................................................. 48

3.3.3 Amplificaçã̃o da seqüência do gene G............................................................................................. 48

3.3.4 Seleção dos primers para o gene SH......................................................................................... 49

3.3.5 Amplificação da seqüência do gene $\mathrm{SH}$........................................................................... 49

3.3.6 Detecção dos produtos amplificados dos genes G e SH........................................................ 50

3.3.7 Purificação dos produtos amplificados dos genes G e SH................................................ 50

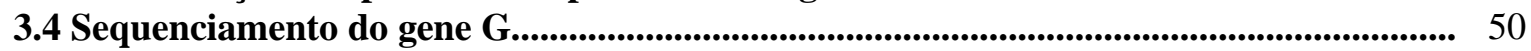

3.5 Sequenciamento do gene SH......................................................................................................... 51

3.6 Alinhamento das seqüências dos genes G e SH....................................................................... 52

3.7 Análise filogenéticas do gene G........................................................................................................ 53

3.8 Análise filogenéticas do gene SH................................................................................................... 53

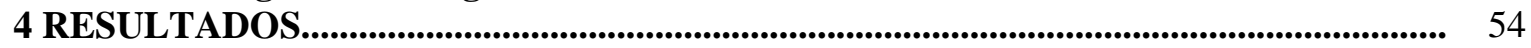

4.1 Circulação e sazonalidade das amostras dos anos de 2004 e 2005................................... 54

4.2 Epidemiologia molecular........................................................................................................... 55

4.2.1 Análise filogenética das amostras circulantes em 2004 e 2005 pela análise do gene G. 55

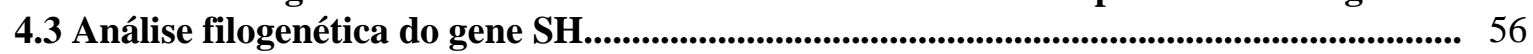

4.4 Sequiências de nucleotídeos e aminoácidos............................................................................ 59

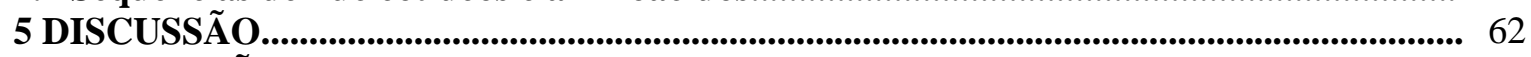

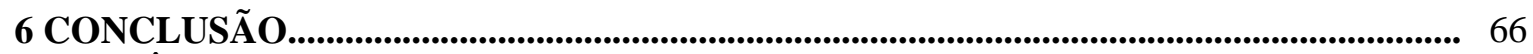

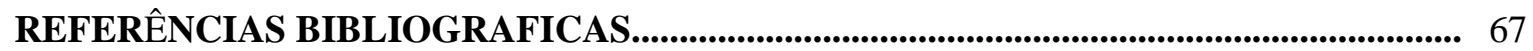

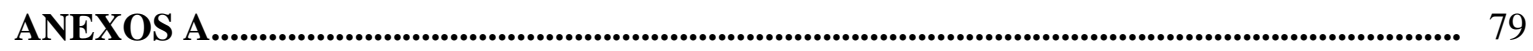

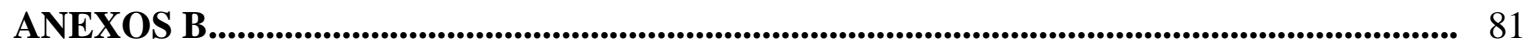

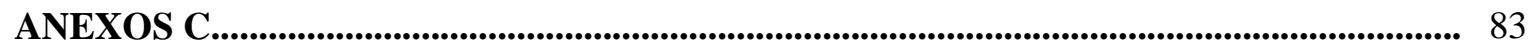

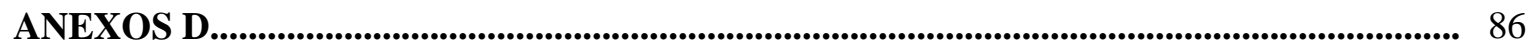

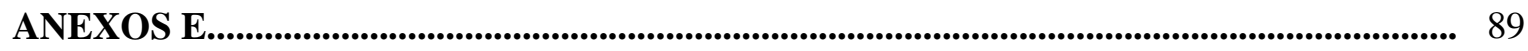

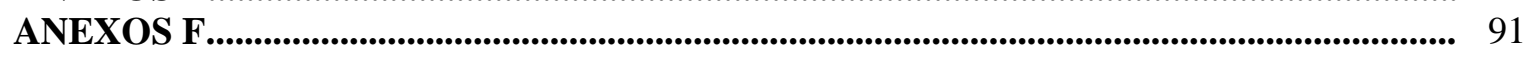




\section{INTRODUÇÃO}

\subsection{Histórico}

O primeiro isolamento do vírus sincicial respiratório humano (VSRH) ocorreu em 1955 a partir de uma amostra clínica swab de orofaringe, de um chimpanzé fêmea, o qual apresentava sintomas semelhantes ao resfriado comum, sendo por isso denominado de agente da coriza do chimpanzé (Chimpanzee coryza agent - CCA). O material isolado foi posteriormente inoculado em cultura de células hepáticas, sendo observadas a degeneração e morte celular. Foram feitas inoculações experimentais em outros animais tais como camundongos, hamsters, coelhos, cobaias, porém a única espécie que apresentou sintomatologia clínica foi o chimpanzé (Morris, et al., 1956).

Os primeiros casos observados em humanos ocorreram em 1956, quando o vírus foi isolado de crianças com infecção do trato respiratório inferior (Chanock, et al., 1957). O agente viral, devido à sua capacidade de produzir sincícios em culturas celulares e à sua predileção pelo trato respiratório humano, passou a ser denominado vírus sincicial respiratório humano VSRH (Chanock, et al., 1961; Suto e Yano, 1965). No Brasil, o vírus foi isolado pela primeira vez por Candeias em 1964 (Candeias, 1967).

$\mathrm{O}$ vírus sincicial respiratório humano (VSRH) pertence à ordem Mononegavirales, vírus de RNA de fita simples e polaridade negativa (Mono, do grego Monos "único, simples", Nega de "RNA de polaridade negativa, Virales, do latim Virale "vírus"). Pertencente à família Paramyxoviridae, sub-familia Pneumovirinae e gênero Pneumovirus Os gêneros da família Paramyxoviridae são diferenciados pelo diâmetro, número de genes e glicoproteínas de superfície. (van Regenmortel, et al., 2000; Koneman, et al., 2001). O VSRH constitui o principal representante do gênero Pneumovirus, apesar de existirem amostras descritas de RSV bovino (bRSV), caprino, ovino e o vírus da pneumonia do camundongo (Murine Pneumonia Vírus) (van Regenmortel, et al., 2000).

As infecções respiratórias agudas têm sido uma das principais causas de mortalidade em crianças com idade de até cinco anos (Bryce, et al., 2005), e o VSRH é considerado um dos principais causadores de infecções do trato respiratório inferior, principalmente em bebês e crianças nos primeiros dois anos de vida, sendo que o pico de incidência ocorre nos primeiros meses de vida (Anderson, et al., 1990; Vieira, et al., 
2001; Kaplan, et al., 2008). O vírus acomete todas as faixas etárias e reinfecções são comuns durante toda a vida, embora os sintomas em crianças na fase pré-escolar e em adultos sejam menos graves. Pacientes imunocomprometidos, em particular aqueles submetidos a transplantes da médula óssea e idosos são considerados pacientes de risco (Collins, et al., 1996; Falsey, 1998; Falsey e Walsh, 2000 Walsh, et al., 2004).

O período de incubação do VSRH é de 3 a 5 dias e os sintomas clínicos podem variar desde um resfriado comum até pneumonias e bronqueolítes (Wyde, 1998; Mcintosh, 1987; Mcintosh e Chanock, 1990). A transmissão ocorre por contato direto com as secreções, via aerossol e, mais frequentemente, por meio de objetos contaminados. O VSRH pode se manter estável por até 6 horas em várias superfícies, sendo muito infeccioso quando aplicado diretamente nas mucosas dos olhos e do nariz, por mãos ou objetos contaminados (Tristram e Welliver, 1996). O mecanismo de infecção inicia-se com a replicação viral nas células do trato respiratório, causando destruição do epitélio, edema e aumento de produção de muco. Após o período de incubação ocorrem as primeiras manifestações clínicas, começando com um resfriado comum, secreção nasal clara, tosse moderada, febre baixa, espirros, peito congestionado. A doença, em alguns casos, evolui para um quadro mais grave, com sintomas de pneumonia ou bronquiolite, levando à hospitalização. (Collins e Graham, 2008). O VSRH por ser um importante agente de infecções nasocomiais, pode atingir até $47 \%$ dos neonatos em berçário e em enfermarias sendo responsável por até $90 \%$ das hospitalizações de crianças até 2 anos de idade (Collins e Graham, 2008).

\subsection{Organização Genômica e Características Estruturais do VSRH}

O virion é pleomórfico envelopado de simetria helicoidal e seu diâmetro varia entre 150 a $300 \mathrm{~nm}$. O envelope é formado por uma bicamada lipídica, que tem origem na membrana citoplasmática da célula hospedeira. Possui espículas correspondentes às glicoproteínas de origem viral, que formam projeções de 11-20 nm, separadas por intervalos de 6-10 nm. A Figura 1 mostra um modelo representativo do vírus. 


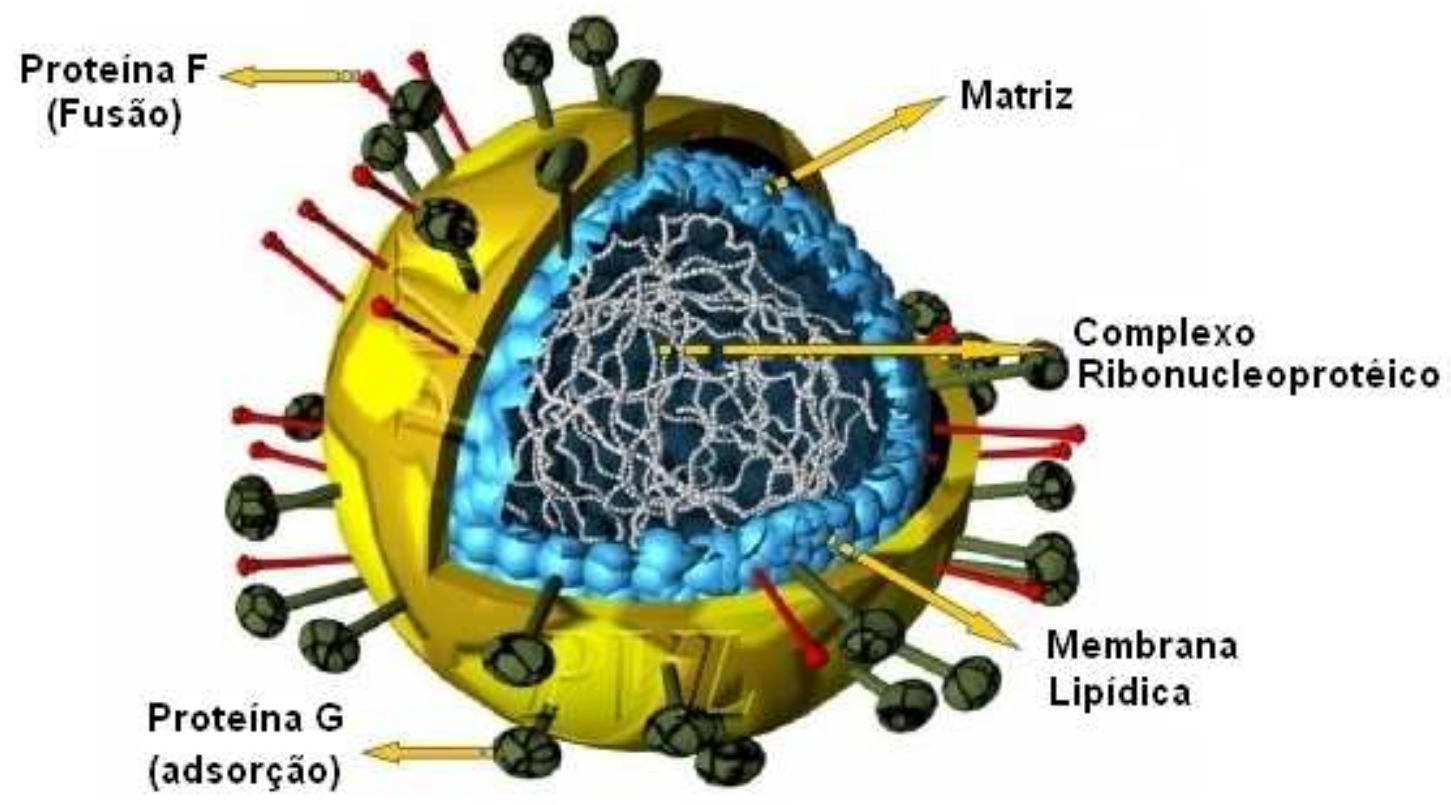

Figura 1 - Modelo representativo do Vírus Sincicial Respiratório Humano ("The Big Picture Book of Viruses") acessado em 07/05/2008 e disponível em http://www.virology.net/Big_Virology/BVRNApara.html

O genoma viral consiste de um RNA de fita simples, com polaridade negativa, não segmentado, contendo 15.222 nucleotídeos. Cada partícula infecciosa contem uma cópia funcional do genoma, com peso molecular de aproximadamente $5 \times 10^{3} \mathrm{kDa}$ (Huang e Wertz, 1982; Collins, et al., 2001; Welliver, 2003). E que serve como modelo para transcrição de 10 RNAs mensageiros (mRNA), os quais codificam 11 proteínas.

A transcrição do genoma se processa no sentido $3^{\prime} \rightarrow 5^{\prime}$. A região 3' do RNA genômico consiste em uma região extragênica de 44 nucleotídeos onde provavelmente se encontra o promotor viral (Mink, et al., 1991). Os primeiros $30 \mathrm{nt}$ desta região, conhecida como leader, são altamente susceptíveis à inativação pela inserção ou deleção de nucleotídeos. Esta região é seguida por dez genes virais na seguinte ordem: NS1; NS2: N; P; M; SH; G; F; M2; e L (Collins, et al., 2001). O número de mRNA diminui à medida que aumenta a distância do promotor. $\mathrm{O}$ gene $\mathrm{L}$ está seguido de uma região extragênica, conhecida como trailer de 155 nt, que é mais tolerante à inserção ou deleção de nuceotídeos (Mink, et al., 1991). Cada gene começa com um sinal conservado de início do gene (gene-star signal) composto por nove nucleotídeos cuja seqüência é 3' - CCCGUUUA, exceto para o gene L que apresenta as seguintes diferenças em negrito ( $3^{\prime}$ - CCCUGUUUUA). O término de cada gene ocorre com um sinal semi conservado (gene-end-signal) composto por 12-13 nucleotídeos cuja 
seqüência é 3'-UCA ${ }_{\mathrm{U}}^{\mathrm{A}} \mathrm{UN}_{\mathrm{UUU}}^{\mathrm{AAA}} \mathrm{UUU}$ - que direciona o final da transcrição e a poliadenilação (Collins, et al., 2001).

Os nove primeiros genes não apresentam sobreposições e são separados por regiões intergênicas que para a linhagem $\mathrm{A} 2$, variam de 1 a 52 nt. Os dois últimos genes M2 e L apresentam uma sobreposição de 68 nt. Sendo assim, o sinal do gene L está localizado dentro do gene M2 bem como o sinal de termino e poliadenilação do gene M2 está localizado dentro do gene L (Figura 2) (Collins, et al., 2001). A figura 2 mostra o esquema do mapa genético do RNA genômico do VSRH, feito com base na linhagem A2.

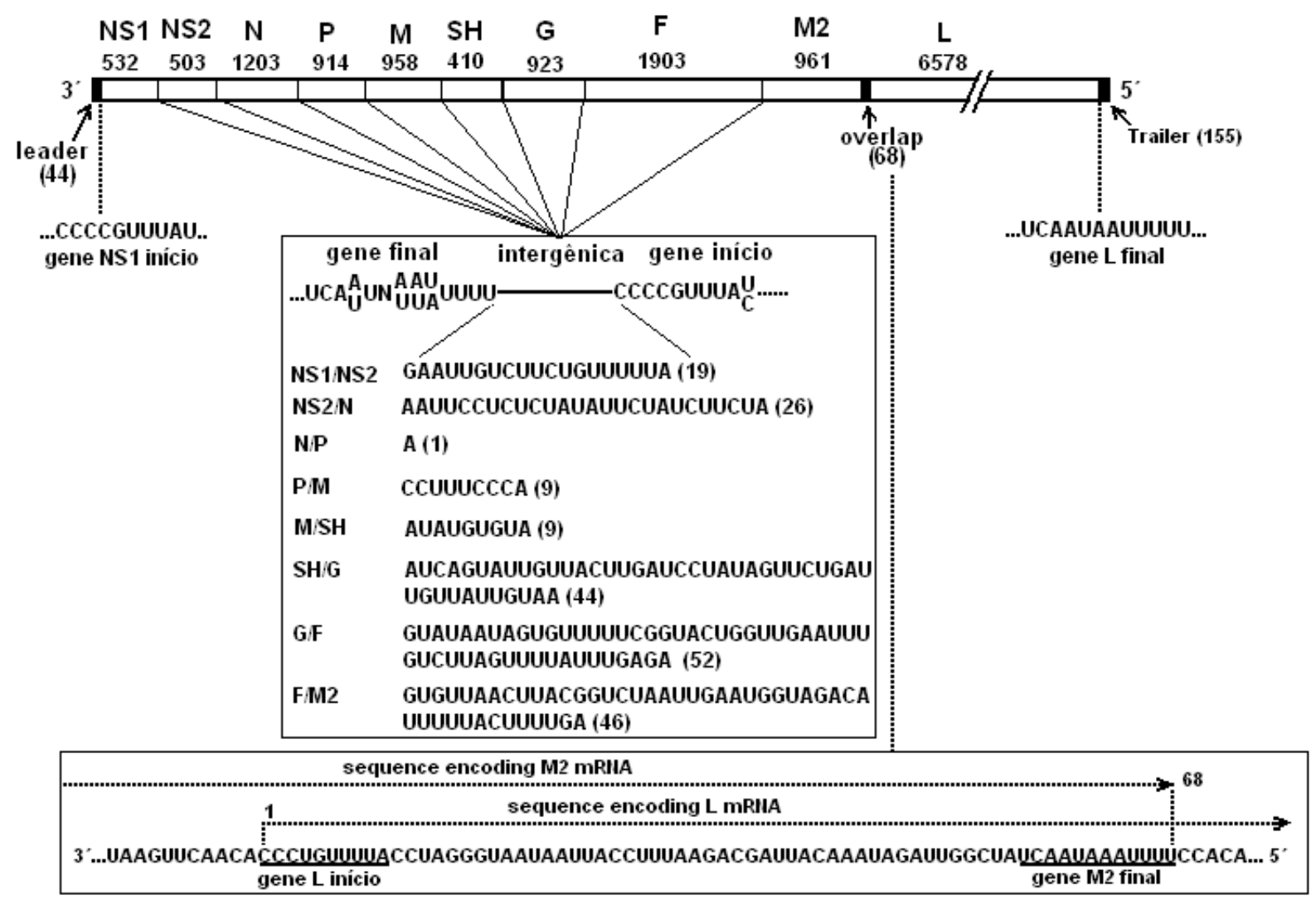

Figura 2 - Mapa genético do RNA genômico do VSRH (Linhagem A2). Os genes são identificados de acordo com a proteína que os codificam (listadas ao longo da parte superior do mapa). Os números abaixo dos nomes de cada proteína correspondem ao tamanho, em nucleotídeos das sequiências apontadas. As duas caixas de texto mostram, em detalhes, as regiões de junções entre os genes (regiões intergênicas) e a região de sobreposição entre os genes M2 e L (overlap). Extraído de Collins, et al., 2001. 
No VSRH foram identificadas nove proteínas estruturais e duas não estruturais (Figura 3). Das proteínas estruturais três são conhecidas como glicoproteínas de superfície: proteína F (Fusão), a G (adesão) e a SH (Small Hydrofobic Protein ) (Collins e Graham, 2008).

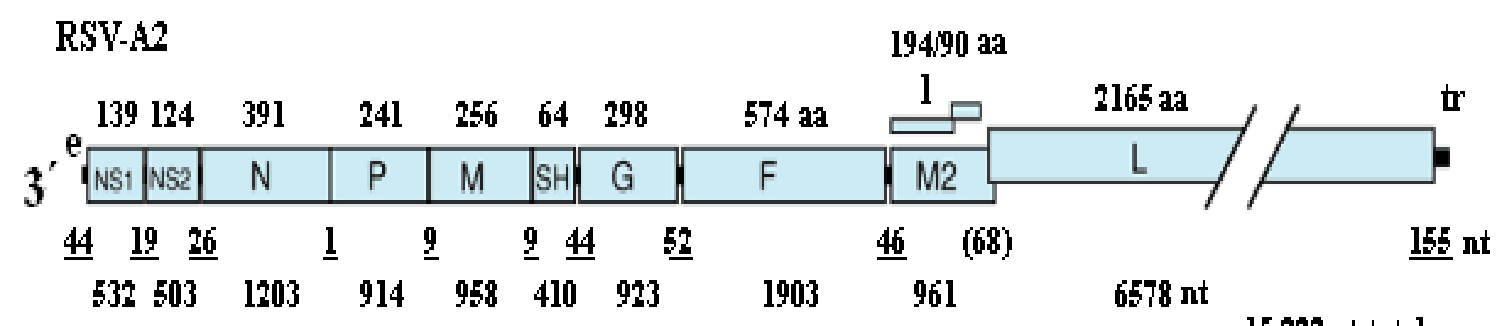

Figura 3 - Representação esquemática da seqüência gênica do RSV-A2 (Fields Virology, Fifth edition.v.1; Edited by B. N. Fields, D. M. Knepe, P. M. Howley, et al. Lippin Cott - Raven Publishers, Philadelphia. p 1610. 2007).

A glicoproteína de fusão (F) é uma proteína tipo I. Foi identificada por Walsh e Hruska (1983). Possui 574 aminoácidos, seu peso molecular é de 70 KDa e o gene que a codifica possui 1903 nucleotídeos. Esta proteína é responsável pela ligação do envelope viral com a membrana plasmática da célula hospedeira, liberando um nucleocapsídeo diretamente dentro do citoplasma, proporcionando a penetração do vírus na célula infectada com uma adjacente, tendo como consequência a formação de sincícios (Collins e Graham, 2008). Esta proteína é sintetizada como precursor inativo $\mathrm{F}_{0}$ que consiste em dois domínios $\mathrm{F}_{2}$ (aminoácidos 1 a 130), e do domínio $\mathrm{F}_{1}$ (aminoácidos 137 a 574) e de um peptídeo de clivagem (aminoácidos 131 a 136). (Bolt, et al., 2000; Rixon, et al., 2002). Após a síntese e a glicosilação a proteína $\mathrm{F}$ é clivada proteoliticamente por uma protease celular, semelhante à tripsina, em duas subunidades $\mathrm{F}_{2}$ cujo peso molecular é $20 \mathrm{KDa}$ e $\mathrm{F}_{1}$ com peso molecular $68 \mathrm{KDa}$, que permanecem ligadas por pontes dissulfeto (Matthews, et al., 2000). A subunidade $\mathrm{F}_{1}$ é relativamente bem conservada, sendo sua função comprometida mediante deleções ou substituições de aminoácidos (Collins e Graham, 2008).

Um estudo sobre interação das proteínas $\mathrm{F}, \mathrm{G}$ e $\mathrm{SH}$, sugeriu que as proteínas $\mathrm{F}$ e G formam um complexo na superfície das células infectadas pelo VSRH, porém não encontrou nenhuma evidência de que as três proteínas juntas formem um complexo. 
Apesar de os mecanismos que levam à fusão de membrana em células infectadas ainda não serem bem entendidos, as associações entre as proteínas G e F encontradas nesse estudo sugerem que a proteína $\mathrm{G}$ tem papel indireto no processo de fusão. (Low, et al., 2008).

A glicoproteína de adesão (G) é uma glicoproteína do tipo II, possuindo uma seqüência não clivável do tipo sinal-âncora próxima à porção amino-terminal, sendo que a porção carboxi-terminal é externa à membrana (Collins, et al., 2001; Collins e Graham, 2008). O sinal-âncora constitui uma região hidrofóbica (aminoácidos 38 a 66 responsáveis pela ancoragem da proteína no envelope viral (Mcintosh e Chanock, 1990). Possui 289 a 319 aminoácidos, dependendo da amostra viral. O gene que a codifica possui, em geral 918 nucleotídeos (grupo A) e varia de 920 a 980 nucleotídeos para o grupo B (Johnson, et al., 1987; Collins, et al., 2001; Trento, et al., 2003; Zlateva, et al., 2004). A glicoproteína G é sintetizada como uma proteína de peso molecular de $33 \mathrm{KDa}$, sendo posteriormente glicosilada para a obtenção da sua forma madura de peso molecular de $90 \mathrm{KDa}$. O ectodomínio carboxila-terminal da proteína G caracteriza-se por conter um alto teor de serina e treonina (31\%), os quais são potenciais sítios de ligação para glicídios que fazem ligações $O$-glicosídicas. A proteína apresenta de 24 a 25 cadeias de glicídios $O$-ligados e de 4 a 8 cadeias do tipo $N$ - ligados. A presença de $13 \%$ de prolina contribui para a redução das estruturas secundárias. O grande número de resíduos e de diversas cadeias laterais de glicídios, numa cadeia relativamente pequena de aminoácidos, pode contribuir para a obtenção de uma estrutura estendida, não globular. As espículas da proteína G apresentam-se sob a forma homotrimérica ou homotetramérica (Collins, et al., 2001).

Levine e colaboradores, em 1987, demonstraram, em coelhos que a glicoproteína $\mathrm{G}$ possui função de adsorção, pois os anticorpos contra essa proteína inibiram a ligação do vírus às células hospedeiras. Apesar de não apresentar ação hemaglutinante, a glicoproteína $\mathrm{G}$ é análoga à hemaglutinina de outros vírus da família Paramyxoviridae (Tristam e Welliver., 1996; Sullender, et al., 2000).

Dentre todas as proteínas a mais estudada é a glicoproteína G por apresentar uma região com maior variabilidade entre os isolados virais (Anderson et al. 1985; Mufson, et al., 1988; Gimenez, et al., 1984; Johnson, et al., 1987), podendo ainda suportar inserções e deleções ou múltiplas substituições de aminoácidos sem a perda de sua função (Beeler e Coeling, 1989; Trento, et al., 2003; Sato, et al., 2005; Zlateva, et al., 2004). A variabilidade desta proteína está concentrada no domínio extracelular, 
onde se encontram duas regiões variáveis, que contém alto teor de serina e treonina entre os aminoácidos 69-164 e 207-298, com aproximadamente 56\% de divergência entre as amostras do grupo A e B (Jonhson, et al., 1987) intercalando essa região altamente variável existe uma região mais conservada, com um pequeno segmento de 13 aminoácidos (164-176) e quatro resíduos de cisteína $\left(C^{173}, C^{176}, C^{182}, C^{186}\right)$, conservados em todas as amostras de VSRH (Sanz, et al., 1994; Melleiro, et al., 1997; Sullender, et al., 2000). Acredita-se que este segmento conservado, seja o responsável pela ligação do vírus ao receptor celular e pelo estimulo as Th1 e Th2 (Vargas, et al., 2000). A variabilidade genética da proteína $G$ tem sido largamente estudada e mecanismos de escape do VSRH, vêm sendo elucidados (Sullender, et al., 2000; Arbiza, et al., 2005; Galiano, et al., 2005; Zlateva, et al., 2005, Botosso, et al., 2009).

Recentemente, estudos observaram a inserção de sessenta nucleotídeos no gene da proteína $\mathrm{G}$, fato que confere um aumento de vinte aminoácidos na cadeia peptídica desta proteína. A polimerase do RSV copia repetidamente parte da sequiência do gene da proteína $\mathrm{G}$ como um mecanismo adicional gerando maior diversidade no vírus. Provavelmente, essa inserção confere um aumento da glicolisação na proteína o que pode determinar um aumento da antigenicidade e infectividade do vírus. (Trento, et al., 2003; Nagai, et al., 2004).

A tradução, começando em um códon de iniciação (AUG) alternativo, localizado na região transmembrana (met 48), produz uma forma solúvel da proteína $\mathrm{G}$ conhecida como (Gs). Após a síntese e glicosilação, a proteína sofre clivagem proteolítica para produzir a forma solúvel com a porção terminal correspondendo a Asn66 (Robert, et al., 1994; Sullender, et al., 2000). Aproximadamente 15\% da proteína Gs sintetizadas em células infectadas são secretadas nesta forma (Hendricks, et al., 1988). A função biológica da Gs, no ciclo do vírus, ainda permanece desconhecida, mas parece estar relacionada com a imunopatologia nas infecções. (Graham, et al., 2000).

A proteína SH é uma proteína pequena, hidrofóbica que possui 64 aminoácidos para o grupo A ou 65 aminoácidos para o grupo B, (Chen, et al., 2000) e o gene que a codifica possui 410 nucleotídeos. Esta proteína está ancorada à membrana por um sinalâncora, que é uma seqüência hidrofóbica que vai do aminoácido 14 ao 41 . Sua porção carboxila-terminal é externa à membrana citoplasmática. Nas células infectadas pode estar presente em quatro formas: $\mathrm{SH}_{\mathrm{o}}, \mathrm{SH}_{\mathrm{g}}, \mathrm{SH}_{\mathrm{p}}, \mathrm{SH}_{\mathrm{t}}$, sendo que a $\mathrm{SH}_{\mathrm{o}}$ é a mais abundante e representa a forma não glicosilada de 7,5 $\mathrm{KDa}$. A $\mathrm{SH}_{\mathrm{g}}$, com peso molecular variando de 13 a $15 \mathrm{KDa}$, corresponde ao $\mathrm{SH}_{\mathrm{o}}$ contendo uma cadeia lateral 
oligassacarídeos unidos ligados por ligação glicosídica tipo N. A forma $\mathrm{SH}_{\mathrm{p}}$ é uma versão da forma $\mathrm{SH}_{\mathrm{g}}$ com peso molecular variando de 21 a $40 \mathrm{KDa}$. $\mathrm{A} \mathrm{SH}_{\mathrm{t}}$ é uma forma não glicosilada com peso molecular de 4,8 KDa. A função desta proteína ainda não está elucidada, porém por estar integrada à membrana, supõe-se estar envolvida no processo de adsorção, penetração e desnudamento do vírus (Collins, et al., 2001). Evidências sugerem que a proteína SH pode representar um fator de virulência; não essencial para replicação viral, pois o vírus pode crescer normalmente em cultura de células, inclusive com formação de sincícios, mesmo quando o gene SH é deletado. Entretanto, pode ser um importante fator para a patogenicidade in vivo (Karron, et al., 1997; Bukreyev, et al., 1997).

Fuentes e colaboradores (2007) demonstraram que a proteína SH do VSRH possui função similar à de outras proteínas SH existente nos membros da família Paramyxoviridae, principalmente da parainfluenza 5 (PIV). Esta proteína e responsável por inibir a sinalização do fator de necrose tumoral alfa (TNF- $\alpha$ ) que está associado, entre outras funções, com a sinalização para apoptose de células infectadas por vírus, tendo portanto, um importante papel na inibição da apoptose celular.

A nucleoproteína (N) possui 391 aminoácidos, peso molecular de 43,4 KDa, e o gene que a codifica possui 1203 nucleotídeos, sendo esta a principal proteína do nucleocapsídeo. (Collins, et al., 2001). O RNA genômico e anti-genômico do VSRH encontra-se sempre formando um complexo N-RNA com a proteína $\mathrm{N}$ que é usado como molde para a síntese de RNA. Este complexo proteína N-RNA traz diversos benefícios para o vírus, como prevenir a formação de estruturas secundárias na molécula de RNA, protegendo à mesma de degradação por nucleases e reduzindo a formação de RNAs dupla fita, o que poderia levar a uma resposta celular antiviral (Cowton, et al., 2006).

A proteína large (L), a maior proteína do VSRH, é constituída por 2165 aminoácidos, possuindo peso molecular de $250 \mathrm{KDa}$. e o gene que a codifica possui 6578 nucleotídeos. Esta proteína contém seis segmentos altamente conservados e com possíveis domínios funcionais, (Collins, et al., 1996). Atribui-se a esta proteína as atividades enzimáticas de RNA-polimerase-RNA dependente, além de poliadenilação e formação de estrutura de cap do mRNA viral (Barik., 1993; Manson, et al., 2004).

A fosfoproteína (P) é altamente fosforilada, ácida e está envolvida no processo de transcrição e replicação viral. Possui 241 aminoácidos, peso molecular de $35 \mathrm{KDa}$ e o gene que a codifica possui 914 nucleotídeos (Collins, et al., 2001). A proteína $\mathrm{P}$ 
contém uma subunidade da polimerase viral formada pelas proteínas $\mathrm{P}$ e L e por analogia com outros Mononegavirus, parece mediar o contato entre a proteína L e o complexo proteína N-RNA (Tran, et al., 2007).

As proteínas (M) possuem a função de mediar a associação entre 0 nucleocapsídeo e o envelope viral nascente. As proteínas M 2-1 (PM 22 KDa) e M 2-2 (PM $11 \mathrm{KDa}$ ) são internas e não glicosiladas, possuindo respectivamente 256 e 194 aminoácidos, e o gene que as codificam possuem 958 e 961 nucleotídeos e a sendo a M2-1 responsável pela elongação durante a transcrição (Collins e Graham, 2008). Além de favorecer a passagem da polimerase viral pela região intergênica, facilita o acesso dessa polimerase à unidade final da transcrição (Hardy, et al., 1998). Esta proteína possui essencial função na replicação do VSRH e alterações em sua seqüência podem diminuir a infectividade do vírus (Tang, et al., 2001).

A M2-2 é uma proteína reguladora, envolvida na mudança de transcrição para a replicação do RNA viral durante o ciclo replicativo do vírus (Atreya, et al., 1998; Schimidit, et al., 2001). Essa proteína quando expressa em altos níveis, inibe completamente a replicação do VSRH, sugerindo que esta proteína, quando produzida nas células infectadas em grande quantidade, pode ser um fator crítico na replicação do VSRH (Cheng, et al., 2005).

As proteínas não estruturais são $\mathrm{NS}_{1}(\mathrm{PM} 15,5 \mathrm{KDa})$ e $\mathrm{NS}_{2}(\mathrm{PM} \mathrm{14,6).} \mathrm{Possuem}$ respectivamente 139 e 124 aminoácidos (Collins, et al., 2001). Estão presentes em abundância nas células infectadas porém em pouca quantidade no virion (Cane, et al., 2001). Suas funções ainda não foram definidas, porém supõe-se estarem envolvidas na regulação da transcrição e replicação (Atreya, et al., 1998).

\subsection{Ciclo replicativo do VSRH}

O ciclo replicativo do VSRH começa a partir da ligação do vírus pela proteína de adsorção (proteína $G$ ) á superfície da célula por meio de receptores presentes na membrana da célula hospedeira. O receptor especifico para a glicoproteina $G$ é a heparina ou outro glicosaminoglicano (GAGs) presente na membrana celular (Martinez e Meleiro 2000). A seguir, ocorre a fusão do vírus com a membrana celular mediada pela ação da proteína de fusão que é a proteína $\mathrm{F}$, a qual promove a liberação do nucleocapsídeo viral diretamente no citoplasma celular. Todas as etapas da replicação 
do VSRH ocorrerão no citoplasma sem envolvimento do núcleo celular (Collins, et al., 2001).

O processo de transcrição do genoma viral inicia-se após a liberação do nucleocapsídeo viral no citoplasma celular; ocorre então a transcrição do genoma viral, no sentido 3` a 5’, a partir de um único promotor localizado na terminação 3’. A enzima polimerase RNA dependente adere à região “leader" do genoma, iniciando a transcrição do primeiro nucleotídeo. Na junção da região leader com o primeiro gene (NS1), ocorre a liberação do transcrito e a polimerase recomeça a transcrição de forma sequencial do inicio ao fim guiada pelos sinais de inicio e fim do gene, região "traler". Esse mecanismo resulta na produção de RNAs mensageiro (mRNA) de copias iguais ao gene original sem modificações. Os RNAs são poliadenilados na extremidade 3' e recebe o “cap" que é um nucleosideo guanosina conectado ao RNA pela ligação 5’ trifosfato, na extremidade 5`(Collins e Graham, 2008).

Os mRNAs e as proteínas virais podem ser detectadas intracelularmente de 4 a 6 horas após a infecção. O pico da síntese dos mRNAs ocorre após 16 horas e das proteínas, 18 a 20 horas em média (Collins, et al., 2001). Além dos mRNAs podem-se encontrar em menor quantidades grandes mRNAs poliadenilados. Estes são gerados pela transcrição continua de dois ou mais genes e contem tanto a sequência dos genes quanto a da região intergênica. Aparentemente, em torno de 5\% a $10 \%$ das vezes a polimerase falha no reconhecimento do sinal de fim do gene e continua sintetizando o mRNA até encontrar o próximo sinal (Colinns, et al., 2001).

Adicionalmente á transcrição e a tradução de proteínas, ocorre a replicação do genoma viral que produz uma fita de RNA intermediária possitiva (+ssRNA), a qual servirá como molde para gerar cópias de genoma viral (-ssRNA). A produção do intermediário requer que a maquinaria de produção de mRNAs entre em um modo "anti-terminação", ignorando todos os sinais de início e fim de cada gene, bem como a seqüência leader e o gen NS1 (Kingsbury, 1990; Colinns, et al., 2001)

A princípio a maturação do vírus ocorre pela combinação das proteínas $\mathrm{N}$ e $\mathrm{P}$ com o RNA genômico e subseqüente adição da proteína L. Para a montagem do envelope as glicoproteínas virais ocupam o lugar das proteínas celulares na membrana citoplasmática após serem modificadas por glicosilação, que acontece durante o transporte pelo complexo de golgi. As proteínas da matriz se agregam na porção interna do envelope nascente e o nucleocapsideo alcança a superfície ocorrendo brotamento. $\mathrm{O}$ vírus é liberado levando consigo uma porção da membrana plasmática, num processo 
inverso ao da penetração por fusão, sendo este o momento em que o vírus adquire o envelope lipoprotéico (Kingsbury, 1990).

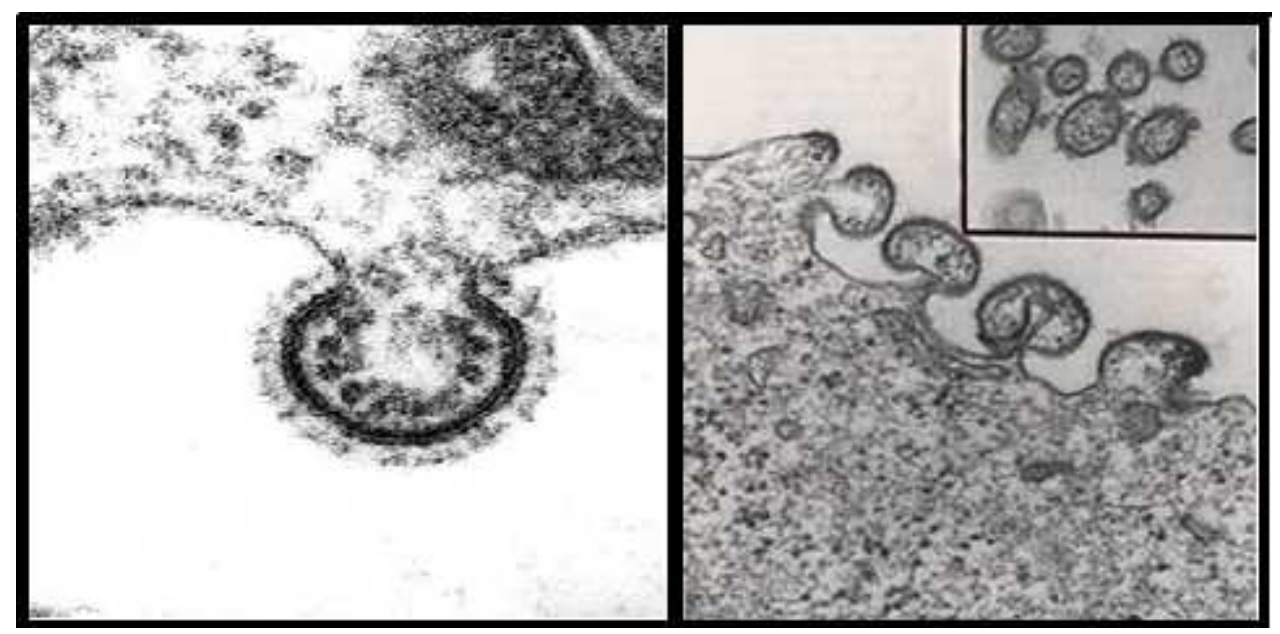

Figura 4 Eletromicrografias do vírus sincicial respiratório (RSV) mostrando alguns vírions em processo de brotamento na membrana celular.

Disponíveis em www.epidemic.org/theFacts/viruses/viralReplication.html e http//www.utmb.edu/utmbmagazine/archive/05 Spring/images/RSV web.jpg acessado em 10/10/2008

\subsection{Caracterização Antigênica e Molecular}

Em 1963, Coates e Chanock foram os primeiros a observar diferenças antigênicas entre duas amostras ao comparar as cepas (A2 e Long) isoladas em 1956 de uma criança com pneumonia. Outras diferenças antigênicas foram observadas em um estudo posterior, entre as amostras (Long e CH18537) isoladas em 1962. Ambos os estudos utilizaram a reação de neutralização cruzada com soro de animal hiperimune (coelhos ou cobaias), demonstrando que a amostra A2 não era neutralizada pelo soro preparado com Long ou CH18537, sugerindo a existência de diferentes variantes cocirculando em uma mesma população (Coates, et al., 1966).

Estudos posteriores, avaliando amostras de diferentes surtos e localidades, confirmaram as diferenças antigênicas entre elas e a existência de diferentes variantes co-circulando pelo mundo. Pesquisas utilizando painéis de anticorpos monoclonais 
permitiram estabelecer a divisão do VSRH em dois grupos antigênicos distintos, denominados A e B. O grupo A está representado pelas amostras $\mathrm{A}_{2}$ e Long e o grupo B pelas amostras CH18537 e Sw8/60 (Anderson, et al., 1985). O padrão de circulação pode ser variável, tanto geograficamente quanto temporalmente sendo entretanto verificada a circulação dos dois grupos em um mesmo surto epidêmico bem como surtos com prevalência do grupo A ou do grupo B (Hendry, et al., 1989; Anderson, et al., 1991; Sullender, et al., 1991).

Atualmente, com base na variabilidade da proteína G, classificam-se os genótipos GA1 a GA7 e SAA1 no grupo A, (Anderson, et al., 1991; Peret, et al., 1998 e 2000, Venter, et al., 2001) e o grupo B, nos genótipos GB1 a GB4, GB6 e GB8, GB10 ao GB13 e SAB1 a SAB3 (Peret, et al., 2000; Venter, et al., 2001; Zlateva, et al., 2005; Gilca, et al., 2006; Zlateva, et al., 2007). Tem-se observado um aumento na variabilidade genética do genótipo GB13, e sua predominância recente na Bélgica implica, provavelmente, sua evolução sobre uma pressão seletiva mais forte do que a dos outros genótipos do VSRH-B (Zlateva, et al., 2007).

Desde 1999, vem sendo relatada, em diversas localidades, a circulação de um novo variante pertencente ao grupo B e conhecido como BA-Like. Esse genótipo caracteriza-se por apresentar uma duplicação de 60 nucleotídeos no gene $\mathrm{G}$ (Trento, et al., 2003; Zlateva, et al., 2004, 2005; Sato, et al., 2005). Outras inserções menores (3 a 6 nucleotídeos) também foram encontradas no Uruguai, Argentina e Japão, demonstrando a ampla variabilidade da proteína G de amostras do grupo B (Kamasaki, et al., 2001; Blanc, et al., 2005).

\subsection{Caracterização Epidemiológica}

O vírus sincicial respiratório é conhecido por sua capacidade de provocar infecções nas vias respiratórias inferiores, sendo responsável por epidemias sazonais bem definidas, com incidência predominante durante o inverno, em climas temperados e durante estações chuvosas em algumas regiões tropicais e subtropicais (Hills, et al., 1971; Collins, et al., 1996), causando um elevado índice de hospitalizações em crianças com até 2 anos de idade (Glezen, et al., 1986; van Schaik, et al., 2000). Infecções causadas por esse patógeno vem aumentando todos os anos, consumindo milhões de dólares em cuidados com saúde (Tekkanat, et al., 2001). A Organização Mundial de 
Saúde estima que o VSRH cause 64 milhões de infecções e que 160 mil pessoas venham a óbito anualmente (Collins e Grahan 2008).

No Brasil, estudos demonstram que as doenças respiratórias agudas (DRAs) são responsáveis por 25 a $50 \%$ das consultas realizadas nos postos de saúde e cerca de 2/3 dos atendimentos de emergência nos hospitais (Sutmoller, et al., 1995). Estudo realizado por Vieira et al. (2001), na cidade de São Paulo, com crianças de 0 a 5 anos, mostrou que a grande maioria das crianças acometidas por esse vírus tinha idade inferior a 3 anos e que o VSRH foi o patógeno viral mais encontrado em crianças com DRA. Na cidade do Rio de Janeiro foi realizado um estudo transversal em 1997 e 1998, segundo o qual o VSRH foi principal causador de infecções virais do trato respiratório inferior (TRI) em crianças internadas (D'Elia, et al., 2005). Em 2003 foi realizado um estudo com oito dos vírus que mais causam DRAs, sendo constatado que a maioria das DRAs são causadas por VSRH (Thomazelli, et al., 2007).

A epidemia do VSRH apresenta sazonalidade bem definida, ocorrendo anualmente no final do outono, inverno ou inicio da primavera, dificilmente ocorre no verão. Cada epidemia dura, aproximadamente, 5 meses sendo que a grande maioria dos casos ocorre durante os meses de pico, normalmente no meio do surto. (Collins, et al., 2001). Países com clima temperado, como Argentina e Paquistão, tem uma sazonalidade semelhante aos países norte americanos e europeus. Já em países de clima tropical é relatado o aumento do VSRH nas estações chuvosas. Diferenças marcantes na sazonalidade do VSRH foram relatadas em regiões geograficamente próximas como Moçambique e África do Sul, ou Bangladesh e Índia, genótipos semelhantes foram encontrados circulando no Brasil e Argentina e Uruguai, demonstrando que a tendência comportamental de uma comunidade pode influenciar na disseminação do VSRH. (Moura, et al., 2004; Girard, et al., 2005; Galiano, et al., 2005).

Zlateva et al. (2007) em um trabalho realizado na Bélgica constatou que a circulação do VSRH ocorre principalmente nos meses de novembro a janeiro com incidência maior no mês de dezembro; porém, foi observada ocorrência nos meses de maio a setembro, sugerindo que este vírus esteja sempre presente e atuando na comunidade continuamente durante todo o ano.

No Brasil, a sazonalidade apresentada pelo VSRH é bastante marcante e similar em diferentes localidades do país como em São Paulo, Fortaleza, Salvador, Uberlândia, nos quais os surtos começam em janeiro ou fevereiro, estendendo-se 
predominantemente, pelo outono-inverno com pico em maio e junho (Viera, et al., 2001; Moura, et al., 2006; Thomazelli, et al., 2007).

O padrão de circulação dos grupos A e B diverge de local para local e de ano para ano. Vários estudos demonstram que os dois tipos tem circulado concomitantemente em muitas epidemias, em diversas regiões do mundo geralmente com a prevalência de um deles. (Anderson, et al., 1991; Botosso, 2002; Zlateva, et al., 2004; Gilca, et al., 2006).

O grupo A é estatisticamente, mais prevalente. Em estudo realizado durante os surtos de 1981 a 1986, no estado da Virginia (EUA), foram analisadas 211 amostras, sendo $76 \%$ grupo A e 24\% grupo B (Mufson, et al., 1988) Em um estudo, englobando os anos de 1978 até 1988, foram analisadas 405 amostras, sendo 79\% do grupo A e 21\% do B, neste estudo o grupo B foi dominante apenas em uma única epidemia (Mufson, et al., 1991). Mais recentemente um estudo com crianças hospitalizadas na cidade de Jordan demonstrou que $70 \%$ das amostras que circularam neste período pertenciam ao grupo A, corroborando os estudos anteriores. (Kaplan, et al., 2008).

Dados da literatura descrevem surtos nos quais os dois grupos podem circular com a mesma frequiência, independente da época e local onde o surto ocorra. Em uma pesquisa sobre a circulação dos dois grupos realizada em Caen na França, durante oito epidemias consecutivas, de 1982 a 1990, foi demonstrado não haver predominância de um grupo sobre o outro (Freymuth, et al., 1991).

O estudo realizado por Takahashi (2001) sobre a patogenicidade ocasionada pelo VSRH demonstrou não haver diferença significativa entre os grupos A e B. Resultados semelhantes foram encontrados por outros autores (Russi, et al., 1989; Brouard, et al., 1993 ) entretanto alguns outros identificaram maior gravidade relacionada com o grupo A do vírus (Taylor, et al., 1989; Hall, et al., 1990). Há ainda autores que verificaram relação do grupo B com doenças mais graves (Zelaya, et al., 1994; Hornsleth, et al., 1998). Os dados da literatura são divergentes, não ficando clara a existência ou não de patogenicidade entre os grupos. São necessários, pois, estudos adicionais, que possam determinar padrões em relação à diferença do grau de severidade e proporcionem, assim melhor entendimento das infecções causadas por este vírus.

Muitos são os métodos utilizados para estudar a variabilidade genética do VSRH, dentre eles: o ensaio de proteção à ação da ribonuclease (Cristina, et al., 1990), reação em cadeia pela polimerase após transcrição reversa (RT-PCR), (Zheng, et al., 1996). Análise por Enzima de Restrição (RFLP), (Johnson 1987; Sullender, et al., 
1991). Sequenciamento dos genes F, N, SH, P e G e Reação em Cadeia pela Polimerase (PCR). (Cane, et al., 1991; Sullender, et al., 1991; Peret, et al., 1998)

Cane e Pringer (1991) utilizaram a sequência parcial de nucleotídeos e o mapeamento de restrição para analisar os produtos da PCR dos genes $\mathrm{SH}$ e N respectivamente. A análise de 12 amostras isoladas entre o ano de 1956 e 1998 confirmou a heterogeneidade dos dois grupos A e B, sendo verificados apenas $76 \%$ de similaridade entre as sequiências de aminoácidos da proteína SH. A análise de 26 amostras do grupo A, por este método revelou variabilidade genética intragrupo. Foram identificadas desta forma, diferentes linhagens, denominadas genótipos, dentro de cada grupo: SHL de 1 a 6 para o grupo A e NP1 e NP3 para o grupo B. A análise filogenética das sequiências do gene $\mathrm{G}$, das amostras representantes dos genótipos acima, gerou uma árvore com clusters semelhantes aos obtidos na análise do gene $\mathrm{SH}$, confirmando a genotipagem inicial (Cane, et al., 1991).

Posteriormente, a análise da variabilidade, em cinco surtos consecutivos no Reino Unido, mostrou tanto a co-circulação de vários genótipos em um mesmo surto, quanto a predominância de um genótipo em um determinado surto. Observou-se, ainda o aumento da circulação do grupo A no decorrer dos anos declinando em anos seguintes, possivelmente indicando uma resistência da comunidade a um genótipo particular (Cane, et al., 1994).

O estudo realizado por Botosso (2002) sobre a diversidade genética das amostras de VSRH identificadas na cidade de São Paulo, pela análise das sequências parciais do gene $\mathrm{G}$, verificou a circulação de múltiplas linhagens, 1 ou 2 genotipos predominando a cada ano, o aumento de circulação de alguns genótipos e o declínio de outros no decorrer dos anos, corroborando dados da literatura (Seki et, al., 2001; Venter, et al., 2001).

O estudo da análise filogenética das sequiências do gene SH de amostras isoladas durante o surto de 1999 em New Hawen, Connecticut (EUA), comparados com seqüências de vírus isoladas em outras regiões dos Estados Unidos, América do Sul e Europa com seqüências de cepas isoladas em 1961, revelou que este gene é relativamente conservado. Verificaram-se poucas substituições não sinônimas, sugerindo que estudo mais aprofundado sobre esta glicoproteína pode ser primordial no desenvolvimento de uma terapia antiviral (Chen, et al., 2000). 


\subsection{Diagnóstico laboratorial}

Os quatro principais métodos de diagnóstico do VSRH são isolamento de vírus em cultura celulares, detecção de antígenos por imunofluorescência (IF) e/ou ensaio enzimático (ELISA), detecção do RNA viral pela técnica de RT-PCR (reação em cadeia pela polimerase após transcrição reversa) e Sorologia pela presença de $\operatorname{Ig} M$ especifico para VSRH e/ou por soro conversão. (Falsey e Walsh. 2000; Cane, 2001).

O método de isolamento viral em cultura celular para VSRH é uma técnica de diagnóstico presuntiva que permite a multiplicação de uma pequena quantidade de vírus presente na amostra, observada pelo aparecimento de efeito citopático ou seja, a formação de células gigantes e sincícios resultantes da fusão de células que pode aparecer em um período de 1 a 15 dias. A confirmação do diagnóstico vírus é realizado por métodos de detecção de antígenos ou por técnicas moleculares. (Halstead, et al., 1990; Van Endel, et al., 2003)

$\mathrm{O}$ isolamento do vírus em cultura celular é considerado o padrão ouro para o diagnóstico do VSRH. O mesmo pode crescer em uma variedade de linhagens celulares, principalmente em células epiteliais humanas tais como a HEp2 (carcinoma epitelial de faringe humano) e HeLa (carcinoma epitelial de cervix humano). Outras linhagens como Vero (células de rim de macaco) e fibroblastos humanos também são úteis para o isolamento do VSRH, mas não são tão sensíveis quanto às linhagens epiteliais humanas (Tristam e Welliver, 1996; Falsey e Wash, 2000).

Hierholzer e colaboradores demonstraram, em 1993, que a linhagem NCI-H292 (carcinoma mucoepidemoide de pulmão humano) também é bastante sensível para o isolamento do VRSH. Em estudo realizado por Perini et al. (2007) foi observado que a célula HeLa-I é adequada para isolamento viral, mostrando resultados semelhantes aos alcançados com a utilização de células HEp-2. A combinação de várias linhagens de células como HEp-2, HeLa, NCI-H292 mostrou-se mais eficiente do que o uso de somente um tipo. Com a utilização das três linhagens celulares verifica-se uma sensibilidade de até 95\%, enquanto com duas linhagens é de 90\%. (Arens, et al., 1986).

Apesar de o isolamento do vírus em cultura celular ser um excelente método de detecção, vários fatores podem interferir na sua eficácia, entre eles estão as condições da coleta e o manuseio das amostras, a presença de bactérias ou mesmo de outros vírus, diminuindo ou até mesmo anulando o efeito citopático produzido pelo vírus (Kellogg, 1991). 
O VSRH é um vírus termolábil, necessitando portanto de condições adequadas para o transporte e devendo ser processado em até no máximo 4 horas após a coleta. Outro fator importante é a refrigeração, sob a qual deve ser mantido a $4{ }^{\circ} \mathrm{C}$ até ser processado, uma vez que os títulos nas amostras virais podem cair rapidamente em temperatura ambiente. Após o processamento a amostra deverá ser imediatamente estocada a $-70{ }^{\circ} \mathrm{C}$ (Kellogg, 1991; Englund, et al., 1996; Falsey e Wash, 2000). Atualmente a cultura viral que apresenta efeito citopático característico para VSRH, é confirmada por imunofluorescência utilizando anticorpos monoclonais comerciais (van Elder, et al., 2002).

A utilização das técnicas rápidas para a detecção do VSRH é extremamente importante, principalmente em pacientes imunocomprometidos, em relação aos quais um diagnóstico rápido é critério importante para a terapêutica precoce, como em transplantados de medula óssea e prematuros que necessitam de intervenções rápidas (Englund, et al., 1996).

A técnica de imunofluorescência (IF) é largamente utilizada para detectar o VSRH em células epiteliais da nasofaringe ou para confirmação do isolamento do vírus após a cultura de células. Este teste é um método rápido e de fácil execução, apresenta alta sensibilidade e especificidade quando comparado ao isolamento viral, o que resulta em menos tempo de trabalho (Kellogg, 1991). Entretanto esse método apresenta algumas desvantagens tais como: a necessidade de pessoal bem treinado para a leitura, já que o mesmo pode apresentar inespecificidade devido a presença de muco na amostra. Durante o preparo da lâmina, o muco pode ser removido ou diminuído com adição de agentes mucolíticos como $\mathrm{N}$-acetilcisteína, ou ainda quebrado por pipetagens sucessivas (Kellogg, 1991).

Os padrões de fluorescência observados dependem dos monoclonais utilizados: monoclonais contra as glicoproteínas de superfície (G e F) apresentam um padrão de fluorescência de membrana, enquanto os monoclonais contra proteínas de nucleocapsídeo (N e P) apresentam padrão citoplasmático de fluorescência. Embora a IF seja considerada o método de escolha para diagnóstico rápido, este método depende da qualidade da amostra, a qual deve conter um bom número de células. Por isso a coleta deve ser realizada somente por profissionais bem treinados, além de transporte e processamento adequados, para que as células não sejam destruídas. (Tristam eWelliver, 1996). 
Outro método que pode ser utilizado para a detecção rápida do VSRH é o imunoenzimático. Este teste, geralmente, utiliza anticorpos monoclonais (MABs) ,marcados com peroxidase, para a captura do antígeno (Sarkkinem, et al., 1981). Os ensaios imunoenzimáticos possuem algumas vantagens quando comparados à fluorescência, já que não necessitam de células intactas do trato respiratório, e pelo seu potencial de automação, que permitiria o processamento de um grande número de amostras simultaneamente. Além disso, o método é mais objetivo na interpretação dos resultados do que a fluorescência (Kellogg, 1991). A desvantagem da técnica imunoenzimática é que esta parece não ser tão sensível quanto a imunofluorescência. (Abels, et al., 2001; Falsey, et al., 2000; Kellogg, 1991).

A técnica de RT-PCR, que detecta o ácido nucléico do vírus diretamente da amostra, tem sido amplamente utilizada para o diagnóstico do VSRH. É considerada uma técnica de alta sensibilidade, principalmente quando a quantidade e a excreção do vírus são pequenas (Peret, et al., 1998, 2000; Ong, et al., 2001).

Atualmente outros métodos de diagnóstico por biologia molecular tem sido desenvolvidos com alta sensibilidade, especificidade e rapidez do diagnóstico de infecções virais. Vários multiplex-PCR e RT-PCR foram desenvolvidos, demonstrando sensibilidade igual ou superior à cultura de células e a outros métodos de detecção de antígenos (Weinberg, et al., 2004; Rovida, et al., 2005).

Uma variação da técnica de RT-PCR utilizada recentemente na detecção de viroses respiratórias é o ensaio de RT-PCR detectado por GeneScan-RT-PCR (GS-RTPCR). Este método analisa os fragmentos de DNA com base na detecção automática de fluorescência durante eletroforese em capilar, bastante utilizada em procedimentos que requerem precisão no tamanho e na quantidade do produto de DNA, incluindo seleção e validação de SNP (single nucleic polimorfism), análise de microsatélites, detecção de polimorfismo e outros (Thomazelli, et al., 2004).

O GeneScan em aplicações de PCR baseia-se na utilização de um primer marcado com fluorescência e outro não marcado utilizado para amplificar um alvo específico que gerará produtos de tamanho esperado. O produto amplificado é combinado com um peso molecular padrão e submetido a uma eletroforese em seqüenciador automático, no qual o produto fluorescente é medido e quantificado. (Thomazelli, et al., 2004).

Em 2004 Thomazelli comparou a imunofluorescência com a técnica de GeneScan-TR-PCR para diagnósticos de diversos vírus respiratórios, e constatou que 
esta técnica possui boa sensibilidade e especificidade quando comparadas à outra simultaneamente.

O estudo realizado em 2008 por Nascimento et al., padronizou a RT-PCR em tubo único para diagnóstico de VSRH em amostras clínicas, a fim de simplificar e reduzir os riscos de contaminação. As amostras foram testadas por imunofluorescência indireta e por RT-semi-Nested PCR em tubo único. Os resultados obtidos demonstraram ser esta uma técnica rápida, sensível e específica, além de ser economicamente mais viável.

Outra técnica também já disponível é o Real-Time PCR, que detecta, quantifica e tipa o VSRH simultaneamente através da captação de sinais de fluorescência durante os ciclos da PCR. Atualmente esta técnica tem sido amplamente utilizada por apresentar alta sensibilidade e especificidade para detecção do VSRH em amostras clínicas (Hu, et al., 2003).

\subsection{Profilaxia e Tratamento}

As formas de tratamento mais utilizadas para as infecções virais do trato respiratório inferior causadas pelo VSRH são a oxigenoterapia, a remoção mecânica das secreções, posicionando a criança de forma adequada e o uso de broncodilatadores, (Wahab, et al., 2001; Collins, et al., 2001).

As internações somente são necessárias para os casos mais graves, em geral devido à insuficiência respiratória, à broncopneumonia, podendo levar alguns dias de hospitalização, e em alguns casos os pacientes podem necessitar de terapia intensiva e ventilação mecânica (Wahab, et al., 2001).

Atualmente a Ribavirina inalatória é o único medicamento antiviral licenciado para o tratamento de infecções causadas pelo VSRH. A ribavirina (1- $\beta$-D-ribofuranosyl1,2,4-triazole-3-carboxamide) é um nucleosídeo sintético, análogo à guanosina, com atividade neutralizante contra diversos vírus entre os quais o VSRH. A droga é prontamente transportada para dentro das células, onde, é então convertida por enzimas celulares a 5-mono-,di- e derivados de trifosfato, os quais são responsáveis por inibir certas enzimas virais como inosina-monofosfato desidrogenase que é envolvida na síntese de guanosina-monofosfato envolvida na síntese do ácido nucléico viral. A ribavirina produz seu efeito antiviral, principalmente, por alterar os agrupamentos de 
nucleotídeos e a formação de RNA mensageiro normal, o qual pode ser responsável por sua eficácia contra os vírus de RNA e DNA.. A composição dos agrupamentos de nucleotídeos é notadamente alterada após adição de ribavirina às culturas celulares (Chidgey e Broadley 2005).

Vários estudos com a ribavirina concluíram que apesar de a mesma ser capaz de inibir a replicação do VSRH e aumentar a saturação de oxigênio em crianças com infecção do trato respiratório inferior e infecção pulmonar crônica, não há evidências de que haja diminuição das taxas de mortalidade, duração de hospitalização ou terapia de suporte. Estes resultados contraditórios aliados ao alto custo, um tratamento que requer altas doses para ser eficaz, à administração aerossolizada prolongada de 12 a 18 horas diárias e mais sete dias de aplicação, à eficácia clínica limitada no tratamento de infecções por VSRH, tudo isto faz com que o uso da ribavirina tenha sua validade contestada (Collins, 2001; Broughton, et al., 2003; Ventre, et al., 2004; Xu, et al., 2004).

A terapia com glicocorticosteróides e broncodilatadores ainda não está bem definida. Entretanto Vuvojic e colaboradores sugeriram, em 2001, que com o uso de glicocorticóides seria possível controlar a resposta inflamatória nos pulmões após infecção pelo VSRH

Atualmente, existem dois tipos de imunoglobulinas que estão disponíveis para o tratamento profilático do VSRH. A imunoglobulina RSV-específica, (RSV-IGIV; RespiGam, MedImmune Inc) e o Palivisumab, são ambos imunoglobulinas capazes de reduzir o número de internações, tempo de hospitalização e a necessidade de admissão em UTI (Maggon e Barik 2004; Girard, et al., 2005).

A RSV-IGIV (Respigam) é uma preparação policlonal contendo anticorpos neutralizantes concentrados produzidos do soro de adultos humanos (Chidgey e Broadley 2005).

O palivizumab é um anticorpo monoclonal ( $\mathrm{IgG}$ ) de camundongo humanizado direcionado para um determinante antigênico no sítio antigênico A da proteína de fusão do VSRH. Este é um anticorpo monoclonal humanizado possui $95 \%$ de seqüência de aminoácidos humanos e $5 \%$ de murinos. É composto de duas cadeias pesadas e duas cadeias leves e apresenta um peso molecular de aproximadamente 148.000 Daltons. Seu mecanismo de ação consiste em neutralizar e inibir a fusão do VSRH, inibindo a replicação viral. O palivizumab reduz em média 99\% da replicação pulmonar (Chidgey e Broadley 2005) e é o único anticorpo monoclonal aprovado pela Food and Drugs Administation (FDA) em 1997, nos Estados unidos em 1998, na Europa em 1999, no 
Japão em 2002 e atualmente está disponível em 62 países. Está indicado na prevenção de doenças graves do trato respiratório inferior causadas por VSRH, principalmente, em pacientes pediátricos de alto risco, como bebês com displasia pulmonar (DBP), bebês prematuros com idade gestacional igual ou inferior a 35 semanas e em crianças com doença cardíaca congênita (DeVincenzo, 2008)

Estudos demonstram que o uso de palivizumab como profilático reduz entre $45 \%$ a $56 \%$ de hospitalizações. Foram observadas reduções tanto em crianças com displasia pulmonar (redução de 38\%), como em crianças prematuras sem DBP (redução de 78\%) (DeVincenzo, 2008). O palivizumab foi recentemente incluído nas normas de recomendação de uso da Sociedade Brasileira de Pediatria e oficializado para uso desde 2005 pela secretária de Saúde de São Paulo (http://www.saude.sp.gov.br/content/geral_acao_politica_estadual_medicamentos_vsr_ prevencao.mmp).

O mais recente medicamento que está sendo testado para o tratamento de VSRH é o Motavizumab, anteriormente conhecido como Numax (R), é um anticorpo monoclonal (AcM) humanizado que está sendo avaliado por seu potencial de prevenção de infecções pelo VSRH no trato respiratório inferior. Estudo comparativo com o palivizumab e o motavizumab mostrou que o perfil de segurança do motavizumab é similar ao palivizumab para bebês. Além disso o índice de hospitalizações foi reduzido em $26 \%$ e a incidência de infecções do trato respiratório inferior causadas por VSRH que exigiam tratamento médico ambulatorial reduziu-se em 50\%. (DeVincenzo, 2008) Outra forma de prevenção seria a vacina, porém o desenvolvimento de uma vacina segura e eficaz contra o VSRH é complicado pelo fato de a resposta imune contribuir para a patogenicidade da doença. Outro fator é a proteção conferida pelos anticorpos maternos nos primeiros meses de vida (Collins e Brian 2005; Girard, et al., 2005). Dois tipos de vacinas estão sendo desenvolvidos atualmente para diferentes grupos de indivíduos. Tais como a combinação de vacinas de vírus atenuado, deve ser útil para idosos, mães grávidas e crianças de alto risco. A administração de vacinas baseadas na proteína $\mathrm{F}$ mostrou segurança em adultos saudáveis, em crianças maiores de um ano com ou sem doença respiratória em idosos e mulheres grávidas (Girard, et al., 2005).

A mais nova farmacoterapia de drogas antivirais tem sido desenvolvida à base de RNAs de interferência (siRNA), que são pequenos pequenos RNAs de dupla fita que medeiam a interferência. É inicialmente processado dando origem a um intermediário dupla fita. Esses pequenos RNAs de interferência são fitas complementares ao RNA 
viral alvo, contendo de 21 a 23 nucleotídeos que hibridizam na extremidade 3 de fita do RNA Viral que se encontram sob forma de fita simples (Barik, 2004; Devincenzo, et al., 2007). A principal vantagem de se usar os siRNA é que não necessita da elucidação da estrutura da proteína sendo teoricamente possivel construir siRNA para qualquer RNA viral, bastando apenas saber qual é a sequência do virus. Um grande numero de RNAm é indispensável para o ciclo de vida viral, fazendo com que eles sejam alvos para ação do silenciamento gênico, o que diminui assim a chance de escapes mutantes e também de vírus com resistência à droga. (Barik, 2004).

Estudos recentes desenvolvidos por Devincenzo, et al., 2007 indicaram o uso de ALN-RSVO1 que é um siRNA direcionado contra o RNAm codificador da proteína $\mathrm{N}$ do vírus sincicial respiratório como alvo especifico in vitro e in vivo com atividade anti$\mathrm{RSV}$, como um candidato forte na terapêutica do vírus sincicial respiratório humano. 


\section{OBJETIVOS}

2.1 Analisar a variabilidade genética do gene da proteína SH (Small Hydrophobic Protein) do VSRH em isolados de crianças atendidas e internadas no Hospital Universitário da Universidade de São Paulo- HUSP, durante dois anos consecutivos.

2.2 Comparar os resultados da análise do sequenciamento da proteína $\mathrm{SH}$ com o sequenciamento da proteína $\mathrm{G}$. 


\section{MATERIAIS E MÉTODOS}

\subsection{Casuística}

No período de janeiro de 2004 a dezembro de 2005 foram colhidas amostras de 965 crianças, menores de 5 anos de idade com doenças respiratórias agudas e atendidas nos diferentes setores do Hospital Universitário da Universidade de São Paulo (HUUSP), enfermaria da pediatria, retaguarda da pediatria, berçário e unidade de terapia intensiva neonatal e pediátrica. Os espécimes foram colhidos com o consentimento dos pais ou responsáveis, que assinavam um termo de consentimento aprovado pela Comissão de Ética de pesquisa do Hospital Universitário e Instituto de Ciências Biomédicas da Universidade de São Paulo (USP). Todas as amostras foram submetidas a um procedimento padrão do Laboratório de Virologia Clínica e Molecular do ICB/USP (LVCM-ICB/USP) para diagnóstico e epidemiologia molecular, como mostra o fluxograma da figura 5. 


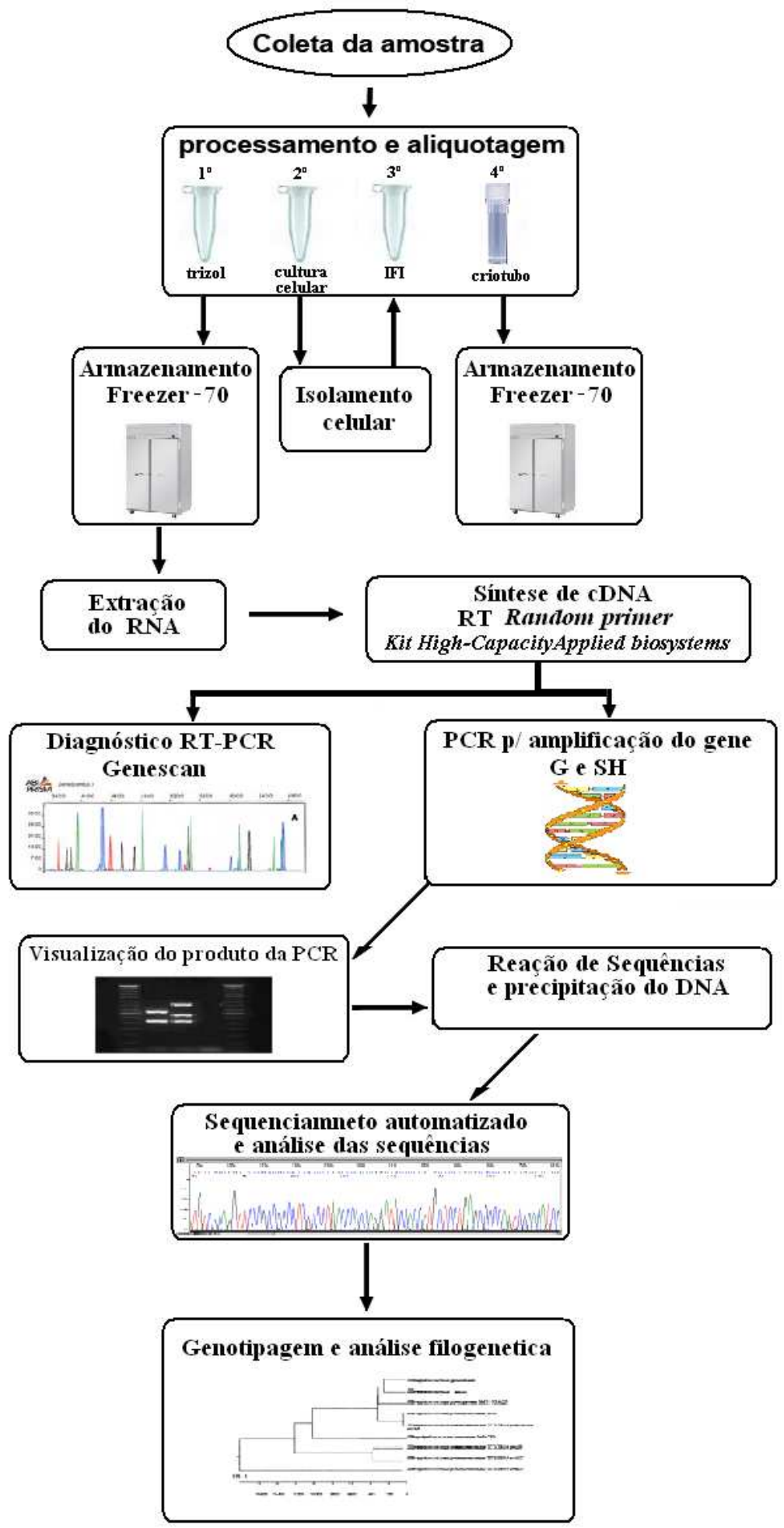

Figura 5 - Fluxograma de trabalho desenvolvido no Laboratório de Virologia Clínica Molecular (LVCM-ICB II / USP), a partir do material clínico colhido no Hospital Universitário (HU). 


\subsection{Diagnóstico do VSRH}

\subsubsection{Colheita das Amostras}

O material colhido consistiu de aspirado de secreção da nasofaringe e swab nasal. De uma das narinas foi colhido espécime clínico, com um swab e transferido imediatamente, para um frasco contendo PBS estéril. Na outra narina foi introduzido um cateter esterilizado que, à vácuo, aspirava a secreção nasofaringe depositando-a em equipo de solução parenteral. Os materiais foram transportados, em gelo, para o laboratório de Virologia Clinica e Molecular do Instituto de Ciências Biomédicas da (LVCM-ICB-II/USP) e processados em período máximo de 4 horas.

\subsubsection{Processamento das Amostras}

O aspirado e o meio contendo o swab foram misturados, homogeneizados e tratados com $1000 \mathrm{U} / \mathrm{mL}$ de penicilina e $1000 \mu \mathrm{g} / \mathrm{mL}$ de estreptomicina (Gibco BRL ${ }^{\circledR}$ ). Após 30 minutos a $4{ }^{\circ} \mathrm{C}$, as amostras (cerca de $3 \mathrm{~mL}$ ) foram separadas em $900 \mu \mathrm{L}$ para inoculação em cultura de células; $1500 \mu \mathrm{L}$ para imunofluorescência indireta, IFI; 250 $\mu \mathrm{L}$ de amostra para RT-PCR, após acrescentar $750 \mu \mathrm{L}$ de Trizol LS (Gibco BRL ${ }^{\circledR}$ ), e o restante, cerca de $400 \mu \mathrm{L}$, foi armazenado a $-70{ }^{\circ} \mathrm{C}$, após adição de meio de congelamento, volume a volume (meio mínimo essencial Eagle - MEM), modificado com sais de Earle, com glutamina (Sigma Chemical Co., St. Louis, MO), acrescido de $10 \%$ de soro fetal bovino (SFB - Cultilab) e 10\% de glicerina esterilizada (Sigma Chemical Co., St Louis, MO).

\subsubsection{Extração do RNA Total}

$\mathrm{Na}$ extração do ácido nucleico das amostras clínicas foi utilizada a alíquota estocada com Trizol LS. Todo o processo de extração foi realizado em banho de gelo, com reagentes gelados e centrífuga refrigerada (Centrifugue 5804R Eppendorf). A $1 \mathrm{~mL}$ de aliquota $(250 \mu \mathrm{L}$ de aspirado com $750 \mu \mathrm{L}$ de Trizol LS) foram adicionados $200 \mu \mathrm{L}$ de clorofórmio: álcool isoamílico 24:1 (Merck-Sigma). Após a homogeneização em 
vórtex por 15 segundos e incubação por 5 minutos em banho de gelo, a amostra foi centrifugada a $3000 \mathrm{~g}$ por 15 minutos a $4{ }^{\circ} \mathrm{C}$. A fase aquosa, cerca de $400 \mu \mathrm{L}$, foi transferida para outro tubo, sendo o RNA precipitado pela adição de isopropanol (Sigma Chemical Co., St. Louis, MO) volume a volume, seguido de homogeneização em vórtex, incubação em banho de gelo por 15 minutos e centrifugação a 3000 g por 15 minutos a $4{ }^{\circ} \mathrm{C}$. A seguir, o sobrenadante foi descartado e o precipitado lavado com 800 $\mu \mathrm{L}$ de etanol a 75\% (Merck) diluído em água Milli- $\mathrm{Q}^{\circledR}$ tratada com DEPEC (Dietilpirocarbonato - Sigma Chemical Co., St. Louis, MO), seguido de centrifugação a $3000 \mathrm{~g}$ por 8 minutos a $4{ }^{\circ} \mathrm{C}$. O sobrenadante foi descartado e o precipitado foi novamente suspenso em $20 \mu \mathrm{L}$ de água tratada com DEPEC contendo $40 \mathrm{U}$ de Inibidor de Ribonuclease (Rnasin ${ }^{\circledR}$ - Promega Product, Information).

\subsubsection{Obtenção do DNA complementar (cDNA)}

A transcrição reversa foi realizada utilizando High Capacity cDNA Archive kit (Applied Biosystems $^{\circledR}$ ), onde $50 \mu \mathrm{L}$ de RNA extraído foram diluídos em mix contendo $10 \mu \mathrm{L}$ de Random primers 10X, $10 \mu \mathrm{L}$ tampão da RT 10X, $250 \mathrm{U}$ de MultiScribe RT enzyme, $4 \mu \mathrm{L}$ de dNTP mix [100mM], $1 \mathrm{U}$ de inibidor de Ribonuclease (Rnasin ${ }^{\circledR}$ Promega Product, Information) e água DEPEC para completar o volume de $100 \mu \mathrm{L}$. A mistura foi incubada a $25{ }^{\circ} \mathrm{C}$ por 10 minutos seguido de $37{ }^{\circ} \mathrm{C}$ por 120 minutos no termociclador (Mastercycler Personal Eppendorf).

\subsubsection{Diagnóstico de VSRH por GeneScan RT-PCR}

\subsubsection{Primers}

Primers complementares a região correspondente a subunidade F1 do gene da glicoproteína de fusão (Mazzulli, et al., 1999; Erdman, et al., 2003) foram utilizados para amplificação parcial do gene F. O primer sense possuía um marcador fluorescente (FAM - Gibco BRL). A seqüência dos primers, com a localização no genoma esta descrita na Tabela 1. 
Tabela 1 - Primers utilizados na amplificação da proteína F do VSRH, para a PCRGeneScan.

\begin{tabular}{cccc}
\hline Primer & Posição (gene) & Seqüiência & Referência \\
\hline RSVAB F1 & Proteína F+ & AACAGTTTAACATTACCAAGTGA & Erdman, et al., \\
FAM (+) & $(1111-1134)$ & & 2003 \\
RSVAB & Proteína F- & TCATTGACTTGAGATATTGATCG & Erdman, et al., \\
R1 (-) & $(1468-1490)$ & & 2003 \\
\hline
\end{tabular}

\subsubsection{PCR GeneScan}

As amostras colhidas neste período foram submetidas ao diagnóstico diferencial para oito vírus (VSRH, Influenza A e B, Parainfluenza 1, 2 e 3, Adenovirus e Metapneumovirus), utilizando o método de GeneScan RT-PCR proposto por (Erdman, et al., 2003) e adaptado ao diagnóstico da rotina por (Thomazelli, et al., 2007).

A PCR por GeneScan do (LVCM-ICB/USP) foi realizada a partir $10 \mu \mathrm{L}$ do cDNA diluído em tampão Tris- HCL 20 mM [pH 8.4] / 50 mM de KCL / 1.5 mM de $\mathrm{MgCl}_{2}$ (Applied Biosystems $\left.{ }^{\circledR}\right), 4 \mu \mathrm{L}$ de dNTP, [1.25mM] e água Milli-Q q.s.p $50 \mu \mathrm{L}$. As amostras foram amplificadas em termociclador GeneAmp PCR System 9700 (Applied Biosystems ${ }^{\circledR}$ ), inicialmente à $94{ }^{\circ} \mathrm{C}$ por 5 minutos seguido de 35 ciclos de 94 ${ }^{\circ} \mathrm{C} / 1$ minuto , $54{ }^{\circ} \mathrm{C} / 1$ minuto, e $72{ }^{\circ} \mathrm{C} / 1$ minuto e uma etapa final de $72{ }^{\circ} \mathrm{C}$ por 5 minutos. Os produtos foram estocados a $4{ }^{\circ} \mathrm{C}$, até a detecção do produto amplificado.

\subsubsection{Detecção dos produtos amplificados}

Os produtos foram analisados e quantificados utilizando o Analisador Automático de DNA ABI_Prism modelo 310 (Applied Biosystems ${ }^{\circledR}$ ), com detecção para marcadores fluorescentes, utilizando o programa GeneSaca; para a análise de fragmentos de DNA no ABI Do produto da PCR, $1 \mu \mathrm{L}$ foi misturado com $11 \mu \mathrm{L}$ de formamida deionizada e $0,75 \mu \mathrm{L}$ de sizestandard (GeneScan TAMRA ${ }^{\mathrm{TM}}$ 500). A inclusão do padrão de peso molecular em cada amostra permitiu a compensação de 
eventuais variações que pudessem ocorrer entre as corridas eletroforéticas. Essa mistura foi colocada no termociclador para denaturação: $95{ }^{\circ} \mathrm{C}$ por 3 minutos e imediatamente colocada em gelo até a análise no aparelho ABI 310. Os produtos foram submetidos a corrida eletroforética no interior de um capilar medindo $47 \mathrm{~cm}$ de comprimento, preenchido por um polímero POP-4 (Applied Biosystems ABI ${ }^{\circledR}$ ). A injeção da amostra no capilar durou 5 segundos e a eletroforese foi realizada durante 40 minutos a 15.000 volts e $60^{\circ} \mathrm{C}$.

Os fragmentos marcados foram detectados por um feixe de laser e por uma câmara CCD utilizando-se um filtro virtual "A", e em seguida foram analisados pelo programa ABI 310 GeneScan (Applied Biosystems ${ }^{\circledR}$ ), produzindo eletroferogramas com dados quanto ao tamanho dos fragmentos em pares de bases (pb) e quanto à intensidade de fluorescência em unidades relativas de fluorescência (URF).

\subsection{Genotipagem do VSRH}

Todas as amostras positivas para VSRH por GeneScan RT-PCR durante os anos de 2004 e 2005, foram submetidas a genotipagem por sequenciamento parcial do Gene G como parte da rotina de diagnóstico do VSRH, do (LVCM/ICB-USP), seguindo a metodologia proposta por (Peret, et al., 1998) e adaptada à rotina do laboratório por (Botosso, et al., 2002, 2009) e sequenciamento completo do gene SH, utilizando os primers proposto por (Chen, et al., 2000)

\subsubsection{Seleção das amostras para o estudo de variabilidade do gene das proteínas G e SH}

Foram selecionadas todas as amostras positivas para VSRH pelo método GeneScan RT-PCR. A genotipagem foi realizada por sequenciamento parcial do Gene G, totalizando 80 amostras genotipadas em 2004 e 84 em 2005. Desse total de amostras, 121 foram submetidas à amplificação do gene da proteína $\mathrm{SH}$, utilizando primers proposto por (Chen, et al., 2000). 


\subsubsection{Seleção dos Primers para o Gene G}

Tabela 2 - Primers utilizados na PCR, Semi nested PCR e sequenciamento do gene G do VSRH.

\begin{tabular}{|c|c|c|c|c|}
\hline Primer & Utilizaçãa & $\begin{array}{c}\text { Posição } \\
\text { (nucleotídeos - nt) }\end{array}$ & Seqüência (5minutos - 3minutos) & Referência \\
\hline FV (-) & PCR & 163-186 gene $\mathrm{F}$ & GTTATGACACTGGTATACCAACC & $\begin{array}{l}\text { Zheng, et } \\
\text { al., } 1996\end{array}$ \\
\hline $\begin{array}{l}\text { FIAB } \\
(-)\end{array}$ & $\begin{array}{c}\text { Semi nested } \\
\text { sequenciamento }\end{array}$ & 3-22 gene $\mathrm{F}$ & CAACTCCATTGTTATTTGCC & $\begin{array}{l}\text { Peret, et } \\
\text { al., } 1998\end{array}$ \\
\hline Gr5 (-) & $\begin{array}{l}\text { PCR/Semi nested } \\
\text { sequenciamento }\end{array}$ & 151-173 gene $\mathrm{G}$ & CTGGCAATGATAATCTCAACTTC & $\begin{array}{c}\text { Sanz, et al., } \\
1994\end{array}$ \\
\hline $\begin{array}{c}\mathrm{GAB} \\
(+)\end{array}$ & $\begin{array}{l}\mathrm{PCR} / \text { semi nested } \\
\text { e sequenciamento }\end{array}$ & 504-524 proteína $\mathrm{G}$ & YCAYTTTGAAGTGTTCAACTT & $\begin{array}{l}\text { Peret, et } \\
\text { al., } 2000\end{array}$ \\
\hline
\end{tabular}

\subsubsection{Amplificação da seqüência do gene G}

As amostras positivas para VSRH pelo GeneScan foram submetidas a PCR para amplificação parcial do gene G. A PCR foi realizada partindo-se de $10 \mu \mathrm{L}$ do cDNA, diluídos no tampão 10X, 2,5 mM $\mathrm{MgCl}_{2}, 1.25 \mathrm{U}$ de taq DNA polimerase (Applied Biosystems $\left.{ }^{\circledR}\right), 50 \mathrm{pMol}$ de cada um dos primers, Gr5 e FV, $16 \mu \mathrm{L}$ dNTP [1,25mM] (Applied Biosystems ${ }^{\circledR}$ ) e água Milli-Q para completar o volume de $100 \mu \mathrm{L}$. As amostras foram amplificadas em termociclador MasterCycle gradiente (Eppendorf) a partir de uma etapa inicial de $96{ }^{\circ} \mathrm{C}$ por 2 minutos, seguida de 40 ciclos de $94{ }^{\circ} \mathrm{C} / 1$ minutos, 57 ${ }^{\circ} \mathrm{C} / 1$ minutos, $72{ }^{\circ} \mathrm{C} / 1$ minutos e uma etapa final de $72{ }^{\circ} \mathrm{C}$ por 7 minutos.

As amostras não amplificadas foram submetidas a uma segunda reação utilizando os primers F1AB e Gr5. 


\subsubsection{Seleção dos Primers para o Gene SH}

Foram utilizados primers previamente identificados por Chen, et al., 2000.

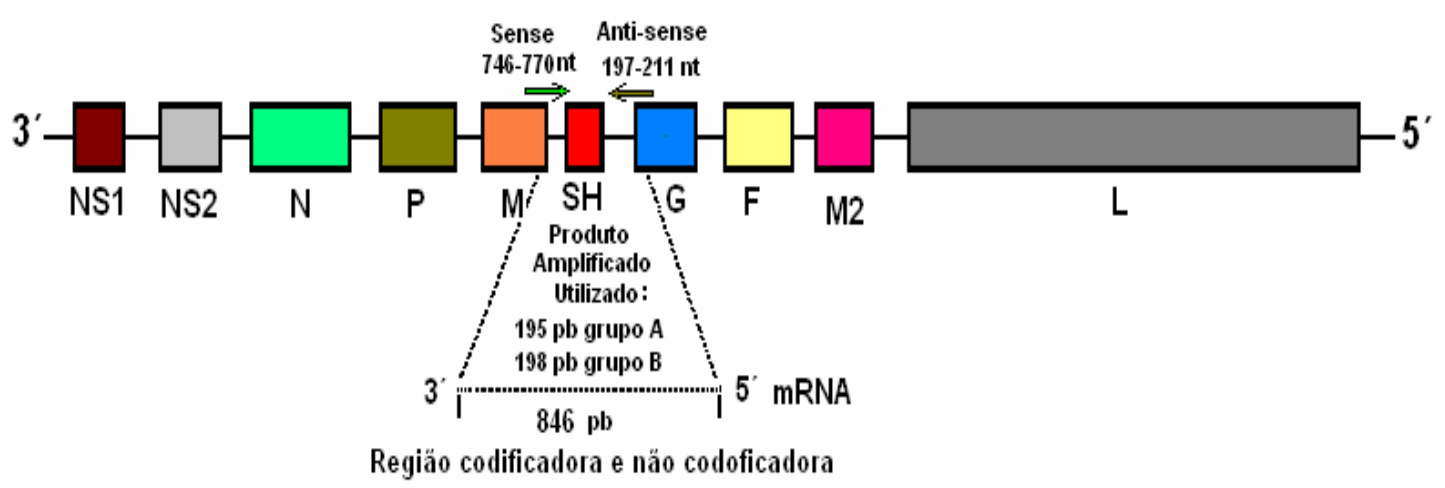

Figura 06- Esquema do genoma viral. Os genes estão identificados de acordo com a proteína que os codifica, os retângulos laranja e azul indicam a localização dos primers. O produto amplificado utilizado foi apenas a região codificadora indicada no esquema acima.

\subsubsection{Amplificação da seqüência do gene $\mathrm{SH}$}

A reação de PCR foi realizada utilizando o cDNA obtido conforme descrito nos itens 3.2.3 e 3.2.4 e estocado a $-70{ }^{\circ} \mathrm{C}$. A amplificação foi efetuada com a diluição de 10 $\mu \mathrm{L}$ cDNA em $10 \mu \mathrm{L}$ tampão $20 \mathrm{mM}$ de Tris-HCl [pH 8.4] 50mM de $\mathrm{KCl}, 2 \mathrm{mM}$ de $\mathrm{MgCl}_{2}$, 10 pMoles de cada primer Sense 5'CGCGCGCGCCCGGGCAGCTACACGTTTTTCA ATCAAACC-3’ Anti-Sense 5'-GCGCGCGgTtgagattatcattgCC-3’ 1 U de Taq Polimerase (Applied Biosystems $^{\circledR}$ ), $16 \mu \mathrm{L}$ de dNTP [1,25mM] e água milli-Q q.s.p. $100 \mu \mathrm{L}$. As amostras foram amplificadas em termociclador GeneAmp PCR System 9700 (Applied Biosystems $^{\circledR}$ ), O termociclador foi programado para uma etapa inicial de $95{ }^{\circ} \mathrm{C}$ por 10 minutos, 40 ciclos a $94{ }^{\circ} \mathrm{C}$ for 1 minuto para desnaturação, $55{ }^{\circ} \mathrm{C}$ por 1 minuto para o annealing, $72{ }^{\circ} \mathrm{C}$ por 1 minuto para extensão e uma etapa final, 7 minutos a $72{ }^{\circ} \mathrm{C}$ para extensão. 


\subsubsection{Detecção dos produtos amplificados dos genes G e SH}

A detecção do produto de PCR foi realizada por eletroforese em gel de agarose (Gibco BRL ${ }^{\circledR}$ ) a 1,5\% em tampão TBE 0,5X (45 mM de Tris-Borato e $1 \mathrm{mM}$ de EDTA [pH 8.0] e $0,5 \mu \mathrm{g} / \mathrm{mL}$ brometo de etídeo. Uma alíquota $10 \mu \mathrm{L}$ de amostra misturado com $2 \mu \mathrm{L}$ de azul de bromofenol (loadding buffer) foi submetida á eletroforese em cuba horizontal (Gibco BRL ${ }^{\circledR}$ ), imerso em tampão TBE durante 50 minutos a $100 \mathrm{~V}$. A visualização do gel foi realizada em trans-iluminador de luz ultravioleta (UV); sendo fotografado para uma análise mais detalhada.

\subsubsection{Purificação dos produtos amplificados dos genes G e SH}

O produto de PCR foi purificado para remoção de dNTPs e primers residuais por precipitação do etanol 100\% (Merck) e acetato de sódio a $3 \mathrm{mM}, \mathrm{pH}$ 5,29, seguido de lavagens com Isopropanol. a 100\%. Em $100 \mu \mathrm{L}$ do produto amplificado foram adicionados $10 \%$ do volume total de acetato de sódio a $3 \mathrm{mM}, \mathrm{pH} 5,29$ e $200 \mu \mathrm{L}$ de Etanol $100 \%$ (Merck) sendo então homogeneizado em vortex. Após um período de incubação de 3 horas a $-20^{\circ} \mathrm{C}$, as amostras foram centrifugadas por 30 minutos a $4.000 \mathrm{~g}$ a $4{ }^{\circ} \mathrm{C}$. O sobrenadante foi descartado e o precipitado lavado com $150 \mu \mathrm{L}$ de Isopropanol $75 \%$ e centrifugado por 10 minutos a 4.000 g. Novamente o sobrenadante foi descartado e após secagem em speed vacum a $60{ }^{\circ} \mathrm{C}$ por 20 minutos, o sedimento foi ressuspendido com $20 \mu \mathrm{L}$ de $\mathrm{H}_{2} \mathrm{O}$ Milli Q. Em seguida o produto foi submetido a eletroforese em gel de agarose a 1,5\%, e quantificado com auxilio de marcador de peso molecular (DNA Mass Ladder - BIOTOOLS). 


\subsection{Sequenciamento do Gene G}

A reação de sequenciamento foi realizada utilizando os primers FIAB e Gr5, com o kit ABI PRISM Dye ${ }^{\mathrm{TM}}$ Terminator Cycle Sequencing Ready Reaction kit (Big Dye v3.1 Appleid biossystems ${ }^{\circledR}$ ), seguindo instruções do fabricante.

Cerca de 10 - $30 \mathrm{ng}$ de produto da PCR purificados, foram adicionados a um microtubo acrescido de $2 \mu \mathrm{L}$ de tampão Save Money 5X (Tris HCL $200 \mathrm{mM}$ pH 9,0 e 5 $\mathrm{mM} \mathrm{MgCl}_{2}$ ), 3,2 $\mathrm{pMol}$ do primer, $2 \mu \mathrm{L}$ do kit ABI PRISM Dye ${ }^{\text {TM }}$ Terminator Cycle Sequencing Ready Reaction kit (Big Dye v3.1 Appleid biossystems ${ }^{\circledR}$ ) e água ultrapura completar um volume final de $10 \mu \mathrm{L}$. Este procedimento foi efetuado separadamente para cada um dos primers.

A reação foi realizada em termociclador MasterCycle gradient (Eppendorf ${ }^{\circledR}$ ) a partir de uma etapa de $96{ }^{\circ} \mathrm{C} / 1$ minutos seguidos de 25 ciclos de $96{ }^{\circ} \mathrm{C}$ por 15 segundos para a desnaturação do DNA, $50{ }^{\circ} \mathrm{C}$ por 15 segundos para o annealing dos primers e 60 ${ }^{\circ} \mathrm{C}$ por 4 minutos para a extensão.

\subsection{Sequenciamento do Gene SH}

Após a purificação as fitas de DNA foram seqüenciadas utilizando-se o kit " $A B I$ PRISM Dye TM Terminator Cycle Sequencing Ready Reaction kit" ("Big Dye” Applied Biosystems ${ }^{\circledR}$ Inc. EUA), seguindo as instruções do fabricante. Foram utilizados os mesmos primers da amplificação descritos anteriormente para o sequenciamento do gene $\mathrm{SH}$. Cerca de 1-3 $\mu \mathrm{L}$ (10 a $30 \mathrm{ng}$ ) do produto amplificado e purificado foram adicionados a um microtubo acrescido $2 \mu \mathrm{L}$ do tampão de sequenciamento Save Money 5X (Tris HCL 200mM [pH 9,0] e 5mM $\mathrm{MgCl}_{2}$ ), $3.2 \mathrm{pMol}$ do primer, $2 \mu \mathrm{L}$ do kit ABI PRISM Dye ${ }^{\mathrm{TM}}$ Terminator Cycle Sequencing Ready Reaction kit, (Big Dye v3.1 Applied Biosystems ${ }^{\circledR}$ ) e água Milli- $\mathrm{Q}^{\circledR}$ para completar um volume final de $10 \mu \mathrm{L}$. Este procedimento foi efetuado separadamente para cada um dos primers. A extensão enzimática foi realizada em termociclador GeneAmp PCR System 2400 durante 25 ciclos de $96{ }^{\circ} \mathrm{C}$ por 10 segundos para desnaturação do DNA, $50{ }^{\circ} \mathrm{C}$ por segundos para o annealing dos primers e $60{ }^{\circ} \mathrm{C}$ por 4 minutos para extensão. $\mathrm{O}$ produto obtido foi purificado, visando á remoção de excesso de dideoxinucleotideos "terminadores" 
presentes na reação, por precipitação com isopropanol a 75\%, seguido de lavagens com etanol a $75 \%$.

As amostras purificadas e precipitadas foram ressuspendidas com $10 \mu \mathrm{L}$ de formamida ultrapura (Formamida Hi-Di - Applied Biosystems ${ }^{\circledR}$ ) desnaturada a $95{ }^{\circ} \mathrm{C}$ por 3 minutos e resfriadas em banho de gelo por mais 2 minutos e então submetidas á eletroforese em polímero POP6 (Applied Biosystems ${ }^{\circledR}$ ), utilizando seqüenciador automático ABI-PRISM modelo 3100 (Applied Biosystems ${ }^{\circledR}$ ). As amostras foram traqueadas automaticamente utilizando software do analisador Automático de DNA ABI Prism modelo 3100.

\subsection{Alinhamento das Seqüências dos genes G e SH}

As seqüências de nucleotídeos foram analisadas com o programa Sequence Navigator versão 1.0 (Applied Biosystems ${ }^{\circledR}$ Inc. EUA) para Power Macintosh, de modo a obter um total de 263 nucleotídeos da região central conservada e a segunda região variável do gene codificador da glicoproteina G, G2 (Peret et al. 1998; Sulleder 2000). Para proteína SH foram analisados 195 pb grupo A, correspondendo ao nucleotídeo 85 a 281 e 198 pb do nucleotídeo 85 a 283 do grupo $\mathrm{B}$, correspondendo à região codificadora da proteína SH completa dos grupos A e B respectivamente (Chen et al., 2000). Posteriormente, estas seqüências foram traduzidas utilizando o programa Edit Seq $^{\mathrm{TM}} 4,05$ - Expert Analysis Software - DNASTAR, Inc para PC.

As seqüências de nucleotídeos foram alinhadas em dois grupos, A e B, com seqüências do grupo A e B publicadas no genbank usando para o grupo A, As seqüências AF512538, AY512538 (Lim, et al., 2003) AF280466 a AF280494 (Chen, et al., 2000) e para o grupo B RSB 641, RSN 7454, RSN 2, RSN 1599 (Cane, et al., 1991) e as protótipos A2, CH18537 e Sw8/60. Utilizando o programa Meg Align ${ }^{\mathrm{TM}} 4,05$ Expert Analysis Software - DNASTAR, Inc para PC. Ambos foram analisados concomitantemente, com o referido programa, tendo como resultado a obtenção do grau de similaridade entre as sequiências, calculadas par a par, o que possibilitou a identificação das seqüências de nucleotídeos idênticas.

Com intuito de otimizar as análises subseqüentes, tomou-se aleatoriamente, apenas uma amostra de cada grupo de sequiências idênticas. Desta forma apenas 
sequiências do grupo A e do grupo B, que apresentaram pelo menos uma mudança no número ou posição nucleotídeos, foram submetidas à análise filogenética.

\subsection{Análises Filogenéticas do gene G}

As seqüências de nucleotídeos do grupo A foram comparadas com as seqüências adquiridas do GenBank, incluindo os protótipos A2 e Long, e outras sequiências representando os principais genotipos (GA1 a GA7), descritos por (Peret, et al., 1998, 2000).

As seqüências de nucleotídeos do grupo B foram comparadas com outras sequiências adquiridas do GenBank, incluindo os protótipos Sw8/60, CH18537, e as sequiências GB1, GB2, GB3, GB4, SAB1, SAB2, SAB3 (Peret, et al., 1998).

\subsection{Análises Filogenéticas do Gene SH}

Para a análise da variabilidade de nucleotídeos intragenótipos, as seqüências representantes de cada genótipo foram alinhadas e analisadas, utilizando o programa Meg Align $^{T M} 4,05$, para obtenção do grau de similaridade entre as seqüências, calculadas par a par.

Os arquivos gerados pelo Meg Align $^{T M} 4,05$, foram convertidos para arquivos em formato NEXUS e utilizados para as análises genealógicas entre as cepas de VSRH dos grupos A e B, que foram realizadas empregando os critérios de Máxima Verossimilhança (MV), e o modelo evolutivo Hasegawa-Kishino-Yano mais distribuição Gama (model 15), obtidos após análise com o programa Modeltest site <http://hcv.lanl.gov/content/hcv-db/findmodel/matrix/all.html>. Foi realizada uma busca heurística, com algarismo de TBR (tree bisection reconnection). Utilizando uma árvore não enraizada, graças ao programa PAUP*4.0 versão Beta - Sinaur Associates, Inc. (Swofford, 1998), para Power Macintosh.

Foram calculados os valores de bootstrap com 100 réplicas, para a verificação da sustentação de ramos nas topologias das árvores obtidas (Felsenstein, et al., 1985). 


\section{RESULTADOS}

\subsection{Circulação e Sazonalidade das amostras dos anos de 2004 e 2005}

Durante os anos de 2004 e 2005, foram colhidas 965 amostras de crianças menores de 5 anos com sintomas respiratório atendidas no HU/USP, sendo que destas, 188 (42 \%) foram positivas no ano de 2004 e 236 (48,6\%) foram positivas em 2005. Essas amostras apresentaram uma sazonalidade bem definida nos dois anos estudados, com aumento da incidência entre os meses de março a junho, sendo que o pico do VSRH no ano de 2004 ocorreu em março e abril e no ano de 2005, foi nos meses de maio e junho, como mostra a Figura 7:

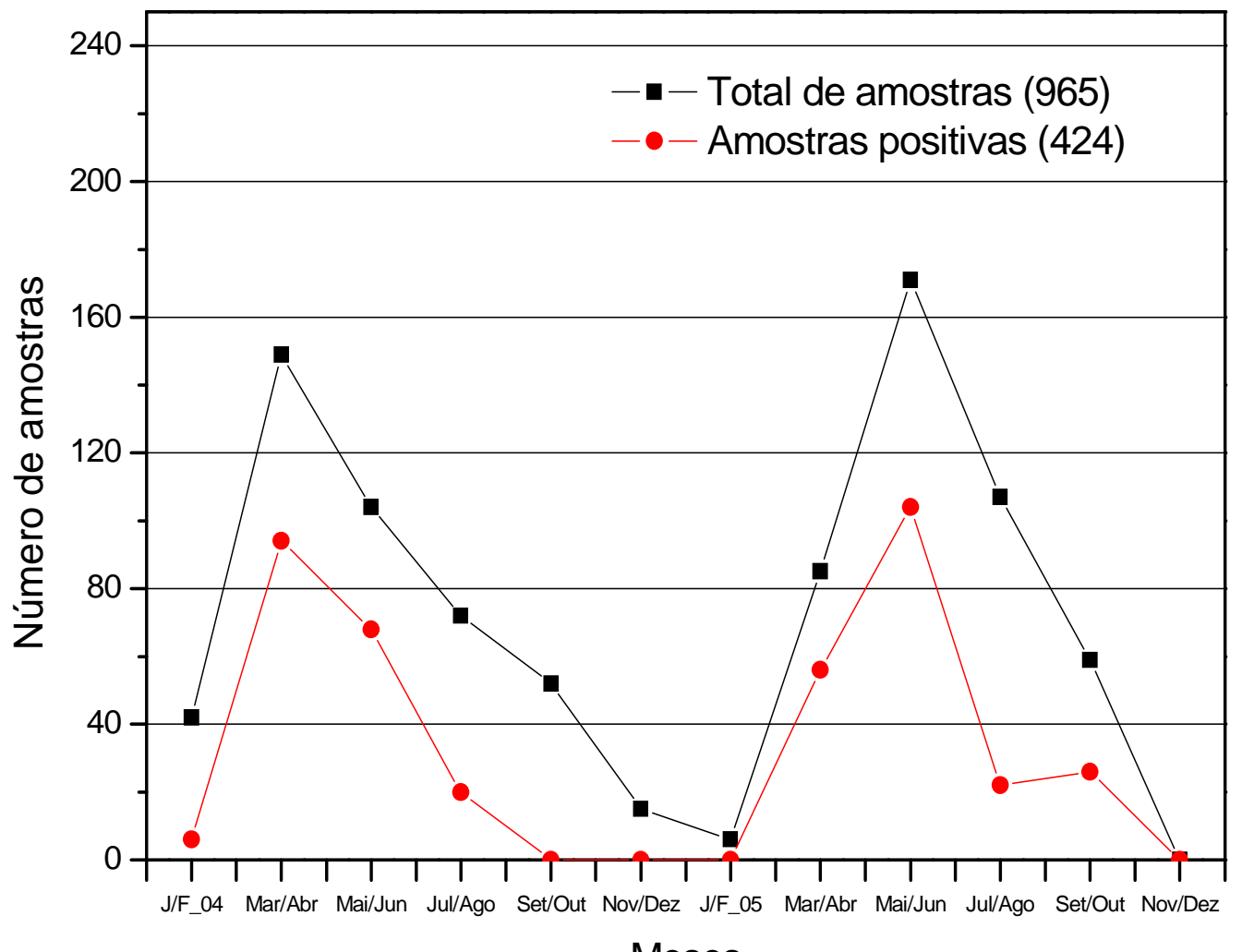

Meses

Figure 7 - Sazonalidade do VSRH em amostras colhidas durante o período de janeiro de 2004 a dezembro de 2005, no HU/USP com pico de incidência entre os meses de março e junho. 


\subsection{Epidemiologia molecular}

\subsubsection{Análise filogenética das amostras circulantes em 2004 e 2005 pela análise do gene $\mathbf{G}$}

Das 164 amostras genotipadas nos anos de 2004 e 2005 pelo gene G para VSRH, 117 foram amplificadas para o gene $\mathrm{SH}$ e seqüenciadas, para identificação e comparação dos genótipos. (Figuras 9 e 10, Anexos A e B).

Foi observada a circulação dos grupos A e B, com predominância do grupo A no ano de 2004 e do grupo B em 2005.

As seqüências do gene $\mathrm{G}$ obtidas foram alinhadas com seqüências representantes de vários genótipos previamente identificados (Peret, et al., 1998, 2000; Trento, et al., 2003; Venter, et al., 2001). A análise filogenética do gene $\mathrm{G}$ das seqüências brasileiras pertencentes ao grupo A revelou a existência de dois clusters correspondendo aos genótipos GA2 e GA5 (Figura 9, Tabela 3, Anexo A).

A análise do grupo $\mathrm{B}$ foram agrupadas em quatro clusters distintos correspondendo aos genótipos SAB1, SAB3, GB3 e BA-like. (Figura 10, Tabela 3, Anexo B).

Tabela 3 - Distribuição dos genótipos de VSRH circulantes nos anos de 2004 e 2005, obtidos pelo

Sequenciamento do gene G.

\begin{tabular}{c|cccccc}
\hline & \multicolumn{6}{|c}{ GENÓTIPOS } \\
\hline Ano & \multicolumn{7}{|c}{ Grupo A } & Grupo B & BA LIKE \\
& GA2 & GA5 & SAB1 & SAB3 & GB3 & B 04 \\
18 & 37 & 2 & 3 & 0 & 3 \\
2005 & 1 & 9 & 1 & 0 & 3 & 41 \\
\hline Total & 18 & 46 & 3 & 3 & 3 & 44 \\
\hline
\end{tabular}


Ao comparar as taxas de circulação dos genótipos encontrados em porcentagem, foi possível observar que os grupos A e B, circularam em igual proporção, porém em anos diferentes Figura 8.
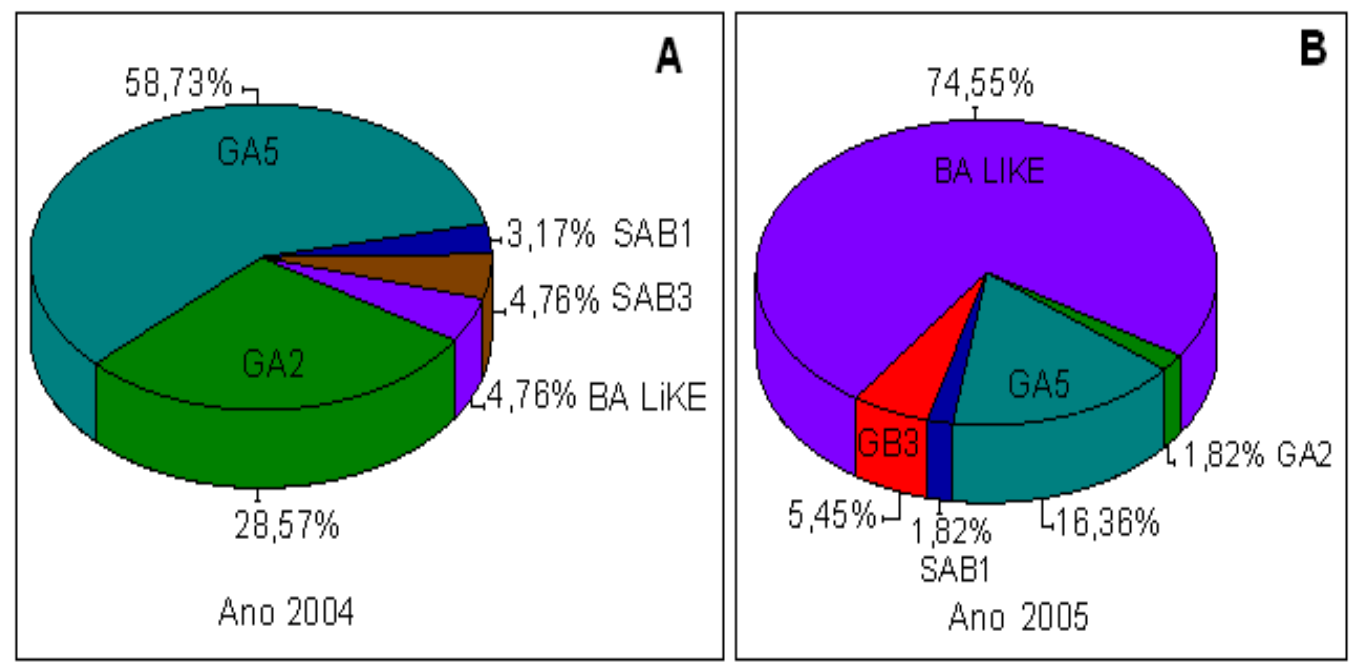

Figura 8 - Distribuição dos genótipos por anos de surtos 2004 (A) e 2005(B), obtidos pelo seqüenciamento do gene $\mathrm{G}$.

\subsection{Análise filogenética do gene SH}

Um total de 117 amostras (anexo C e D) tiveram o gene SH seqüenciado e foram depositadas no GenBank e alinhadas com sequências obtidas no GenBank, pertencentes ao grupo A (anexo E) e grupo B ((anexo F). ( Cane, et al., 1991, Chen, et al., 2000, Lim, et al., 2003). Verificamos que, embora a divergência de nucleotídeos e aminoácidos entre as seqüências do gene $\mathrm{SH}$ seja menor do que no gene G, a análise filogenética separou as amostras do grupo A em dois clados distintos e coincidentes com a genotipagem a partir do gene G. Figura 9. Tabela 3. 


\section{ÁRVORE DO GENE SH GRUPO A}

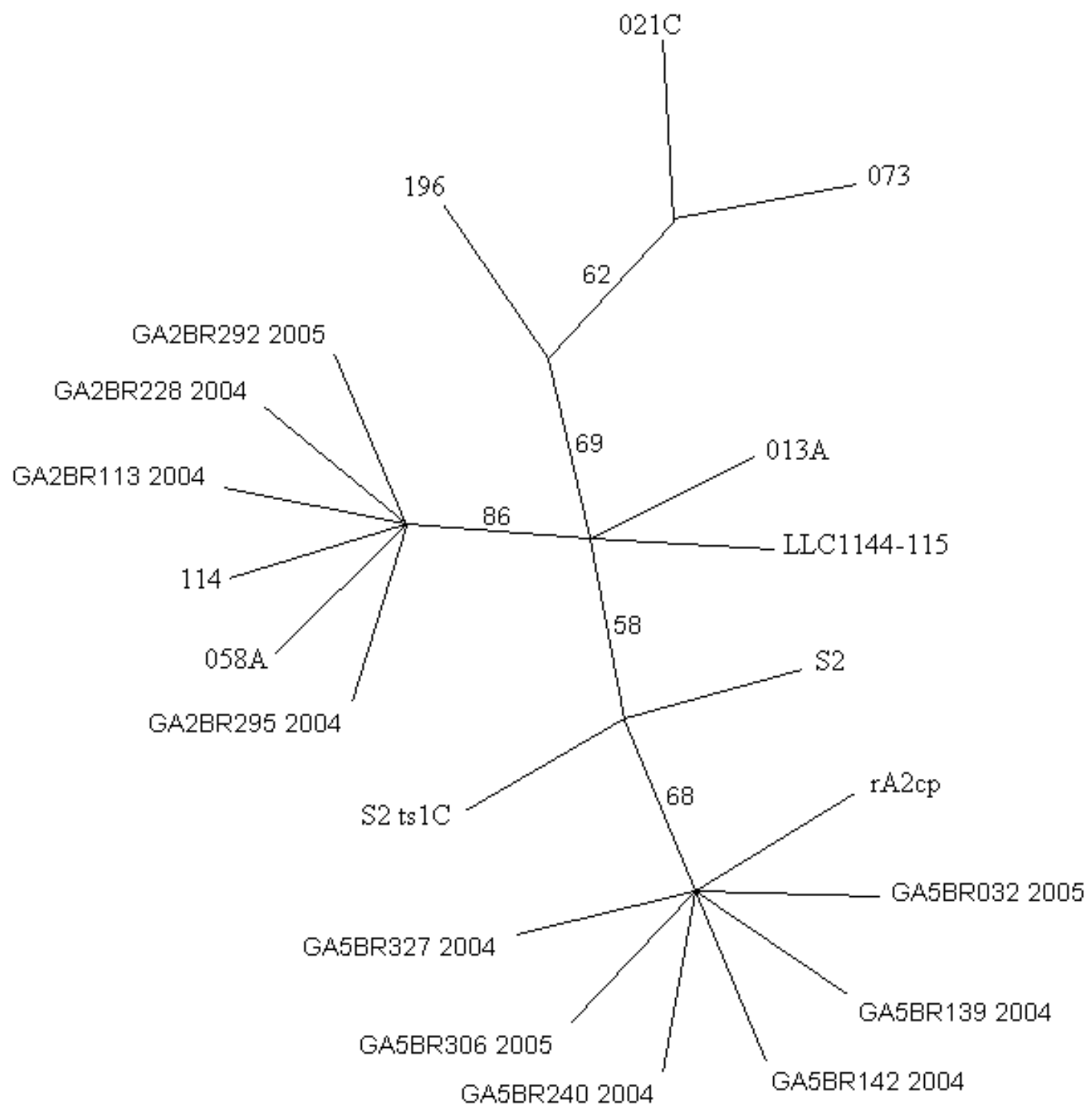

Figura 9 - Análise filogenética do gene SH grupo A com 195 nucleotídeos. Sequiências isoladas originalmente no Brasil (BR acesso GenBank EU109312 - EU109376) comparadas com sequiências disponíveis no GenBank. Topologia da árvore obtida pela análise filogenética do gene SH das amostras brasileiras, utilizando o critério de máxima verossimilhança MV. O valor de Bootstrap está demonstrado sobre os ramos. 
A análise filogenética do gene $\mathrm{SH}$ revelou que as amostras do grupo B agruparam-se em diferentes clusters, os quais foram correspondentes a genotipagem pelo gene G, BA-LIKE, que surgiu recentemente no Brasil). E as amostras pertencentes aos genótipos SAB1, SAB3 e GB3. (Tabela 3, Figura 10).

\section{ÁRVORE DO GENE SH GRUPO B}

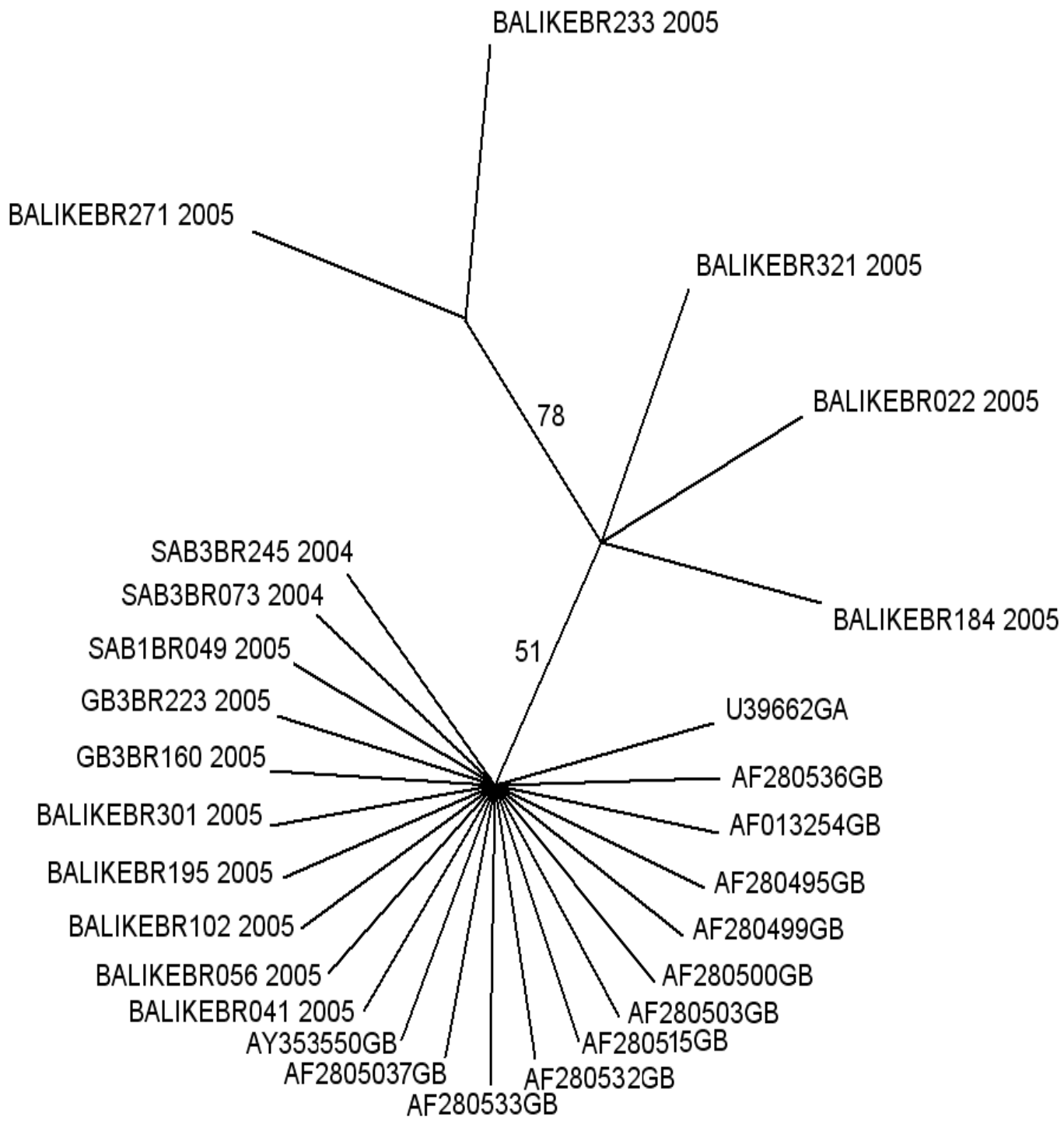

Figura 10 - Análise filogenética do gene SH genótipo B. Seqüências isoladas originalmente no Brasil (BR acesso GenBank EU109377 - EU109425), comparadas com seqüências disponíveis no GenBank, foram utilizadas para construir a árvore filogenética. O valor de Bootstrap obtido por distância está demonstrado sobre os ramos. 
Portanto, o resultado obtido pela análise filogenética dos dois genes $\mathrm{G}$ e $\mathrm{SH}$ realizada com as amostras do grupo A e B foi coincidente, para a genotipagem do grupo A, porém um pouco divergente para o grupo B.

\subsection{Sequências de nucleotídeos e aminoácidos}

As sequências deduzidas de aminoácidos do gene SH do grupo A mostraram-se conservadas, apresentando de 0 a 2 substituições de aminoácidos quando comparadas com a cepa A2 (isolada em 1961) - Figura 11. Das 64 amostras sequenciadas, 40 (87\%) apresentaram 4 mutações silenciosas e apenas 3 apresentaram mutações não conservativas. Entretanto, algumas alterações de nucleotídeos e aminoácidos parecem representar substituições específicas para cada um dos genótipos do grupo A (GA2 e GA5). Foram observadas 4 assinaturas genéticas características do genótipo GA2 nos nucleotídeos 21, 71, 91, 135, sendo que a assinatura correspondente ao nucleotídeo 91 leva a uma troca de (Citocina por Adenina) com uma substituição correspondente de (Leucina pelo Isoleucina). Quanto ao genótipo GA5, somente foi observado uma assinatura genética no nucleotídeo 66 sem trocas de aminoácidos. Figuras 11A e 11B. Quanto ao grupo B Figura 12A e 12B verificamos que todas as 53 amostras analisadas apresentaram mutações nos resíduos 27 (Prolina para Leucina) e 57 (Leucina para Glutamina) quando comparadas com a cepa CH18537 (isolada em 1962) e a média de substituições de aminoácidos nas amostras foi de 2 a 4. 
11A A.2
GA.5_BR327_2004
GA5_BR306_2005 GA5_BR240-2004 GA5 BR142 2004 GAS BR139-2004 GA2_BR295_2004 GA2_BR292_2005 GA2_BR228_2004 GA2 BR113-2004

$11 \mathrm{~A}$ cont.

A.2 GA5_BR306_2005 GA5 BR2 $40-2004$ GA.5_BR139-2004 GA5_BR032_2005 GA2 _BR295_2004 GA2_BR292-2005 GA.2-BR228-2004 11B

A.2 GA.5_BR306-2005 GA5_BR240-2004 GA5_BR142-2004 GA5_BR139_2004 GA2_BR295_2004 GA2_BR292_2005 GA2_BR228_2004

Figura 11 -Alinhamento de 195 nucleotídeos do gene SH de amostras brasileiras de RSVA. As bases estão representadas apenas quando diferem da amostra referência A2. Em negrito estão representadas as mutações sileciosas ocorridas em todas as sequiências brasileiras quando comparadas com a amostra A2 (isolada em 1961). As demais bases identificadas em vermelho representam substituições específicas verificadas nas amostras brasileiras relacionadas à classificação nos diferentes genótipos (GA2 e GA5). As bases sublinhadas representam substituições específicas verificadas em amostras de diferentes localidades relacionadas à classificação em diferentes genótipos. Figura $11 B$ - Alinhamento das seqüências de aminoácidos deduzidas do gene SH de amostras do grupo A isoladas no Brasil. (*) corresponde ao stop codon de cada seqüência. 
$12 \mathrm{~A}$

4.A
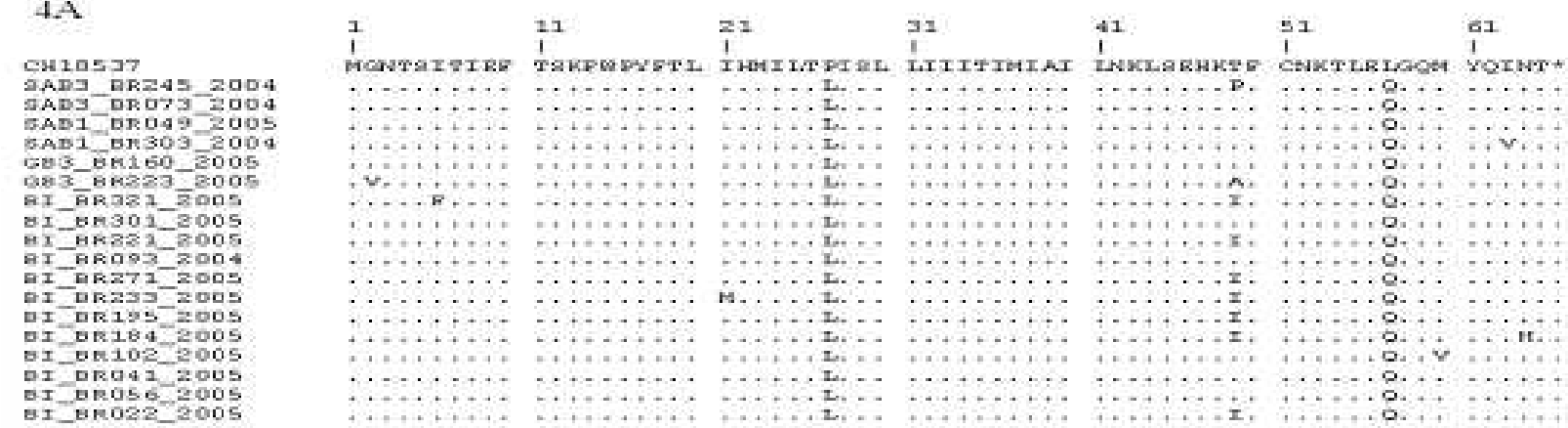

$4 \mathrm{~B}$

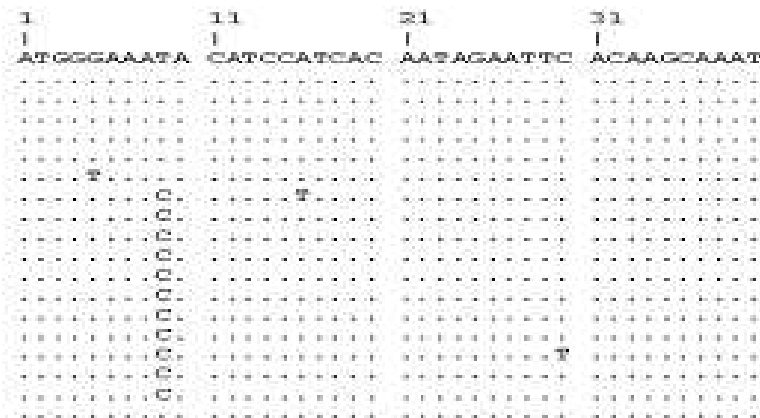

$41 \quad 51$

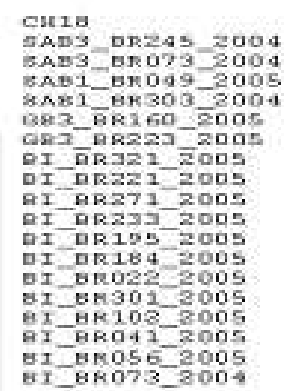

\begin{abstract}
211
\end{abstract}
281

131

141

$15: 7$

261

$x>1$

101

102

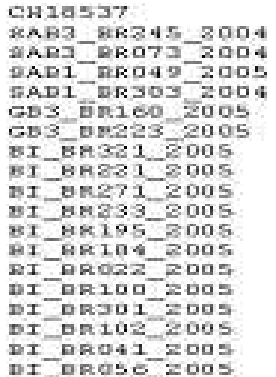

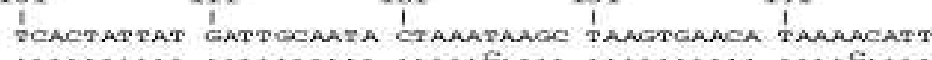

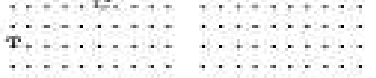

X:P:

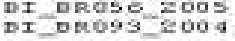

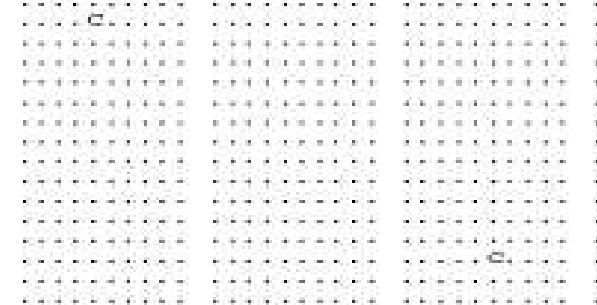

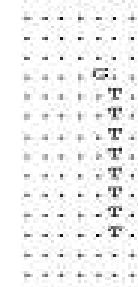
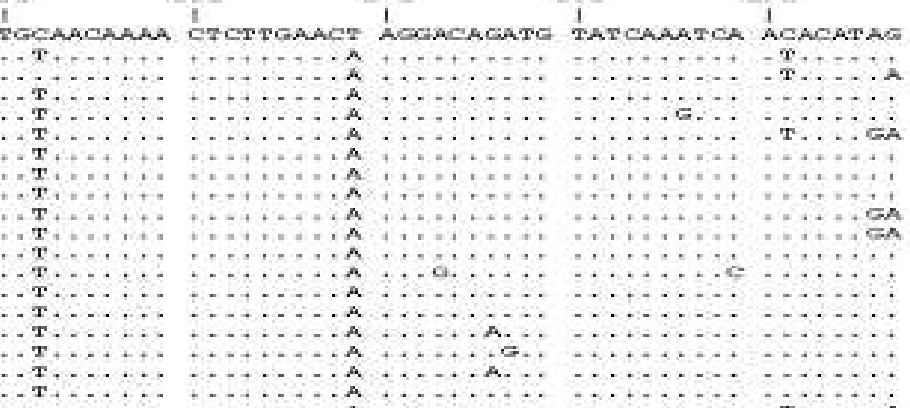

Figura 12- Alinhamento de 198 nucleotídeos do gene SH de amostras brasileiras RSVB. Em negrito estão representadas as mutanções sileciosas ocorridas em todas as seqüências brasileiras quando comparadas com a amostra CH18537 (isolada em 1961). Figura 12A - alinhamento da sequências de aminoácidos deduzidas do gene SH de amostras do grupo B isoladas no Brasil. (*) corresponde ao stop codon de cada seqüência Figura 12B. 


\section{DISCUSSÃO}

O Vírus Respiratório Sincicial Humano (VSRH) é responsável por surtos epidêmicos anuais bem definidos, sendo que o número de infecções causado por esse patógeno vem aumentando todos os anos, consumindo milhões de dólares em cuidados com saúde (Tekkanat, et al., 2001; Collins, et al., 2001). Também apresenta alta taxa de mortalidade em crianças com imunodeficiência congênita e/ou induzida por quimioterapia contra câncer (Hall, et al., 2001; Collins e Graham., 2008). É o agente viral mais frequentemente relacionado a infeccões do trato respiratório inferior em bebês e crianças até 2 anos (Vieira, et al., 2001; Collins, et al., 2001; Zlateva, et al., 2005).

Muitos são os métodos utilizados para estudar a variabilidade genética do vírus VSRH, dentre elas: o ensaio de proteção à ação da Ribonuclease (Cristina, et al., 1990), reação em cadeia pela polimerase após transcrição reversa (RT-PCR), (Zheng, et al., 1996), a análise por enzima de restrição (RFLP), (Jonhson 1987; Sullender, et al., 1991). Sequenciamento dos genes $F, N, S H, P$, e G e reação em cadeia pela polimerase (PCR), estes métodos confirmaram a existência de dois grupos distintos de vírus sincicial respiratórios de A e B (Cane, et al., 1991; Sullender, et al., 1991; Peret, et al., 1998).

Cane e Pringler (1991) utilizaram seqüência parcial de nucleotídeos e o mapeamento de restrição para analisar os produtos da PCR dos genes SH e N respectivamente. Ao analisar 12 amostras isoladas entre os anos de 1956 e 1989 revelaram haver certa variabilidade entre os dois grupos A e B. Foram identificadas, desta forma, diferentes linhagens, denominadas genótipos, dentro de cada grupo: SH1-6 para o grupo A e NP1 e NP3 para o grupo B; verificou-se ainda, a co-circulação destas durante um surto epidêmico em Birmingham e, posteriormente, em várias localidades do mundo, incluindo Alemanha, Finlândia e Uruguai, demonstrando que vírus isolados em deferentes regiões podem ser similares (Cane e Pringle, 1991; Cane, et al., 1994). A análise filogenética das sequiências do gene $G$ das amostras representantes dos genótipos acima, gerou uma árvore com clusters semelhantes aos obtidos na análise do gene SH, confirmando a genotipagem inicial (Cane, et al., 1991).

Vários estudos, inicialmente baseados apenas nas propriedades antigênicas, foram realizados no sentido de entender o padrão de circulação do VSRH. A partir destes estudos pode-se concluir que ocorre a co-circulação dos grupos durante os surtos 
e a variação do padrão de circulação de diferentes comunidades durante o mesmo ano, não sendo encontrada uma cepa epidêmica única (Anderson, et al., 1991).

Em um trabalho de revisão da diversidade genética do VSRH realizado por Sullender (2000), foi demonstrado que, embora as nomenclaturas adotadas fossem diferentes, os agrupamentos dos isolados de VSRH em genótipos são muito similares entre as diferentes publicações sobre o assunto. Portanto amostras designadas por Peret, et al., 1998), como GA1 - GA5 apresentam correspondência com a genotipagem baseada no sequenciamento parcial dos genes SH e G de (Cane e Pringle, 1991; Cane, et al., 1991), SHL1-SHL5. Assim GA1 corresponde a SHL5, GA3 a SHL1-3 e 4 GA5 a SHL2 (Cane, 2001).

Em nosso trabalho, foram colhidas amostras de crianças atendidas e internadas no Hospital Universitário da USP-SP, no período de (janeiro de 2004 a dezembro de 2005), para análise da diversidade genética pela comparação das proteínas G e SH. Foram utilizadas amostras previamente sequenciadas e genotipadas pela região G2 da proteína G para comparação e análise filogenética da proteína SH. Foi possível verificar que a circulação do VSRH na cidade de São Paulo obedeceu a uma sazonalidade típica, com um surto anual bem definido, estendendo-se durante os meses de outono e inverno, com pico de incidência ocorrendo nos meses de março a junho (Figura 7).

Verificamos ainda que ocorreu a circulação dos grupos A e B no período estudado, com predominância do grupo A em 2004 e do grupo B em 2005, principalmente o novo genótipo BA-like surgido recentemente (Venter, et al., 2001; Trento, et al., 2003), como mostra o tabela 3. Em termos percentuais os genótipos circularam em igual proporção como mostra a Figura 8.

Nossos dados estão de acordo com a literatura, a qual mostra que a circulação dos grupos A e B podem variar no decorrer dos anos em uma comunidade (Anderson, et al., 1991). Estudo realizado por Botosso (2002) sobre diversidade genética das amostras de VSRH identificadas na cidade de São Paulo, pela análise parcial do gene G, verificou circulação de múltiplas linhagens, 1 ou 2 genótipos predominando a cada ano, o aumento da circulação de alguns genótipos e declínio de outros no decorrer dos anos, corroborando dados da literatura (Seki, et al., 2001; Venter, et al., 2001). Circulação semelhante foi encontrada na China, onde as amostras do grupo A foram predominantes sobre o grupo B, no ano de 2004 (Zhang, et al., 2007).

Um estudo realizado na Índia nos anos 2003 a 2005 mostra uma alta prevalência do grupo A em 2004. Segundo este estudo, 77\% dos casos estudados 
pertenciam ao grupo A, enquanto que em 2005 houve um declínio da incidência deste grupo e aumento no número de prevalência para o grupo BA-like (Parveen, et al., 2006). Circulação semelhante foi descrita na cidade de Campinas no Estado de São Paulo, onde foram encontrados os mesmos genótipos que circularam na cidade de São Paulo com os mesmos percentuais (Silva, et al., 2008).

A topologia das árvores filogenéticas geradas pelos critérios de Máxima Verossimilhança (MV) e distâncias evolutivas foi bastante semelhante para os dois grupos (A e B) e para os dois genes estudados, G e SH.

As amostras brasileiras foram genotipadas pela comparação com sequiências parciais do gene $\mathrm{G}$ de amostras isoladas em outras localidades, previamente atribuído aos genótipos específicos (Zlateva, et al., 2004; Matheson, et al., 2006; Peret, et al., 1998 e 2000; Venter, 2001). Identificamos assim 2 genótipos dentro do grupo A, GA2 e GA5 e 4 dentro do grupo B, GB3, SAB3, SAB1 e BA-like. Houve a co-circulação dos genótipos durante os 2 anos, sendo que em 2004 houve predominância do GA5 sobre os demais (Tabela 3), com declínio de circulação no ano seguinte e sendo substituído por um novo genótipo, GB3 com inserção. Como observado por outros autores o fenômeno drift, indicando certa pressão na resistência imunológica da população (Peret, et al., 1998; Choi e Lee, 2000; Venter, et al., 2001; Cane et al. 1994; Seki et al. 2001; Botosso, et al., 2009).

Em 1999 na cidade de Buenos Aires foram isoladas as primeiras amostras com inserção de 60 nucleotídeos (Trento, et al., 2003), e posteriormente foram isoladas amostras em diversos lugares do mundo como, Japão, Quênia, Canada, Nova Zelandia e Bélgica (Scott, et al., 2004; Nagai, et al., 2004; Zlateva, et al., 2005; Mathenson, et al., 2006) dando origem ao um novo genótipo BA-like derivado do GB3. Este genótipo, foi predominante em 2005 no Estado de São Paulo, tendo sido confirmado a sua cocirculação no mundo (Botosso, et al., 2009).

O sequenciamento do gene SH das amostras clínicas brasileiras demonstrou que o mesmo é altamente conservado, com poucas variações de nucleotídeos e aminoácidos em comparação com as cepas A2 e CH18537, isoladas há mais de trinta anos. Das 64 seqüências obtidas do grupo A, 43 não apresentavam nenhuma alteração de aminoácidos em relação ao protótipo, e as demais sequências apresentaram apenas de 1 a 2 alterações. A pouca variabilidade desse gene foi descrita, previamente, por outros autores (Cane, et al., 1991; Chen, et al., 2000; Lim, et al., 2003), levantando a hipótese de que, embora a função da proteína não esteja totalmente esclarecida, ela seja essencial 
para a infecção clínica, representando um fator de patogenicidade ou um fator para a estabilização do envelope viral na natureza (Bukreyev, et al., 1997; Whitehead, et al., 1999; Chen, et al., 2000). Entretanto, foi possível realizar a genotipagem do VSRH sendo observadas alterações de nucleotídeos e aminoácidos que caracterizaram os dois genótipos encontrados (Figura 11A e 11B). Quando essa análise foi expandida para sequências de amostras isoladas em outras localidades, Estados Unidos e Singapura, as únicas assinaturas genéticas identificadas foram referentes às posições 72(C-A) e 135 (T-C), ambas causando mutações silenciosas.

O gene SH do grupo B também se apresentou altamente conservado, sendo que 17 amostras não apresentaram alterações de aminoácidos em relação ao protótipo CH18537 (Figura 12A e 12B). Entretanto verificamos que ocorreram duas alterações de aminoácidos em todas as amostras brasileiras, previamente descritos na literatura, que correspondem ao resíduo 27 (Pro $\rightarrow$ Leu) e ao resíduo 57 (Leu $\rightarrow$ Glu). (Chen, et al., 2000). Das demais mutações verificamos que apenas duas foram não conservativas, na posição 49 (treonina foi alterada para Alanina, Prolina ou Isoleucina) e na posição 64 (Asp $\rightarrow$ His). Algumas dessas alterações foram descritas por outros autores, (Chen, et al., 2000; Cane, et al., 1991; Lim, et al., 2003), demonstrando que o vírus apresenta circulação mundial, com cepas muito próximas circulando em diferentes localidades. Diferentemente da análise filogenética do gene $\mathrm{G}$ a análise do gene $\mathrm{SH}$ das amostras do grupo B não definiu bem os clados por nenhuma das metodologias adotadas (MV ou distância evolutiva). Entretanto, verificamos que as amostras identificadas como BAlike, que possuíam inserção de 60 nucleotídeos, agruparam em um mesmo clado, próximo ao GB3 e SAB3, demonstrando uma origem comum e que uma análise de outros genes de cepas pertencentes a esse novo genótipo pode permitir a verificação de outras alterações características que possam ter conferido ao vírus uma vantagem evolutiva, imunológica ou não, permitindo sua rápida disseminação pelo mundo.

Assim, apesar de algumas regiões da proteína SH da cepa A2 já terem sido identificadas como importantes epitopos para células B e T (Nicholas, et al., 1988), a variabilidade genética observada entre amostras isoladas em diferentes localidades e em anos diferentes $(1999,2000,2004,2005)$ foi mínima, sugerindo que a importância dessa proteína não esteja relacionada aos mecanismos de escape imunológico do vírus, como ocorrido com a proteína G, mas sim com algum outro mecanismo, como na patogenicidade viral, no seu ciclo infeccioso, sendo portanto, uma forte candidata para estudos como alvo de drogas antivirais. 


\section{DISCUSSÃO}

Ao analisar a circulação dos genótipos nos anos de 2004 e 2005 a partir da genotipagem pela região da proteína $\mathrm{G} 2$ comparada ao gene $\mathrm{SH}$, pode-se concluir que:

1 Houve predominância do grupo A em 2004 e do grupo B em 2005, com o surgimento de um novo genótipo BA-Like;

2 Verificou-se que embora a divergência de nucleotídeos e aminoácidos entre as sequências do gene $\mathrm{SH}$ sejam menores do que no $\mathrm{G}$, a análise filogenética dividiu as amostras do grupo A em dois clados distintos GA2 e GA5, bem como as amostras do grupo B, foram dividas em SAB1, SAB3, GB3, e BA-Like e que são coincidentes com a genotipagem a partir do gene $\mathrm{G}$. 


\section{REFERÊNCIAS BIBLIOGRAFICAS*}

Abels S, Nadal D, Stroehle A, Bossart W. Reliable Detection of Respiratory Syncytial Virus Infection in Children for Adequate Hospital Infection Control Management. J. Clin. Microbiol. 2001;39: 3135-39.

Anderson LJ, Hierholzer JC, Tsou C, Hendry RM, Fernie BF, Stone Y, McIntosh K. Antigenic characterization of respiratory syncytial virus stains with monoclonal antibodes. J Infect Dis. 1985;151:626-33.

Anderson LJ, Parker RA, Strikas RL. Association between respiratory syncytial virus outbreaks and lower respiratory tract deaths of infants and young children. J Infect Dis. 1990; 161:640-46.

Anderson LJ, Hendry RM, Pierik LT, Tsou C, Mcintosh K. Mulicenter study of strains of respiratory syncytial virus. J Infect Dis. 1991;163:687-92.

Arbiza J, Delfraro A, Frabasile S. Molecular epidemiology of human respiratory syncytial virus virus in Uruguay: 1985-2001 - a review. Mem Inst Oswaldo Cruz. 2005;100:221-30.

Arbiza J, Berois M, Delfraro A, Frabasile S, Mitoma FD, Milk R, et al. Genetic characterization of respiratory syncytial viruses isolated from consecutive acute respiratory infections in a HIV infected child. J Clin Virol. 2006;35:41-5.

Arens MQ, Swierkosz EM, Schimidt RR, Armstong T, Rivetna KA. Enhanced isolation of respiratory syncytial virus in cell culture. J Clin Microbiol. 1986; 4:800-2.

Atreya PA, Peeples M, Collins PC, - The NS1 Protein of Human Respiratory Syncitial Virus Syncitial Virus is a Potente inibitor of Minigenome Transcription and RNA replication. J Virol. 1998;72:1452-61.

Barik S. The structure of the $5^{\prime}$ terminal cap of the respiratory syncytial virus mRNA. J Gen Virol. 1993;74:485-90.

Barik S. Development of gene-specific double-stranded RNA drugs. Ann Med. 2004;36:540-51.

Beeler JÁ, Coeling K. Neutralization epitopes of respiratory syncytial vírus:effect of mutation upon fusion. J Virol. 1989;63:2941-50.

Blanc A, Delfraro A, Frabasile S, Arbiza J. Genotypes of respiratory syncytial virus group B indentified in uruguay. Arch Virol. 2005;150:603-3.

Bolt $\mathrm{G}$, Cleavage of the respiratory syncytial virus fusion protein is required for its surface expression: role of furin. Virus Res. 2000;68:25-33.

\footnotetext{
* De acordo com:

International Committee of Medical Journal Editors. Uniform requirements for manuscripts submitted to Biomedical Journal: sample references. Available from: http://www.icmje.org [2007 May 22].
} 
Botosso VF. Diversidade genética da glicoproteína $\mathrm{G}$ do vírus respiratório sincicial humano (HRSV) entre amostra isoladas na cidade de São Paulo, 1995-1998 [tese (doutorado)]. São Paulo: Instituto de Ciências Biomédicas da Universidade de São Paulo; 2002.

Botosso VF, Zanotto PM, Ueda M, Arruda E, Gilio AE, Vieira SE, Stewien KE, Peret TC, Jamal LF, Pardini MI, Pinho JR, Massad E, Sant'anna OA, Holmes EC, Durigon EL. VGDN Consortium. Positive selection results in frequent reversible amino acid replacements in the $G$ protein gene of human respiratory syncytial virus. PLoS Pathog. 2009;5:1-11.

Bryce J, Boschi-Pinto C, Shibuya K, Black RE. WHO Child Health Epidemiology Reference Group. WHO estimates of the causes of death in children. Lancet. 2005;365:1147-52.

Brouard J, Freymuth F, Constantini S, Petitjean J, DE Schrevel G, Duhamel JF. Prévalence et aspects cliniques de iinfection par less sous-types A et B du virus respiratoire synscytial. observatin de 8 Épidémies Consécutives de 1982 a 1990. Arch Fr Pediatr. 1993; 50:639-643.

Broughton S, Greenough A. Effectiveness of drug therapies to treat or prevent respiratory syncytial virus infection-realated morbidity. Expert Opin Pharmacother. $2003 ; 4 ; 1801-8$.

Bukreyev A, Whitehead SS, Murphy BR, Collins PL. Recombinant respiratory syncytial virus from which the entire $\mathrm{SH}$ gene has been deleted grows efficiently in cell culture and exhitis site-specific attenuation in the respiratory tract of mouse. J Virol. 1997;71:8973-8982.

Candeias JA Isolation of the respiratory syncytial virus from children with acute respiratory infections. Rev Inst Med Trop Sao Paulo. 1967;9:27-30

Cane PA, Mathews DA, Pringle CR. Identification of variable domains of the attachment $(\mathrm{G})$ protein of subgroup A respiratory syncytial virus. J Gen Virol. 1991;72:2091-96.

Cane PA, Pringle CR. Respiratory syncytial virus heterogeneity during an epidemic: analysis by limited nucleotide sequencing ( $\mathrm{SH}$ gene) and restriction mapping (Ngene). J Gen Virol. 1991;72:349-57.

Cane PA, Matthews DA, Pringle CR Analysis of Respiratory Syncytial Virus Strain Variation in Successive Epidemics in One City. J Clin Microb. 1994;32:1-4.

Cane PA. Molecular epidemiology of Respiratory Syncytial Virus. Rev Med Virol. 2001; 11:103-16.

Chanock RM, Roizaman B, Myers R. Recovery from infants with respiratory illness of a virus related to chimpanzee coryza agent. isolation, properties and characterization. Am $\mathrm{J}$ Hyg. 1957; 66:281-90. 
Chanock RM, Vargosko AJ. Respiratory syncytial virus. I virus recovery and other observations during 1960 outbreak of bronchiolitis, pneumonia and minor respiratory diseases in children. J Am Med Assoc. 1961;176:647-53.

Chen MD, Vazquez M, Buonocorel L, Kahn JS. Conservation of the respiratory syncytial virus SH gene. J Infect Dias. 2000,182:1228-33.

Cheng X, Park H, Zhou H, Jin H. Over expression of the M2-2 protein of respiratory syncytial virus inhibits viral replication. J Virol. 2005;79:13943-52.

Chidgey SM, Broadley KJ. Respiratory syncytial virus infections: characteristics and treatment J Pharm Pharmacol. 2005;57:1371-81.

Choi E, Lee H. Genetic diversity and molecular epidemiology of the G protein of subgroups A and B of respiratory syncytial viruses isolated over 9 consecutive epidemics in Korea. J Infect Dis. 2000;181:1547-56.

Coates HV, Alling DW, Chanock RM. An antigenic analysis of respiratory syncytial virus by plaque reduction neutralization test. Am J Epidemiol. 1966;89:299-313.

Collins PL, Mcitosch K, Chanock RM. Respiratory syuncytial virus. ln: Fields BN. Fields Virology. Philadelphia: Lippincott-Raven publishers; 1996. p. 1313-51.

Collins PL, Chanock RM, Murphy BR. Respiratory syncytial virus. In: Knipe DMP, Howley, M, Griffin DE, Lamb RA, Martin MAB. Fields Virology. Philadelphia: Lippincott-Raven publishers; 2001. p. 1443-86.

Collins PL, Graham BS. Viral and Host Factors in Human Respiratory Syncytial Virus Pathogenesis. J Virol. 2008;82:2040-55.

Cowton VM, McGivern DR, Fearns R. Unravelling the complexities of respiratory syncytial virus RNA synthesis. J Gen Virol. 2006;87:1805-21.

Cristina J, Lopez JA, Garcia-Barreno B, Garcia J, Portela AA. Analysis of Genetics Variability in Human Respiratory Syuncytial Virus by the RNAse A Mismatch Cleavage Method: Subtype and divergence and Heterogeneity. Virology. 1990;174:126-34.

D'Elia C, Siqueira MM, Portes AS, Sant'Anna CC. Infecções do trato respiratório inferior pelo vírus sincicial respiratório em crianças Hospitalizadas menores de um ano de idade. Rev Soc Bras Med Trop. 2005;38:7-10.

DeVincenzo J. Passive antibody prophylaxis for rsv. Pediatr Infect Dis J. 2008;27:6970.

DeVincenzo JP. A new direction in understanding the pathogenesis of respiratory syncytial virus bronchiolitis: how real infants suffer. J Infect Dis. 2007;195:1126-36.

Englund JA, Piedra PA, Jewell A, Patel K, Baxter BB, Whimbey E. Rapid diagnosis of respiratory syncytial virus infections in immunocompromised adults. J Clin Microbiol. 1996; 34:1649-53. 
Erdman DD, Weinberg GA, Edwards KM, Walker FJ, Anderson BC, Winter J, González M, Anderson LJ. GeneScan reverse transcription-PCR assay for detection of six common respiratory viruses in young children hospitalized with acute respiratory illness. J Clin Microbiol. 2003;41:4298-303

Falsey AR. Respiratory Syncytial Virus Infections in older Persons. Vaccine. 1998;16:1775-78.

Falsey AR, Wash EE. Respiratory syncytial virus infection in adults. Clin Microbiol Rev. 2000;13:371-84.

Felsenstein J. Confidence limits on phylogenies: an approach using the bootstrap. Evolution. 1985;39:783-91

Freymuth F, Petitjean J, Pothier P, Brouard J, Norby E. Prevalence of respiratory syncytial virus subgroup A and B in France from 1982 to 1990. J Clin Microbiol. 1991;29:653-55.

Fuentes S, Tran KC, Luthra P, Teng MN, He B. function of the respiratory syncytial virus small hydrophobic protein. J Virol. 2007;81:8361-66.

Galiano MC, Palomo C, Videla CM, Arbiza J, Melero JA, Carballal G. Genetic and antigenic variability of human respiratory syncytial virus (groups a and b) isolated over seven consecutive seasons in Argentina (1995 to 2001). J Clin Microbiol. 2005;43:226673.

Galiano MC, Luchsinger V, Videla CM, Souza L, Puch SS, Palomo C, Ricarte C, et al. Intragroup antigenic diversity of human respiratory syncytial virus (group A) isolated in Argentina and Chile. J Med Virol. 2005;77(2):311-16.

Gilca R, De Serres G, Tremblay M, Vachon ML, Leblanc E, Boivin G, et al. Distribution and clinical impact of human respiratory syncytial virus genotypes in hospitalized children over 2 winter seasons. J Infect Dis. 2006; 193:54-58.

Gimenez HB, Cash P, Melvin WT, Monoclonal antibodies to human respiratory syncytial virus and their use in comparison of different virus isolates. J Gen Virol. 1984;65;963-71.

Girard MP, Cherian T, Pervikov Y, Kieny MP. A review of vaccine research and development: Human acute respiratory infections. Vaccine. 2005;23(50):5725-31.

Glezen WP, Taber LH, Frank AL, Kasel JA. Risk of Primary Infection and Reinfection with Respiratory Syncytial Virus. Am J Dis Child. 1986;40:543-46.

Graham BS, Johnson TR, Peebles RS. Immune-mediated disease pathogenesis in respiratory syncytial virus infection. Immunopharmacology. 2000;48:237-47.

Hall CB, Walsh EE, Schnabel KC, Long CE, Mcconnochie KM, Hildreth SW, Anderson LJ. Occurrence of groups A and B of Respiratory Syncytial Virus over 15 years: Associated Epidemiologic and Clinical Characteristics in Hospitalized and Ambulatory Children. J Infect Dis. 1990;1283-90. 
Hall CB, Long CE, Schnabel KC. Respiratory syncytial virus infections in previously healthy working adults. Clin Infect Dis. 2001;33:792-96.

Halstead DC, Todd S, Fritch G. Evalution of five methods for syncytial virus detection. J Clin Microbiol. 1990;28:1021-25.

Hardy RW, Wertz GW. The product of the respiratory syncytial virus M2 gene ORF1 enhances readthrough of intergenic junctions during viral transcription. J Virol. 1998;72:520-26.

Hendricks DA, McIntosh K, Patterson JL. Further characterization of the soluble form of the G glycoprotein of respiratory syncytial virus. J. Virol. 1988;62:2228-33.

Hendry RM, Pierik LT, Mcintosh K. Prevelence of respiratory syncytial virus subgroup cver six consecutive outbreaks: 1981-1987. J Infect Dis. 1989;160:185-90.

Hierholzer JC, Castels E, Banks GG, Bryan JA, Mcewen CT. Sensitivity of NCI-H292 human lung mucoepidermoid cells for respiratory and other human viruses. J Clin Microbiol. 1993;31:1504-1510.

Hills WD, Cooper MR, Bang FB, Dey AK, Shak KV. Respiratory Syncytial Virus Infection in Children in West Bengal. Ind J Med Res. 1971;59:1354-64.

Hornsleth A, Klug B, Nir M, Johansen J, Hansen KS, Chistensen LS, Larsen LB. Severity of Respiratory Syncytial Virus Disease Related to type and Genotype of Virus and to Cytikinevalues in Nasopharyngeal Secretions. Pediatr Infect Dis J. 1998;17:1114-21.

Huang YT, Wertz GW. The genome of respiratory syncytial virus is a negative-stranded RNA that codes for at least seven mRNA species . J Virol. 1982;150-57.

Hu A, Colella M, Tam JS, Rappaport R, Cheng S. Simultaneous detection, subgrouping and quantitation of respiratory syncytial vírus $\mathrm{A}$ and $\mathrm{B}$ by real time PCR. J Clin Microbiol. 2003; 41:149-54.

Johnson PJ, Olmsted RA, Prince GA, Murphy BR, Alling DW, Walsh EE, Collins PL. Antigenic relatedness between glycoproteins of human respiratory virus subgroup A and $\mathrm{B}$ : evatuation of the contribution of $\mathrm{F}$ and $\mathrm{G}$ glycoproteins to immunity. $\mathrm{J}$ Virol. 1987;61:3163-66.

Kamasaki HH, Tsulsumi H, Seki K, Chiba S. Genetic variability of respiratory syncytial virus subgroup B strain isolated during the last 20 years from the same region in Japan: existence of time-dependent linear genetic drifts. Arch Virol. 2001;146:457-66.

Karron RA, Buonagurio DA, Georgia AF, Whitehead SS, Adamas JE. Respiratory syncytial virus (RSV) SH and G proteins are not essential for viral replication in vitro: clinical evaluation and molecular characterization of a cold-passage, attenuated RSV subgroup B mutant. Proc Natl Acad Sci USA. 1997;94:13961-66. 
Kaplan NM, Dove W, Abd-Eldayem WS, Abu-Zeid FA, Shamoon EH, Hart CA. Molecular Epidemiology and Disease Severity of Respiratory Syncytial Virus in Relation to Other

Potential Pathogens in Children Hospitalized With Acute Respiratory Infection in Jordan. J Med Virol. 2008;80:168-74.

Kellogg JA. Culture vs direct antigen assays for detection of nicrobial pathogens fromlower respiratory tract specimens suspected of containing the respiratory suycytial virus. Arch Pathol Lab Med. 1991;115:399-11.

Kingsbury DW. Paramyxoviridae and their replication. In: Fields BN. Virology. Philadelphia: Lippincott-Raven Publishers; 1990. p. 945-62.

Koneman EW, Allen SD, Janda WM, Schereckenberger PC, Winn WC. Diagnóstico das infecções causadas por vírus, Chlamydia, Rickettsia e Microorganismos relacionados. In: Cury AM, editor. Diagnóstico microbiológico. 5 ed. Rio de Janeiro: Medsi; 2001. cap 21 p. 1187-302. Color atlas and Textbook of Diagnostic Microbilogy.

Levine S, Klaiber-franco R, Paradiso PR, Demonstration that glycoprotein G is the attachament protein of respiratory syncytial virus. J Gen Virol. 1987;68;2521-24.

Lim CS, Kumararasinghe G, Chow VTK. Sequence and phylogenetic analysis of SH, G and $\mathrm{F}$ genes and proteins of human respiratory syncytial virus isolates from Singapore. Acta Virol. 2003;47:97-104.

Low KW, Tan T, Ng K, Tan BH, Sugrue RJ. The RSV F and G glycoproteins interact to form a complex onthe surface of infected cells. Biochem Biophys Res Commun. 2008;366:308-13.

Maggon k, Barik S. New drugs and treatment for respiratory syncytial virus. Rev Med Virol. 2004;14:149-68.

Manson SW, Lawetz C, Gaudette Y, Dô F, Scouten E, Lagacé L, Simoneau B, Liuzzi M. Polyadenylation-dependent screening assay for respiratory syncytial virus RNA transcriptase activity and identification $o$ fan inhibitor. Nucleic Acids Res. 2004;32:4758-67.

Martinez I, Melero JA. Binding of human respiratory syncytial virus to cells: implication of sulfated cell surface proteoglycans. J Gen Virol. 2000;81:2715-22.

Matheson JW, Rich FJ, Cohet C, Grimwood K, Huang QS, Penny D, Hendy MD, Kirman JR. Distinct patterns of evolution between respiratory syncytial virus subgroups A and B from New Zealand isolates collected over thirty-seven years. J Med Virol. 2006;78(10):1354-64.

Matthews JM, Young TF, Tucker SP, Mackay JP. The core of the respiratory syncytial virus fusion protein is a trimeric coiled coil. J Virol. 2000;74:5911-20. 
Mazzulli T, Peret TC, McGeer A, Cann D, MacDonald KS, Chua R, Erdman DD, Anderson LJ. Molecular characterization of a nosocomial outbreak of human respiratory syncytial virus on an adult leukemia/lymphoma ward. J infect Dis. 1999; 180:1686-89.

Mcintosh K. Respiratory syncytial virus infections in infants and children: diagnosis and treatment. Pediatr Res. 1987;9:191-96.

Mcintosh K, Chanock RM. Respiratory syncytial virus. In: Fields BN, Knipe DM, Chanock RM, Hirsch MS, Melnick JL, Monath TP, Roizaman B, editors. Fields Virology. 2nd ed. New York: Raven Press; 1990. p. 1045-74.

Melero JA, Garcia-Barreno B, Martinez I, Pringle CR, Cane PA, Antigenic structura, evolution and immunobiology of human respiratory syncytialvirus attachment $(\mathrm{G})$ proteins. J Gen Virol. 1997;66:2411-18.

Mink MA, Stec DS, Collins PL. Nucleotide sequence of the $3^{\prime}$ leader and $5^{\prime}$ trailer regions of human respiratory syncytial virus genomic RNA. Virology. 1991;185:615-24

Morris JA, Bolunt RE, Savage RE. Recovery of cytopathogenic agent from chimpanzees with coryza. Proc Soc Exp Med. 1956;92:544-50.

Moura FEA, Blanc A, Frabasile S, Delfraro A, Sierra MJ, Tome T, et al., Genetic diversity of respiratory syncytial virus isolated during an epidemic period from children of northeastern Brazil. J Med Virol. 2004;74:156-60.

Moura FE, Nunes IF, Silva GB Jr, Siqueira MM. Respiratory syncytial vírus infection in Northeastern Brazil: seasonal trends and general aspects. Am J Trop Med Hyg. 2006;74:165-7.

Mufson MA, Belshe RB, Orvell C, Norrby E. Respiratory syncytial virus epidemics: variable dominance of subgroup A and B strains among children, 1981-1986. J Infect Dis. 1988;157: 143-8.

Mufson MA, Rafnar B, Akerlind-stopner C, Orvell RB, Norrby E. A Single-scason epidemic with respiratory syncytial virus subgroup B2 during 10 epidemic years, 1978 to 1988. J Clin Microbiol. 1991;29:162-5.

Nagai K, Kamasaki H, Kuroiwa Y, Okita L, Tsutsumi H. Nosocomial outbreak of respiratory syncytial virus subgroup B variants with 60 nucleotides-duplicated $\mathrm{G}$ protein gene. J Med Virol. 2004;74:161-5.

Nascimento CA, Sousa TS, Moraes CT, Vedovello D, Durigon EL, Botosso VF et al. One-step reverse transcriptase polymerase chain reaction for the diagnosis of respiratory syncytial virus in children. J Virol Methods. 2008;148:115-19.

Nicholas JA, Mitchell MA, Levely ME, Rubino KL, Kinner JH, Harn NK, Smith CW. Mapping of an antibody-binding site and a T-cell-stimulating site on the 1A protein of respiratory syncytial virus. J Virol. 1988;62:4465-73. 
Ong GM, Wyatt DE, O'Neill HJ, McCaughey C, Coyle PV. A comparison of nested polymerase chain reaction and immunofluorescence for the diagnosis of respiratory infections in children with bronchiolitis, and the implications fora cohorting strategy. $\mathrm{J}$ Hosp Infect. 2001;49:122-28.

Parveen S, Sullender WM, Fowler K, Lefkowitz EJ, Kapoor SK, Broor1 S. Genetic variability in the $\mathrm{G}$ protein gene of group $\mathrm{A}$ and $\mathrm{B}$ respiratory syncytial viruses from India. J Clin Microbiol. 2006;3055-64.

Peret TCT, Hall CB, Schanabel KC, Gollub JA, Anderson LJ. Circulation patterns of genetically Distinct Group A and B strains of human of respiratory syncytial virus In A community. J Gen Virol. 1998;79:2221-29.

Peret TC, Hall CB, Hammond GW, Piedra PA, Storch GA, Sullender WM, Tsou C, Anderson

LJ. Circulation patterns of groups group A and B human respiratory syncytial virus genotypes in 5 communities in north America. J Infect Dis. 2000;181:1891-6.

Perini AP, Barbosa ML, Botosso VF, de Moraes CT, Stewien KE, Durigon EL. Compararison of Hela-I, Hep-2 and NCI-H292 cell lines for the isolation of human respiratory syncytial vírus (HRSV). J Virol Methods. 2007;146(1-2):368-71.

Rixon HWM, Brown G, Sugrue RJ. Multiple glycosilated forms of the respiratory syncytial virus fusion protein are expresses in virus-infected cell. J Gen. Virol. 2002;83:61-6.

Rovida F, Percivalle E, Zavattoni M, Torsellini M, Sarasini A, Gerna G. Monoclonal antibodies versus reverse transcription-PCR for detection of respiratory viruses in a patient population with respiratory tract infections admitted to hospital. J Med Virol. 2005;75:336-47.

Roberts SR, Lichtenstein D, Ball A, Wertz GW. The membrane-associated and secreted forms of the respiratory syncytial virus attachment glycoprotein $\mathrm{G}$ are synthesized from alternative initiation codons. J. Virol. 1994;68:4538-4546.

Russi JC, Chiaparelli H, Montano A, Etorena P, Hortal M. Respiratory sncytial virus subgroups and pneumonia in children. Lancet. 1989;2:1039-40.

Sanz MC, Kew OM, Anderson LJ. Genetic Heterogeneity of the Attachment Glycoprotein G among group A Respiratory Syncytial Viruses. Virus Res. 1994;33:20317.

Sarkkinen HK, Halonen PE, Arstila PP, Salmi AA. Detection of respiratory syncytial, parainfluenza type 2, and adenovirus antigens by radioimmunoassay and enzyme immunoassay on nasopharyngeal specimens from children with acute respiratory disease. J Clin Microbiol. 1981; 13:258-265.

Sato M, Saito R, Sakai T, Sano Y, Nishikawa M, Sasaki A, Shobugawa Y, Gejyo F, Suzuki H. Molecular epidemiology of respiratory syncytial virus infections in children 
with acute respiratory symptoms in a community over three seasons. J Clin Microbiol. 2005;43:36-40.

Scott PD, Ochola R, Ngama M, Okiro EA, Nokes DJ, Medley GF, Cane PA. Molecular epidemiology of respiratory syncytial virus in kilifi district, Kenia. J Med Virol. 2004;74: 344-54.

Swofford DL. PAUPI. Phylogenetic Analysis Using Parsimony and others Methods. Version 4. Sunderland (Massachusett): Sinauer Associates; 1998.

Schimidit AC, Couch RB, Galasso GJ, Hayden FG, Mills J, Murphy BR, Chanock RM. Current research on respiratory viral infections: Third Internacional Symposium. Antiviral Res. 2001. 50:157-96.

Seki K, Tsutsumi H, Ohsaki M, Kamasaki H, Chiba S. Genetic Variability of Respiratory Syncytial Virus Subgroup a Strain in 15 Successive Epidemics in one City. J Med Virol. 2001; 64:374-80.

Silva LHA, Spilki FR, Riccetto AGL, Almeida RS, Baracat ECE, Arns CW. Genetic variability in the $G$ protein gene of human respiratory syncytial virus isolated from the Campinas metropolitan region, Brazil. J Med Virol. 2008;1653-60.

Sullender WM, Mufson MA, Anderson LJ, Wertz GW. Genetic Diversity of the Attachment Protein of Subgroup B Respiratory Syncytial Virus. J Virol. 1991;65:542534.

Sullender WM. Respiratory Syncytial Virus Genetic and Antigenic Diversity. Clin Microbiol Rev. 2000;13(1):1-15.

Sutmoller F, Ferro ZPA, Asensi MD, Ferreira V, Mazzei IS, Cunha, BL. Etiology of acute respiratory tract infections among children in a combined community and hospital study in Rio de Janeiro. Clin Infec Dis. 1995;20:854-60.

Suto T, Yano N. Ikeda respiratory syncytial virus infection and Its Serologic epidemiology. Am J Epidemiol. 1965;82:211-24.

Takahashi VNO. Correlação entre tipos A e V de vírus respiratório sincicial humano (HRSV) e a gravidade das infecções em crianças [dissertação (mestrado)]. São Paulo: Instituto de Ciências Biomédicas da Universidade de São Paulo; 2001.

Tang RS, Nguyen N, Cheng X, Jin H. Requirement of cysteines and length of the human respiratory syncytial virus M2-1 protein for protein function and virus viability. J Virol. $2001 ; 75: 11328-335$.

Taylor CE, Morrow S, Scott M, Young B, Toms GJ. Comparative Virulence of Respiratory Syncytial Virus subgroups A and B. Lancet. 1989;777-8.

Tekknat KK, Maassab H, Berlin AA, Lincolin PM, Evanoff HL, Kaplam MH, Lukacs NW. Role of Interleukin-12 and Stat-4 in the regulation of airway inflammation and hyperactivity in respiratory syncytial virus infection. Am J Pathol. 2001;159(2):631-8. 
Thomazelli LM. Vigilância epidemiológica de vírus respiratórios humanos em amostras clinicas pela técnica de GeneScan-RT-PCR [dissertação]. São Paulo: Instituto de Ciências biomédicas da Universidade de São Paulo; 2004.

Thomazelli LM, Vieira S, Leal AL, Sousa TS, Oliveira DB, Golono MA et al. Surveillance of eight respiratory viruses in clinical samples of pediatric patients in southeast Brazil. J Pediatr. 2007;83(5):422-8.

Tran TL, Castagné N, Bhella D, Varela PF, Bernard J, Chilmonczk S, et al. The nine Cterminal amino acids of the respiratory syncytial virus protein $\mathrm{P}$ are necessary and sufficient for binding to ribonucleoprotein complexes in which six ribonucleotides are contacted per n protein promoter. J Gen Virol. 2007;88:196-206.

Trento F, Galiano M, Videla C, Carballal G, García-Barreno B, Melero JA, Palomo C. Major changes in the $G$ protein of human respiratory syncytial virus isolates introduced by a duplication of 60 nucleotides. J Gen Virol. 2003;84:3115-20.

Tristram DA, Welliver RC. Respiratory Syncytial Virus. In: Diagnostic Procedure for Viral, Rickettsial and Chamydial Infections. 7 ed. Woshington, DC: American Public Health Associantion; 1996.

van Elden LJ, van Kraaij MG, Nijhuis M, Hendriksen KA, Dekker AW, RozenbergArska M, van Loon AM. Polymerase chain reaction is more sensitive than viral culture and antigen testing for the detection of respiratory viruses in adults with hematological cancer and pneumonia. Clin Infect Dis. 2002;34:177-83.

van Schaik SM, Obot N, Enhorning G, Hintz K, Gross K, Hancock GE, Stack AM, Welliver RC. Role of interferon gamma in the pathogenesis of primary respiratory syncytial virus infection in BALB/c mice. J Med Virol. 2000;62(2);257-66.

van Regenmortel MHV, Fauquet CM, Bishop DHL, Carstens EB, Estes MK, Lemons SM, Maniloff J, Mayo MA, Mcgeoch DJ, Pringle CR, Wickner RB. Virus Taxonomy: The Classification and Nomenclature of Viruses. Seventh Report of the International Committee on Taxonomy of Viruses. San Diego: Academic Press; 2000. p. 525-59.

Varga SM, Wissinger EL, Braciale TJ. The attachment (G) glycoprotein of respiratory syncytial virus contains a single immunodominant epitope that elicits both Th1 and Th2 CD4+ T cell responses. J Immunol. 2000;165:6487-97.

Venter M, Madhi SA, Tiemessen CT, Schoub BD. Genetic Diversity and Molecular Epidemiology of Respiratory Syncytial Virus over four Consecutive Seasons in South Africa: Identification of new Subgroup A and B Genotypes. J Gen Virol. 2001;82:211724.

Ventre K, Randolph AG. Ribavirin for respiratory syncytial virus infection of the lower respiratory tract in infants and young children. Cochrane database Syst Rev. 2004: CD000181. 
Vieira SE, Stewien KE, Queiroz DA, Durigon EL, Török TJ, Anderson LJ, Miyao CR, Hein N, Botosso VF, Pahl MM, Gilio AE, Ejzenberg B, Okay Y. Clinical patterns and seasonal trends in respiratory syncytial virus hos-pitalizations in São Paulo, Brazil. Rev Inst Med Trop São Paulo. 2001;43:125-31.

Vuvojic O, Mills J. Preventive and therapeutic strategies for respiratory syncytial virus infection. Curr Opin Pharmacol. 2001;20:232-55.

Xu Z, Kuang M, Okicki JR, Cramer H, Chaudhary N. Potent inhibition of re4spiratory syncytial virus by combination treatment with $2-5 \mathrm{~A}$ antisense and ribavirin. Antiviral Res. 2004;61:195-206.

Wahab AA, Dawod ST, Raman HM. Clinical characteristics of respiratory syncytial virus infection in hospitalized healthy infants and young children in Qatar. J Trop Pediatr. 2001; 47: 363-6.

Walsh EE, Hruska J. Monoclonal antibodies to respiratory syncytial virus proteins: identication of the fusion protein. J Virol. 1983;47(1):171-7.

Wash EE, Falsey RA. Age related differences in humural immune response to Respiratory syncytial virus infection in adults. J MED Virol. 2004; 73:295-9.

Weinberg GA, Erdman KM, Edwards CB, Hall FJ, Walker MR, Griffin B, Schawart. The bew vaccine surveillance network study group. Superiority of reverse-transcription polymerase chain reaction to conventional viral culture in the diagnosis of acute respiratory tract infections in children. J infect Dis. 2004;189:706-10.

Whitehead SS, Bukreyev A, Teng MN, Firestone CY, St Claire M, Elkins WR, Collins PL, Murphy BR. Recombinant respiratory syncytial virus bearing a deletion of either the NS2 or SH gene is attenuated in chimpanzees. J Virol 1999;73:3438-42

Wyde PR. Respiratory syncytial virus (RSV) disease and prospects for its control. Antiviral Res. 1998;39:63-79.

Welliver RC. Respiratory syncytial virus and other respiratory viruses. Pediatr Infect Dis J. 2003;22(2 Suppl): 6-10.

Zelaya EAC, Petterson CA, Farsgren M, Orvell C, Strannegard O. Respiratory syncytial virus infection in hospitalized patients and healthy children in El Salvador. Am J Trop Med Hyg. 1994;51(5):577-84.

Zhang Y, XuW, Shen K, Xie Z, Sun L, Lu Q, Liu C, Liang G, Beeler JA, Anderson LJ. Genetic variability of group A and B human respiratory syncytial viruses isolated from 3 provinces in China. Arch Virol. 2007;152 (8):1425-34.

Zheng H, Peret TC, Randoph VB, Crowley JC, Anderson LJ. Strain-Specific Reverse Transcriptase PCR Assay: Means to Distinguish Candidate Vaccine from Wilde-Type Strains of Respiratory Syncytial Virus. J Clin Microbiol. 1996;34:334-7.

Zlateva KT, Lemey P, Moesd E, Vandamme AM, Van Ransl M. Molecular evolution and circulation patterns of human respiratory syncytial virus subgroup A: positively 
selected sites in the attachment G glycoprotein. J Virol. 2004;78:4675-83.

Zlateva KT, Lemey P, Moesd E, Vandamme AM, Van Ransl M. Genetic variability and molecular evolution of the human respiratory syncytial virus subgroup $b$ attachament $G$ protein. J Virol. 2005;79:9557-67.

Zlateva KT, Vijgen L, Dekeersmaeker N, Naranjo C, Van Ransl M. Subgroup Prevalence and Genotype Circulation Patterns of Human Respiratory Syncytial Virus in Belgium during Ten Successive Epidemic Seasons. J Clin Microbiol. 2007;45: 3022-30. 
ANEXO A 


\section{ANEXO A}

Grupo de amostras brasileiras geneticamente idênticas para o grupo A nas proteínas $\mathrm{G}$ e $\mathrm{SH}$.

\begin{tabular}{|c|c|c|c|c|}
\hline $\begin{array}{l}\text { Amostra representantes } \\
\text { que figura nas análises }\end{array}$ & Proteína & Grupo & Genótipo & $\begin{array}{c}\text { Amostras que apresentaram } 100 \% \text { de } \\
\text { similaridade }\end{array}$ \\
\hline $\begin{array}{c}1^{\circ} \text { Grupo } \\
\text { GA2BR295_04 }\end{array}$ & G & A & GA2 & $\begin{array}{l}\text { GA2BR111_04; } \quad \text { GA2BR113_04; } \\
\text { GA2BR126_04; GA2BR127_04; GA2BR177_04 } \\
\text { GA2BR199_04; } \quad \text { GA2BR230_04; } \\
\text { GA2BR283_04; GA2BR307_04 }\end{array}$ \\
\hline $\begin{array}{l}2^{\circ} \text { Grupo } \\
\text { GA5BR032_05 }\end{array}$ & G & A & GA5 & $\begin{array}{l}\text { GA5BR035_05; GA5BR052_05; GA5BR058_05 } \\
\text { GA5BR103005; GA5BR131_04; GA5BR138_04 } \\
\text { GA5BR143_04; GA5BR146_04; GA5BR159_04 } \\
\text { GA5BR175_04; GA5BR181_05; GA5BR221_04 } \\
\text { GA5BR222_04; GA5BR237_04; GA5BR253_04 } \\
\text { GA5BR258_04; GA5BR259_04; GA5BR304_04 } \\
\text { GA5BR328_04 }\end{array}$ \\
\hline $3^{\circ}$ Grupo GA5BR105_05 & $\mathrm{G}$ & A & GA5 & GA5BR107_05; GA5BR109_05 \\
\hline $4^{\circ}$ Grupo GA5BR139_04 & $\mathrm{G}$ & A & GA5 & GA5BR198_04 \\
\hline $5^{\circ}$ Grupo GA5BR144_04 & G & A & GA5 & GA5BR154_04 \\
\hline $6^{\circ}$ Grupo GA5BR306_05 & $\mathrm{G}$ & A & GA5 & GA5BR315_05 \\
\hline & G & A & GA2 & $\begin{array}{c}\text { GA2BR084_04; GA2BR128_04; GA2BR158_04 } \\
\text { GA2BR228_04; GA2BR292_05 }\end{array}$ \\
\hline $\begin{array}{l}7^{\circ} \text { Grupo amostras que não tiveram } \\
100 \% \text { de similaridade. }\end{array}$ & G & A & GA5 & $\begin{array}{c}\text { GA5BR039_04; GA5BR077_04; GA5BR099_05 } \\
\text { GA5BR117_04; GA5BR120_04; GA5BR142_04 } \\
\text { GA5BR155_04; GA5BR178_04; GA5BR206_04 } \\
\text { GA5BR224_04; GA5BR225_04; GA5BR233_04 } \\
\text { GA5BR240_04; GA5BR250_04; GA5BR251_04; } \\
\text { GA5BR270_04; GA5BR327_04 }\end{array}$ \\
\hline $\begin{array}{c}1^{\circ} \text { Grupo } \\
\text { GA2BR295_04 }\end{array}$ & SH & A & GA2 & $\begin{array}{c}\text { GA2BR068_04; GA2BR084_04; GA2BR111_04 } \\
\text { GA2BR115_04; GA2BR126_04; GA2BR127_04 } \\
\text { GA2BR128_04; GA2BR158_04; GA2BR177_04 } \\
\text { GA2BR199_04; GA2BR230_04; GA2BR239_04 } \\
\text { GA2BR283_04; GA2BR307_04 }\end{array}$ \\
\hline $\begin{array}{c}2^{\circ} \text { Grupo } \\
\text { GA5BR032_05 }\end{array}$ & $\mathrm{SH}$ & A & GA5 & $\begin{array}{l}\text { GA5BR035_05; GA5BR039_04;GA5BR052_05 } \\
\text { GA5BR058_04; GA5BR077_04; GA5BR099_05 } \\
\text { GA5BR103_05; GA5BR105_05; GA5BR107_05 } \\
\text { GA5BR109_05; GA5BR117_04; GA5BR120_04 } \\
\text { GA5BR131_04; GA5BR138_04; GA5BR143_04 } \\
\text { GA5BR144_04; GA5BR146_04; GA5BR154_04 } \\
\text { GA5BR155_04; GA5BR159_04; GA5BR175_04 } \\
\text { GA5BR178_04; GA5BR181_05; GA5BR206_04 } \\
\text { GA5BR221_04; GA5BR222_04; GA5BR224_04 } \\
\text { GA5BR225_04; GA5BR233_04; GA5BR237_04 } \\
\text { GA5BR250_04; GA5BR251_04; GA5BR253_04 } \\
\text { GA5BR258_04; GA5BR259_04; GA5BR270_04 } \\
\text { GA5BR304_04; GA5BR315_04; GA5BR328_04 }\end{array}$ \\
\hline $3^{\circ}$ Grupo GA5BR139_04 & $\mathrm{SH}$ & A & GA5 & GA5BR198_04 \\
\hline \multirow[b]{2}{*}{$\begin{array}{l}7^{\circ} \text { Grupo amostras que não tiveram } \\
100 \% \text { de similaridade. }\end{array}$} & $\mathrm{SH}$ & $\mathrm{A}$ & GA2 & GA2BR113_04; GA2BR228_04; GA2BR292_04 \\
\hline & SH & A & GA5 & $\begin{array}{c}\text { GA5BR142_04; GA5BR240_04; GA5BR306_05 } \\
\text { GA5BR327_04 }\end{array}$ \\
\hline
\end{tabular}


ANEXO B 


\section{ANEXO B}

Grupo de amostras brasileiras geneticamente idênticas para o grupo B nas proteínas G e $\mathrm{SH}$

\begin{tabular}{|c|c|c|c|c|}
\hline $\begin{array}{l}\text { Amostras } \\
\text { representantes que } \\
\text { figura nas análises }\end{array}$ & Proteína & Grupo & Genótipo & $\begin{array}{c}\text { Amostras que apresentaram } 100 \% \text { de } \\
\text { similaridade }\end{array}$ \\
\hline $\begin{array}{c}1^{\circ} \text { grupo } \\
\text { BINSBR321_05 }\end{array}$ & $\mathrm{G}$ & B & BI-like & $\begin{array}{l}\text { BINSBR022_05; BINSBR027_05; BINSBR037_05 } \\
\text { BINSBR039_05; BINSBR053_05; BINSBR111_05 } \\
\text { BINSBR154_05; BINSBR178_05; BINSBR179_05 } \\
\text { BINSBR184_05; BINSBR200_05; BINSBR210_05 } \\
\text { BINSBR215_05; BINSBR217_05; BINSBR233_05 } \\
\text { BINSBR252_05; BINSBR271_05; BINSBR274_05 } \\
\text { BINSBR282_05; BINSBR290_05; BINSBR305_05 }\end{array}$ \\
\hline $2^{\circ}$ grupo BINSBR301_05 & G & B & BI-like & BINSBR041_05 \\
\hline $3^{\circ}$ grupo BINSBR100_05 & G & B & BI-like & BINSBR149_05; BINSBR158_05; BINSBR242_05 \\
\hline $4^{\circ}$ grupo BINSBR195_05 & $\bar{G}$ & $\mathrm{~B}$ & BI-like & BINSBR222_05; BINSBR249_05 \\
\hline $5^{\circ}$ grupo GB3BR223_05 & G & B & GB3 & GB3BR229_05 \\
\hline $6^{\circ}$ grupo SAB1BR082_04 & G & B & SAB1 & SAB1BR303_04 \\
\hline $7^{\circ}$ grupo SAB3BR073_04 & G & B & SAB3 & SAB3BR129_04; SAB1BR049_05; SAB3BR245_04 \\
\hline $\begin{array}{l}8^{\circ} \text { Grupo amostras que não } \\
\text { tiveram } 100 \% \text { de } \\
\text { similaridade. }\end{array}$ & G & B & BI-like & $\begin{array}{l}\text { BINSBR040_05; BINSBR056_05; BINSBR093_04 } \\
\text { BINSBR115_05; BINSBR157_04; BINSBR188_05 } \\
\text { BINSBR216_05; BINSBR221_05; BINSBR236_05 } \\
\text { BINSBR293_05; BINSBR307_05 }\end{array}$ \\
\hline $1^{\circ}$ grupo BINSBR022_05 & SH & B & BI-like & $\begin{array}{l}\text { BINSBR027_05; BINSBR037_05; BINSBR039_05 } \\
\text { BINSBR040_05; BINSBR053_05; BINSBR111_05 } \\
\text { BINSBR149_05; BINSBR154_05; BINSBR158_05 } \\
\text { BINSBR179_05; BINSBR188_05; BINSBR200_05 } \\
\text { BINSBR210_05; BINSBR222_05; BINSBR236_05 } \\
\text { BINSBR242_05; BINSBR252_05; BINSBR282_05 } \\
\text { BINSBR293_05; BINSBR305_05; BINSBR307_05 }\end{array}$ \\
\hline $2^{\circ}$ grupo BINSBR056_05 & SH & B & BI-like & $\begin{array}{c}\text { BINSBR093_04; BINSBR115_05; BINSBR157_05 } \\
\text { BINSBR178_05; BINSBR215_05; BINSBR216_05 } \\
\text { BINSBR217_05 }\end{array}$ \\
\hline $3^{\circ}$ grupo GB3BR223_05 & $\mathrm{SH}$ & $\mathrm{B}$ & GB3 & GB3BR229_05 \\
\hline $4^{\circ}$ grupo SAB1BR082_04 & $\mathrm{SH}$ & B & SAB1 & SAB1BR303_04 \\
\hline $5^{\circ}$ grupo SAB3BR073_04 & SH & B & SAB3 & SAB3BR129_04 \\
\hline $6^{\circ}$ grupo BINSBR195_04 & SH & $\mathrm{B}$ & BI-like & BINSBR249_04 \\
\hline $\begin{array}{l}7^{\circ} \text { Grupo amostras que não } \\
\text { tiveram } 100 \% \text { de } \\
\text { similaridade. }\end{array}$ & SH & B & BI-like & $\begin{array}{c}\text { BINSBR041_05; BINSBR102_04; BINSBR102_05 } \\
\text { BINSBR184_05; BINSBR233_05; BINSBR271_05 } \\
\text { BINSBR274_05; BINSBR290_05; BINSBR301_05 } \\
\text { BINSBR321_05; GB3BR160_05; SAB1BR049_05 } \\
\text { SAB3BR245_04 }\end{array}$ \\
\hline
\end{tabular}


ANEXO C 


\section{ANEXO C}

Amostras com identificação do Genbank para o grupo A.

\begin{tabular}{|c|c|c|c|}
\hline $\begin{array}{c}\text { Nome de origem das } \\
\text { amostras. }\end{array}$ & Nome para genbank & tipo & $\begin{array}{c}\mathrm{N}^{\circ} \text { de acesso no } \\
\text { Genbank }\end{array}$ \\
\hline GA2BR068_2004 & BR04_RSVGDN01 & A & 109312 \\
\hline GA2BR084_2004 & BR04_RSVGDN02 & A & 109313 \\
\hline GA2BR111_2004 & BR04_RSVGDN03 & $\mathrm{A}$ & 109314 \\
\hline GA2BR113_2004 & BR04_RSVGDN04 & A & 109315 \\
\hline GA2BR115_2004 & BR04_RSVGDN05 & A & 109316 \\
\hline GA2BR126_2004 & BR04_RSVGDN06 & $\mathrm{A}$ & 109317 \\
\hline GA2BR127_2004 & BR04_RSVGDN07 & A & 109318 \\
\hline GA2BR128_2004 & BR04_RSVGDN08 & A & 109319 \\
\hline GA2BR158_2004 & BR04_RSVGDN09 & $\mathrm{A}$ & 109320 \\
\hline GA2BR177_2004 & BR04_RSVGDN10 & A & 109321 \\
\hline GA2BR199_2004 & BR04_RSVGDN11 & A & 109322 \\
\hline GA2BR228_2004 & BR04_RSVGDN12 & $\mathrm{A}$ & 109323 \\
\hline GA2BR230_2004 & BR04_RSVGDN13 & $\mathrm{A}$ & 109324 \\
\hline GA2BR239_2004 & BR04_RSVGDN14 & A & 109325 \\
\hline GA2BR283_2004 & BR04_RSVGDN15 & $\mathrm{A}$ & 109326 \\
\hline GA2BR292_2005 & BR05_RSVGDN16 & $\mathrm{A}$ & 109327 \\
\hline GA2BR295_2004 & BR04_RSVGDN17 & A & 109328 \\
\hline GA2BR307_2004 & BR04_RSVGDN18 & $\mathrm{A}$ & 109329 \\
\hline GA2BR032_2005 & BR05_RSVGDN19 & A & 109330 \\
\hline GA2BR035_2005 & BR05_RSVGDN20 & A & 109331 \\
\hline GA2BR039_2004 & BR04_RSVGDN21 & A & 109332 \\
\hline GA2BR052_2005 & BR05_RSVGDN22 & $\mathrm{A}$ & 109333 \\
\hline GA2BR058_2004 & BR04_RSVGDN23 & $\mathrm{A}$ & 109334 \\
\hline GA2BR077_2004 & BR04_RSVGDN24 & $\mathrm{A}$ & 109335 \\
\hline GA2BR083_2004 & BR04_RSVGDN25 & A & 109336 \\
\hline GA2BR099_2005 & BR05_RSVGDN26 & A & 109337 \\
\hline GA2BR103_2005 & BR05_RSVGDN27 & A & 109338 \\
\hline GA2BR105_2005 & BR05_RSVGDN28 & $\mathrm{A}$ & 109339 \\
\hline GA2BR107_2005 & BR05_RSVGDN29 & $\mathrm{A}$ & 109340 \\
\hline GA2BR109_2005 & BR05_RSVGDN30 & $\mathrm{A}$ & 109341 \\
\hline GA2BR117_2004 & BR04_RSVGDN31 & A & 109342 \\
\hline GA2BR120_2004 & BR04_RSVGDN32 & A & 109343 \\
\hline GA2BR131_2004 & BR04_RSVGDN33 & $\mathrm{A}$ & 109344 \\
\hline GA2BR138_2004 & BR04_RSVGDN34 & $\mathrm{A}$ & 109345 \\
\hline GA2BR139_2004 & BR04_RSVGDN35 & $\mathrm{A}$ & 109346 \\
\hline GA2BR142_2004 & BR04_RSVGDN36 & $\mathrm{A}$ & 109347 \\
\hline GA2BR143_2004 & BR04_RSVGDN37 & A & 109348 \\
\hline GA2BR144_2004 & BR04_RSVGDN38 & A & 109349 \\
\hline GA2BR146_2004 & BR04_RSVGDN39 & A & 109350 \\
\hline
\end{tabular}




\begin{tabular}{|l|l|l|l|}
\hline GA2BR154_2004 & BR04_RSVGDN40 & A & 109351 \\
\hline GA2BR155_2004 & BR04_RSVGDN41 & A & 109352 \\
\hline GA2BR159_2004 & BR04_RSVGDN42 & A & 109353 \\
\hline GA2BR175_2004 & BR04_RSVGDN43 & A & 109354 \\
\hline GA2BR178_2004 & BR04_RSVGDN44 & A & 109355 \\
\hline GA2BR181_2005 & BR05_RSVGDN45 & A & 109356 \\
\hline GA2BR198_2004 & BR04_RSVGDN46 & A & 109357 \\
\hline GA2BR206_2004 & BR04_RSVGDN47 & A & 109358 \\
\hline GA2BR221_2004 & BR04_RSVGDN48 & A & 109359 \\
\hline GA2BR222_2004 & BR04_RSVGDN49 & A & 109360 \\
\hline GA2BR224_2004 & BR04_RSVGDN50 & A & 109361 \\
\hline GA2BR225_2004 & BR04_RSVGDN51 & A & 109362 \\
\hline GA2BR233_2004 & BR04_RSVGDN52 & A & 109363 \\
\hline GA2BR237_2004 & BR04_RSVGDN53 & A & 109364 \\
\hline GA2BR240_2004 & BR04_RSVGDN54 & A & 109365 \\
\hline GA2BR250_2004 & BR04_RSVGDN55 & A & 109366 \\
\hline GA2BR251_2004 & BR04_RSVGDN56 & A & 109367 \\
\hline GA2BR253_2004 & BR04_RSVGDN57 & A & 109368 \\
\hline GA2BR258_2004 & BR04_RSVGDN58 & A & 109369 \\
\hline GA2BR259_2004 & BR04_RSVGDN59 & A & 109370 \\
\hline GA2BR270_2004 & BR04_RSVGDN60 & A & 109371 \\
\hline GA2BR304_2004 & BR04_RSVGDN61 & A & 109372 \\
\hline GA2BR306_2005 & BR05_RSVGDN62 & A & 109373 \\
\hline GA2BR315_2005 & BR05_RSVGDN63 & A & 109374 \\
\hline GA2BR327_2004 & BR04_RSVGDN64 & A & 109375 \\
\hline GA2BR328_2004 & BR04_RSVGDN65 & A & 109376 \\
\hline
\end{tabular}


ANEXO D 


\section{ANEXO D}

Amostras com identificação do Genbank para o grupo B.

\begin{tabular}{|c|c|c|c|}
\hline $\begin{array}{c}\text { Nome de origem das } \\
\text { amostras }\end{array}$ & Nome para Genbank & tipo & $\begin{array}{c}\mathrm{N}^{\mathrm{o}} \mathrm{de} \\
\text { acesso no } \\
\text { Genbank }\end{array}$ \\
\hline BINSBR022_2005 & BR05_RSVGDN66 & $\mathrm{B}$ & 109377 \\
\hline BINSBR027_2005 & BR05_RSVGDN67 & B & 109378 \\
\hline BINSBR037_2005 & BR05_RSVGDN68 & B & 109379 \\
\hline BINSBR039_2005 & BR05_RSVGDN69 & $\mathrm{B}$ & 109380 \\
\hline BINSBR040_2005 & BR05_RSVGDN70 & B & 109381 \\
\hline BINSBR041_2005 & BR05_RSVGDN71 & B & 109382 \\
\hline BINSBR053_2005 & BR05_RSVGDN72 & $\mathrm{B}$ & 109383 \\
\hline BINSBR056_2005 & BR05_RSVGDN73 & $\mathrm{B}$ & 109384 \\
\hline BINSBR093_2004 & BR04_RSVGDN74 & $\mathrm{B}$ & 109385 \\
\hline BINSBR100_2005 & BR05_RSVGDN75 & $\mathrm{B}$ & 109386 \\
\hline BINSBR102_2005 & BR05_RSVGDN76 & B & 109387 \\
\hline BINSBR111_2005 & BR05_RSVGDN77 & B & 109388 \\
\hline BINSBR115_2005 & BR05_RSVGDN78 & $\mathrm{B}$ & 109389 \\
\hline BINSBR149_2005 & BR05_RSVGDN79 & $\mathrm{B}$ & 109390 \\
\hline BINSBR154_2005 & BR05_RSVGDN80 & $\mathrm{B}$ & 109391 \\
\hline BINSBR157_2004 & BR04_RSVGDN81 & $\mathrm{B}$ & 109392 \\
\hline BINSBR158_2005 & BR05_RSVGDN82 & $\mathrm{B}$ & 109393 \\
\hline BINSBR178_2005 & BR05_RSVGDN83 & $\mathrm{B}$ & 109394 \\
\hline BINSBR179_2005 & BR05_RSVGDN84 & $\mathrm{B}$ & 109395 \\
\hline BINSBR184_2005 & BR05_RSVGDN85 & $\mathrm{B}$ & 109396 \\
\hline BINSBR188_2005 & BR05_RSVGDN86 & $\mathrm{B}$ & 109397 \\
\hline BINSBR195_2005 & BR05_RSVGDN87 & B & 109398 \\
\hline BINSBR200_2005 & BR05_RSVGDN88 & B & 109399 \\
\hline BINSBR210_2005 & BR05_RSVGDN89 & $\mathrm{B}$ & 109400 \\
\hline BINSBR215_2005 & BR05_RSVGDN90 & $\mathrm{B}$ & 109401 \\
\hline BINSBR216_2005 & BR05_RSVGDN91 & B & 109402 \\
\hline BINSBR217_2005 & BR05_RSVGDN92 & $\mathrm{B}$ & 109403 \\
\hline BINSBR221_2005 & BR05_RSVGDN93 & B & 109404 \\
\hline BINSBR222_2005 & BR05_RSVGDN94 & B & 109405 \\
\hline BINSBR233_2005 & BR05_RSVGDN95 & $\mathrm{B}$ & 109406 \\
\hline BINSBR236_2005 & BR05_RSVGDN96 & $\mathrm{B}$ & 109407 \\
\hline BINSBR242_2005 & BR05_RSVGDN97 & $\mathrm{B}$ & 109408 \\
\hline BINSBR249_2005 & BR05_RSVGDN98 & B & 109409 \\
\hline BINSBR252_2005 & BR05_RSVGDN99 & B & 109410 \\
\hline BINSBR271_2005 & BR05_RSVGDN100 & $\mathrm{B}$ & 109411 \\
\hline BINSBR282_2005 & BR05_RSVGDN101 & $\mathrm{B}$ & 109412 \\
\hline BINSBR293_2005 & BR05_RSVGDN102 & $\mathrm{B}$ & 109413 \\
\hline BINSBR301_2005 & BR05_RSVGDN103 & $\mathrm{B}$ & 109414 \\
\hline BINSBR305_2005 & BR05_RSVGDN104 & B & 109415 \\
\hline BINSBR307_2005 & BR05_RSVGDN105 & B & 109416 \\
\hline
\end{tabular}




\begin{tabular}{|c|c|c|c|}
\hline BINSBR321_2005 & BR05_RSVGDN106 & B & 109417 \\
\hline GB3BR160_2005 & BR05_RSVGDN107 & B & 109418 \\
\hline GB3BR223_2005 & BR05_RSVGDN108 & B & 109419 \\
\hline GB3BR229_2005 & BR05_RSVGDN109 & B & 109420 \\
\hline SAB1BR049_2005 & BR05_RSVGDN110 & B & 109421 \\
\hline SAB1BR303_2004 & BR04_RSVGDN111 & B & 109422 \\
\hline SAB3BR073_2004 & BR04_RSVGDN112 & B & 109423 \\
\hline SAB3BR129_2004 & BR04_RSVGDN113 & B & 109424 \\
\hline SAB3BR245_2004 & BR04_RSVGDN114 & B & 109425 \\
\hline
\end{tabular}


ANEXO E 


\section{ANEXO E}

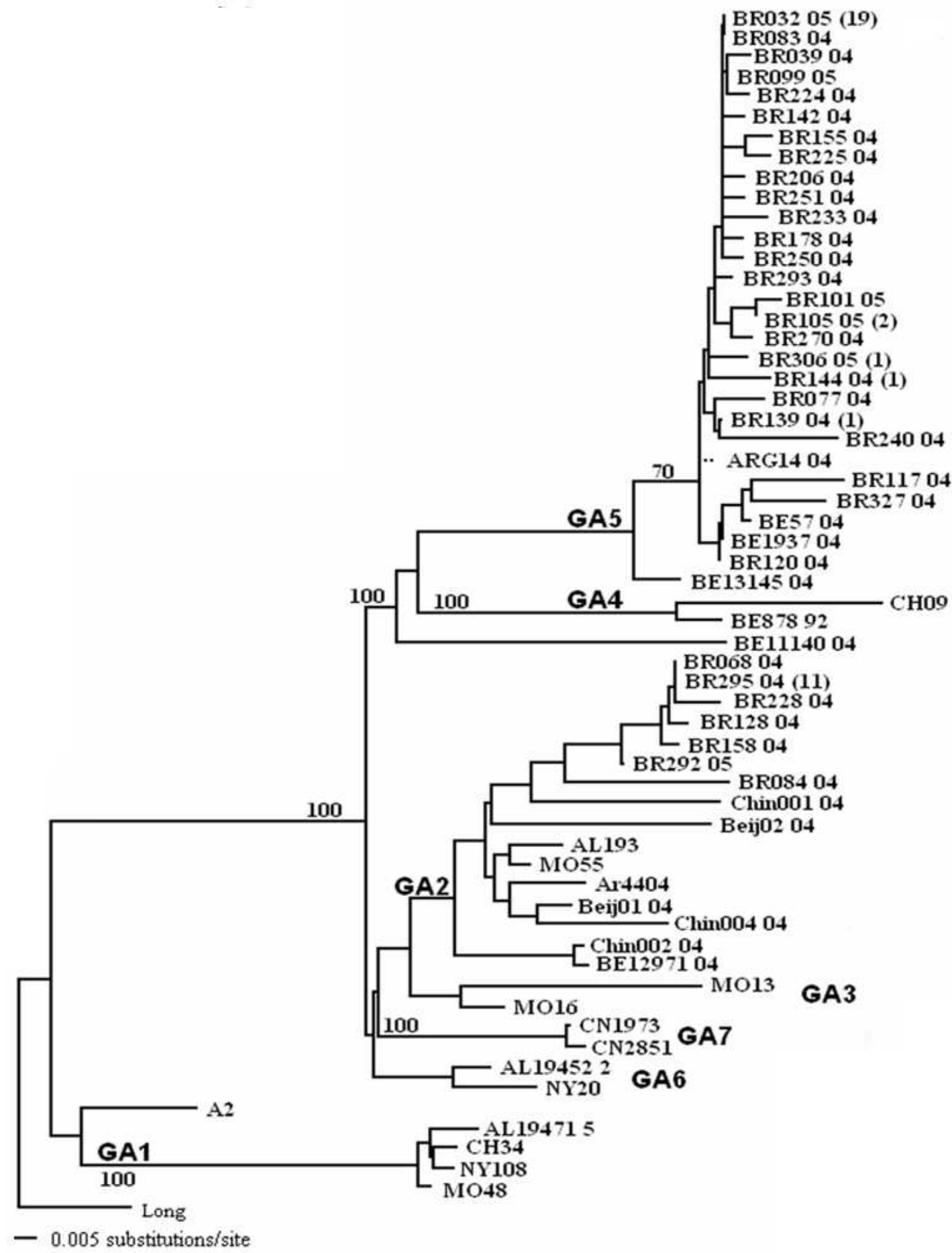

Árvore filogenética do grupo A do HRSV obtida pelo metodo Maximum Likelihood (segunda região variável do genecodificador da glicoproteína G, G2 com 270. Os números internos representam os valores do bootstrap representados sobre os nós (500 replicas). E a classificação dos genótipos são indicados no inicio dos ramos. As sequencias para comparação foram adquiridas . no GenBank. United States (TX, Texas; AL, Alabama; NY, New York; MO, Missouri; CH, Rochester, NewYork); Canada (CN) SA, Soweto, South Africa; Ag, Agincourt, South Africa; Mozambique (Moz) [21]; B1; WV, West Virginia, SWED 8-60; Sel, Seoul, Vir, Virginia; NMex, New Mexico; Mas, Massachussets; SW, Sweden;Mon, Montevideo; Mad, Madrid; Zar, Zaragoza; S, Sapporo, Japan Os números entre parenteses significam o número de amostras idênticas. 
ANEXO F 


\section{ANEXO F}

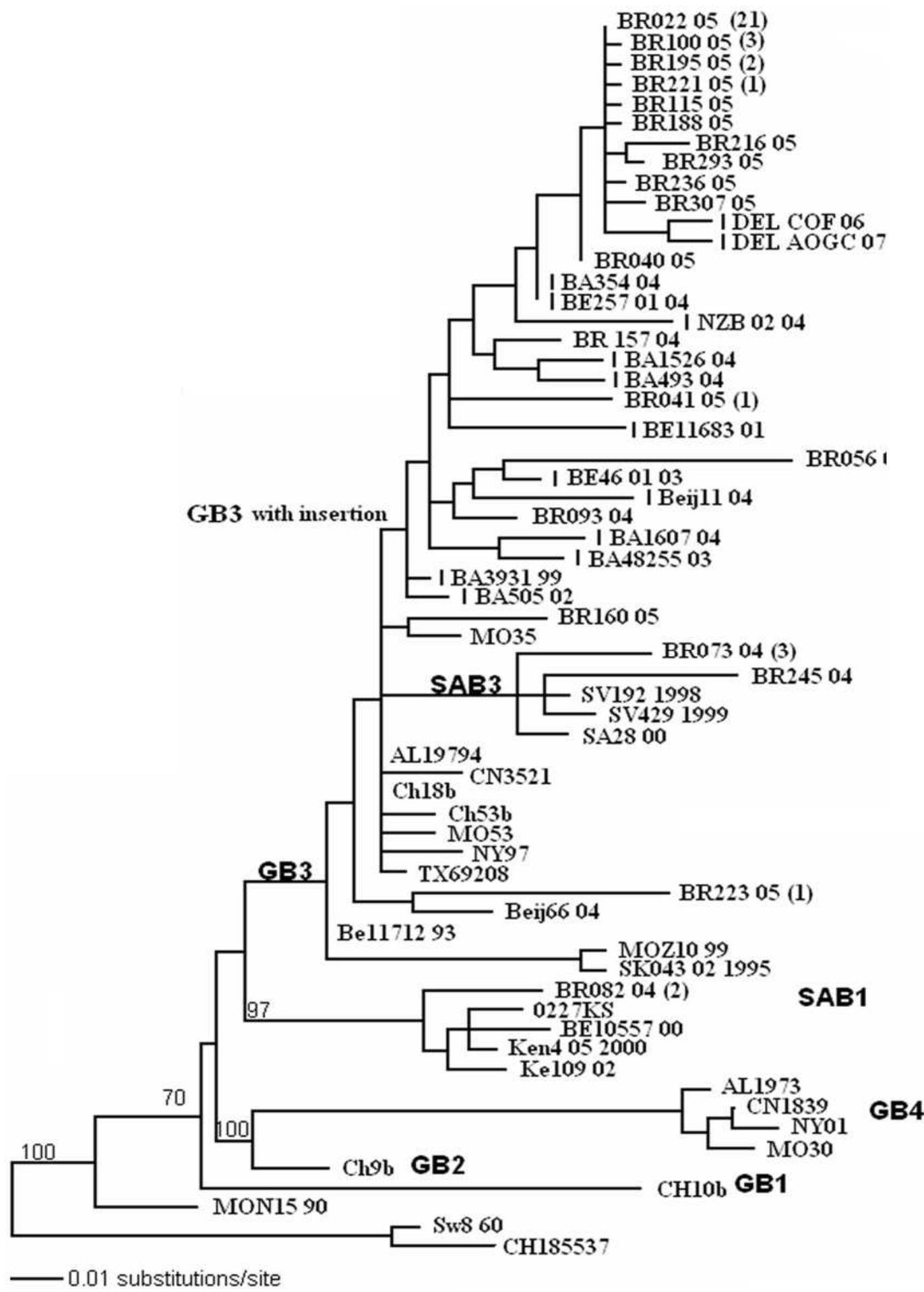

Árvore filogenética do grupo B do HRSV obtida pelo metodo Maximum Likelihood (segunda região variável do gene codificador da glicoproteína G, G2 com 270. Os números internos representam os valores do bootstrap representados sobre os nós (500 replicas). E a classificação dos genótipos são indicados no inicio dos ramos. As sequencias para comparação foram adquiridas . no GenBank. United States (TX, Texas; AL, Alabama; NY, New York; MO, Missouri; CH, Rochester, NewYork); Canada (CN) SA, Soweto, South Africa; Ag, Agincourt, South Africa; Mozambique (Moz) [21]; B1; WV, West Virginia, SWED 8-60; Sel, Seoul, Vir, Virginia; NMex, New Mexico; Mas, Massachussets; SW, Sweden;Mon, Montevideo; Mad, Madrid; Zar, Zaragoza; S, Sapporo, Japan Os números entre parenteses significam o número de amostras idênticas. 